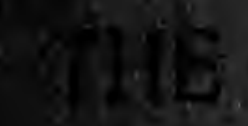

\title{
COMMONWEAL
}

(*) * STUDY OF THE FEDERAL SYSTEM OF POLITICAL ECONOMY 


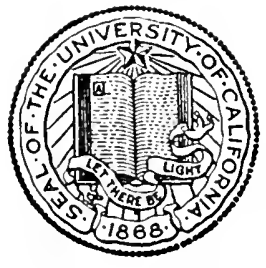

THE LIBRARY

OF

THE UNIVERSITY

OF CALIFORNIA

LOS ANGELES 



\section{THE COMMONWEAL}


, 


\section{THE COMMONWEAL}

A STUDY OF THE FEDERAL SYSTEM OF POLITICAL ECONOMY

BY

ALFRED P. HILLIER, B.A., M.D.

"Hear, for thy children speak from the uttermost parts of the sea"

-Kipling

LONGMANS, GREEN, AND CO.

39 PATERNOSTER ROW, LONDON

NEW YORK, BOMBAY, AND CALCUTTA

1909 
2

7

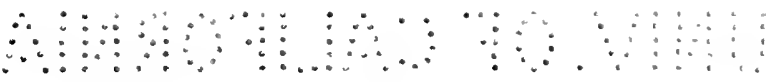

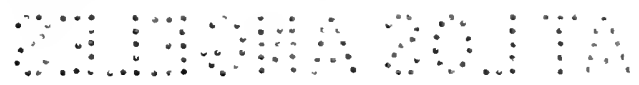
$\because \because \therefore \because \because \vdots \vdots$ 


\section{PREFACE.}

At a time when the proper understanding of certain problems in Political Economy is of more profound moment to the British Empire than perhaps at any other juncture in its history, it is little short of a calamity that issues-the satisfactory determination of which depends upon an unimpassioned and rational study of this subject-should have been swept into the seething vortex of party political controversy.

A further difficulty with which any writer is confronted to-day is the vast field over which the subject may be pursued, and the difficulty of deciding what portions of it to deal with, and what portions to avoid.

For my own part I have attempted this formidable task only after visiting the United States, Germany, and some of the Colonies chiefly concerned; and, after endeavouring to study, so far as was practicable, the fiscal systems in vogue on the spot. I have endeavoured to write a book which practical men of affairs may find time to 
read, and which, therefore, has of necessity been a short rather than a long one.

I have not attempted to traverse all the ground covered by writers on the "Principles of Political Economy," but merely to deal with certain of these "Principles" as enunciated by various writers of the British laisser-faire school, which have influenced for many years the judgment and administration of politicians in dealing with international trade.

The endeavour to trace the effect of certain historic incidents and levelopments on the fiscal systems of different countries, has led me to the conclusion, that, to suppose the expediency of the fiscal policy of any country turns on an Academic controversy as to the abstract merits of Protection and Free Trade, is misleading.

To hold such a view is to misapprehend the nature both of politics and economics. Free Trade is, as a rule, a privilege to the consumer. Protection, on the other hand, has often been held to be a national necessity, and, though less attractive to that hypothetic entity, the consumer uninterested in the industries of his country, is, in certain cases, an advantage and a privilege to the producer. To balance conflicting interests, to determine equitably the allotment of these privileges, so as to obtain the maximum of advantage to the well-being of the State, should be one of the chief arts of Political Economy. 
In the following pages the manner in which certain great federations have secured to their own citizens many of the advantages of Free Trade over large areas, more or less conserved by an outer wall of Tariffs, will be considered.

The sub-title of the book has been chosen as one which appears to be fairly descriptive of a system already in vogue in certain countries, and a modification of which is now under consideration for the British Empire.

\author{
Markyate Cell, \\ Near Dunstable, \\ HERTFORDSHIRE.
}





\title{
CONTENTS.
}

\author{
CHAPTER I.
}

The Writers and Systems

Political Economy-Its definition and function-The views of John Stuart Mill, Adam Smith, List and others-The cosmopolitan ideal-Cosmopolitical Economy-Economic lawsJevons-Copartnership.

\section{CHAPTER II.}

LAISSEZ FAIRE • . . . . . . . . .

Restraints on manufacture in 17 th and 18th centuries-Corn Laws-Limits of the laissez-faire principle-Infringements of the principle-Its application in exchange alowe absolute - Labour protected-Free importation of products of foreign sweated labour-Application of policy in India and Egypt -Modern departures from principle even with importsPredictions of laissez-faire writers, Adam Smith, Mill and Cobden-Natural Protection -Effect of free imports on agriculture-Contrast betwcen the predictions of the laissezfaire schoolmen and of List.

CHAPTER III.

Some Economic Fallacifs . . . . . . . .

Do imports balance exports?-The views of Mill, Farrer, the Fiscal Blue Book, and Lord Avebury-Sources of importing 
power otlicr than exports - No necessary or constant relation between imports and exports of commoditiesCharacter and extent of each must be studied separately -Effect of the suggestio falsi is to stifle discussion and paralyse action-The degradation of industry-Instances of erroneous conclusions arrived at by Lord Farrer and Lord Avebury as to the effect of imports on our exportsGoods not necessarily paid for by goods-Foreign investments - Their magnitude and influence on imports Displacement of British labour-Professor Marshall and change of employment-Capital and labour-The incidence of the burden of import duties under different conditious-Mr. Deakin on import duties-RecapitulationThe alternatives before us.

CHAPTER IV.

America and Protection . . . . . . . .

Alexander Hamilton-The problems before him-American influence upon List-The fiscal system an instrument of Federation in the United States and Germany-The Constitution of the United States - Hamilton's Report on Manufactures-The attraction of foreign capital and labour - Symmetrical national development - Lord Avebury condemus Protection in America-His alternative considered-Hamilton's condition for acceptance of Free Trade-Universal Free Trade-Mr. A. Mosely's Memorandum on American Tariffs-Remarkable progress in steel and cotton industries-Could better results have been obtained under policy of laissez faive?

\section{CHAPTER V.}

Germany and Her Custons Union . . . . . .

The Holy Roman Empire-Modern German Empire-Its Federal character-The wars of Prussia-The Zollverein an instrument of Federation-List's National System of Political Economy-His estimate of England's position in 1844-Free Trade in Germany-The Continental blockade -The work of the Zollverein-Estimates of List and Mill 
on effects of Protection in America compared-Bismarck's Free Trade era-His return to Protection-State Workmen's Insurance-Emigration from Germany and Great Britain -Socialism-Universal military training.

\section{CHAPTER VI.}

Great Britain before Free Trade . . . . . .

The industrial development of England-Sheep-raising-WoolWoollen manufactures-Early measures of Protection-The cotton industry-The Methuen Treaty, 1703-The views of Adam Smith and List on the effect of this Treaty-Shipping and Navigation Laws-If Protection be desirable for infant industries, may it not be so for injured industries?

\section{CHAPTER VII.}

Great Britain's Free Trade Era . . . . .

Free Trade policy of England defined-Its expediency-Cobden and Bright on the Corn Laws-First half of the Free Trade era-Foreign rivals in the forties-Second half of Free Trade era-Industrial position-Injured industries-NLotor industry - Woollen manufactures-Shipbuilding-CottonThe wealth of England not necessarily an index to success of manufactures - The attractions of England as a place of residence-Great value of British Home Market-British wealth and British industry are things apart-Investment abroad-The mazy abstractions of the President of the Board of Trade-Analysis of a foreign investment-Unsatisfactory nature of our trade with Germany-The calamity of unemployment-Producer must be considered with the consumer-Protected labour and free imports-Objections to a Tariff-Bismarck on the British Free Trade era.

\section{CHAPTER VIII.}

The Colonies and India

The altermatives-The fate of small States-The great Federal instrument-Preference-Free Trade and Disintegration- 
Universal Peace--The bygone forebodings of Lord Morley Further miscalculations-March of events forward to Federation, not backward to separation-A Customs Union -Colonial fiscal systems vary, all have one fcature in common, the taxation of imports - Three sets of proposals on Preference-The fiscal system of India-British objections to Preference considered-.Free Food fallacy-England an obstacle to Frcer Trade-Most-favoured Nation treatmentFüchs on the Trade Policy of Great Britain-Closer union essential to the Empire-Has Free Trade been carried too far?-Change must come "soon, or for ever too late"Füchs' warning to Germany-The advantages of Preference-The goal a federated world State.

\section{CHAPTER IX.}

\section{Democracy and Empire}

The Federal Movement-Colonial Nationalism-The French Canadians and Dutch South Africans-The spirit of local patriotism a strength, not a weakness-Empire and Liberty -The Dual Empire-Self-governing and governed-One democracy cannot dictate to another-Flammantia monia Mundi.

APPENDICES.

I. State Insurance for Workmen in Germany . . . 151

II. The Navigation Act $. \quad . \quad . \quad . \quad . \quad . \quad . \quad$. 157 


\section{CHAPTER I.}

\section{THE WRITERS AND SYSTEMS.}

Political Economy-Its definition and function-The views of John Stuart Mill, Adam Smith, List, and others-The cosmopolitan ideal-Cosmopolitical Economy-Economic laws-Jevons.

THeRe is an Eastern proverb which says, "The altarcloth of one æon is the doormat of the next". The significance of this utterance will appeal to the student of history and theology. It contains also a warning to the student of the exact sciences; but for workers in those branches of research and endeavour on the path of knowledge which by common consent are described as being within the category of science, but to which the epithet "exact" is not usually permitted, this cynical observation will appear to have a special meaning.

Political Economy has been called the Dismal Science, and doubtless not without cause. And yet, however abstruse, and even obscure, writings on this subject may sometimes be, and however imperfect as science, there can be no doubt that Political Economy does at least endeavour to deal in a rational spirit of inquiry with the material and practical interests of mankind.

In the words of John Stuart Mill, a gifted and attractive author, "Writers on Political Economy profess "

${ }^{1}$ John Stuart Mill, Principles of Political Economy. 
to teach, or to investigate, the nature of Wealth and the laws of its production and distribution, including, directly or remotely, the operation of all the causes by which the condition of mankind, or of any society of human beings, in respect to this universal object of human desire, is made prosperous or the reverse. Not that any treatise on Political Economy can discuss or even enumerate all these causes; but it undertakes to set forth as much as is known of the laws and principles according to which they operate."

In this definition of the aspirations of Political Economists, the claims of Political Economy to be regarded as a science-as distinguished from other branches of political literature-are suggested in sufficiently modest terms, while Wealth as the main object of its teaching is avowed in words which are brief and unmistakable.

But a perusal of some of the older writers on the subject, especially of the two great classics Adam Smith and List, does raise the question whether this conception of Political Economy is not somewhat narrow. In the minds of both of them, as evidenced in their writings, there were undoubtedly bound up with the subject the ideas of national stability and of power, developing simultaneously and as it were co-ordinately with Wealth. It is in this sense that Adam Smith in his Wealth of Nations addressed himself to a consideration of the Navigation Act. After recapitulating the principal dispositions of this Act (see Appendix) he adds, "The Act of Navigation is not favourable to foreign commerce or to the growth of that opulence which can arise from it." . . . "As defence, however, is of much more importance than opulence, the Act of Navigation is perhaps the wisest of all the commercial regulations of England." The counsel here given recalls in a forcible manner the ob- 
servation addressed by Solon to Crosus: "If a man with better iron than you should meet you, he will be master of all this gold".

In List's great work, A National System of Political Economy, the national spirit predominates in a still greater measure. List wrote with an avowed purpose and that purpose a political one. And he enjoys the distinction of having advocated a commercial and imperial policy which has been adopted, developed, and maintained by his country with the greatest success. List was the intellectual founder of the German Zollverein, and an able and consistent advocate of that consolidation of Imperial Germany which grew out of the Zollverein policy. In dealing with the more purely theoretical aspects of Political Economy about which not only are opponents not agreed, but with regard to which, if we may cite so high a modern authority as Professor W. J. Ashley, they frequently fail to understand each other, List displays as acute, practical and lucid an insight as any of his more subtle doctrinaire rivals. The different points of view from which these two great economists regarded their subject is fairly well expressed in the titles chosen for their books. To Adam Smith, Wealth appeared an object in whose train most other desirable national objects would naturally follow; to List national productive power of an abiding character was the essential complement of Wealth, a complement for the attainment of which special national efforts must be directed, and without which Wealth might be only an illusory and temporary form of national well-being.

Adam Smith was in many respects under the influence of his immediate predecessors in the field of Political Economy-the French Economists. Of these 
Quesnay and Dupont de Nemours were the authors of a work entitled: Physiocratic, ou du Gouvernement le plus avantageux an Genre Humain. In spite of the rivalries and wars around them, these authors refused to recognise that the human race was still unfortunately not united into one happy family, and that until that moment arrived public economy must continue to be for every separate nation a national and not a cosmopolitan economy. Another French writer of this period, Gournay, addressed himself to the task of vindicating the freedom of industries and commerce from any form of restriction or restraint. And he it was who first introduced into the literature of Economics that expression fraught with so much both of good and of evil-laissez faire.

It is in conformity with the teachings of this French school that Adam Smith urges that all restrictions on imports, imposed on behalf of the internal industries of a country, are necessarily impolitic; and that to attain the maximum of national prosperity we simply have to follow the maxim of letting things alone (laissez aller and laisser faire).

It is true Adam Smith subordinated the academician to the patriot as in his attitude on the Navigation Act already referred to. But his main object was, as List very ably points out, to prove, as Quesnay endeavoured to prove before him, that "political or national economy must be replaced by cosmopolitical or world-wide economy". Such a scheme involves the assumption of a world permanently at peace, practically in accord on all the great questions affecting the material welfare of different nations and finally following a system of universal Free Trade. In fact it would almost appear to assume in the nations of the world an entire absence of 
that profound selfishness which Adam Smith himself regarded as the main motive power in the individual whenever his material welfare was concerned.

Cosmopolitanism, which is to find expression in some vague form of international unity, has been the dream alike of the conquerors, from Crsar to Napoleon, and of the laissez-faire schoolmen. It has never yet been realised. The one class has approached no nearer to its attainment than the other. No conqueror will ever enforce it. No economic theory is likely to accomplish it. But in the course of political evolution it is conceivable that the gradual aggregation into larger groups of the various states of the world will, under the influence of federalism and negotiation, dictated in the interest of that security so essential to industrial and commercial development, bring us nearer to the hitherto ever apparently receding goal. If this state be ever reached, Cosmopolitical Economy will doubtless have its value. Until then Political Economy must be made to serve us, and in the interests of intellectual honesty let us endeavour to distinguish between the two.

After these preliminary observations it need hardly be said that in the writer's opinion the definition given in more or less general terms by the writers of the laissezfaire school of Political Economy is scarcely adequate. Questions of pure economics, regardless of all political considerations, should be frankly and dispassionately discussed and described as such; but where the term "political" is used, some national or political significance should also be implied.

Political Econoiny should deal with the relation of the State, the community, and the individual to production, distribution, and exchange, with a view to ascertaining 
the principles which promote stability, wealth, and productive power in the State, and the material welfare of all its citizens. Wealth without some guarantee of the permanence of productive power is a danger rather than an advantage to a State, and to promote the former, entirely regardless of the latter, is bad politics and worse economy.

To any inquiring student on the history and literature of Political Economy since the days of Adam Smith, the mass of matter by different authors, in different countries, more particularly in England and Germany, will be found to be embarrassingly great. To review it at any adequate length would be beyond the scope of a work of this nature, but it is only fair to say that the extremely controversial character of a great deal of this literature is sufficient evidence of the necessity for regarding many propositions, not infrequently described by their authors as " economic laws," with very considerable caution. In the realm of physics certain laws have been enunciated, such as the law of gravity, which have stood the test of time, but in the realms of metaphysics or sociology it is hard to find their parallel.

At the same time there is an undoubted bias, deeprooted in the human mind, in favour of formulæ, and such formulæ the various writers on Political Economy have readily supplied. But the doctrines expressed by such formulæ once embraced and assimilated, have a marked influence on the estimate, by those holding them, not only of the conclusions to be drawn from the results of any historical investigation, but also on the view taken of contemporary social or political phenomena. Should any of these doctrines be in their essence fallacious, the influence they exercise will be obviously misleading. 
Reference has already been made to the conception of the meaning and objects of Political Economy held by that most distinguished of the laissez-faire school of writers, John Stuart Mill. That both Mill and Ricardo have contributed much of permanent value and interest to the elucidation of many economic problems, no impartial reader will deny. Yet we find no less an authority than Jevons, in his preface to the second edition of his work on the Theory of Political Economy, announcing as his conclusion: "That the only hope of attaining a true system of economics is to fling aside, once and for ever, the mazy and preposterous assumptions of the Ricardo school". He subsequently speaks of the doctrines of this school as "Ricardo-Mill Economics," explaining how " that able but wrong-headed man, David Ricardo, shunted the car of economic science on a wrong line, a line, however, on which it was further urged towards confusion by his equally able and wrong-headed admirer, John Stuart Mill."

But whatever measure of this severe criticism may be merited by the two writers referred to, who in their over-zealous desire to formulate a new science have incurred such a sweeping condemnation from Jevons, they have at least been surpassed in this direction by a German writer, Von Thünen, who in his day was regarded as a great authority on the Political Economy of agriculture. He came to the conclusion, through a process of abstract mathematical reasoning, that the amount of "natural wages" should equal $\sqrt{a p}$, $a$ being taken as the necessary expenditure of the labourer for subsistence (a somewhat uncertain quantity) and $p$ as the product of his labour. Von Thünen attached so much importance to his formula that he left instructions to have it engraved on his tomb. But to the impartial 
reader this formula, like others of a similar kind expressed in less mathematical but none the less positive terms, savours more of a political or sociological opinion than of an economic law.

For the view, which this formula is intended in somewhat too exact terms to express, that the labourer should be encouraged to acquire some share in the profit of an industry, there is a good deal to be said. ${ }^{1}$ Certain large industrial corporations both in England and America are already, and very wisely, giving effect to such a view. The co-partnership system, in so far as it meets the natural desire of the workman for some relative participation in the wealth which, by his labour, he is partly instrumental in creating, is the best practical answer to the demands of Socialism which organised industry has yet made. But while the adoption of a principle of this sort may or may not, on ethical, social, and political, grounds be wise and expedient and even economically sound, it by no means follows that it is the expression of some nebulous academic abstraction described as an "economic law," much less that such a law can be expressed in the terms of a mathematical or any other formula. It is largely such a mistaking of opinion for axiom, on the part of Ricardo and Mill, which has evoked the scathing denunciation of Jevons. And it is this same mental attitude and method which has filled the shelves of reference libraries with tomes which are seldom read, or, if read, seldom remembered.

If Political Economy be regarded in any sense as a

1 The United States Steel Trust and certain large companies in England allow their workmen to obtain their shares in small quantities and on favourable terms.

Sir Christopher Furness has recently negotiated an arrangement whereby his workmen may acquire a participation in the profits of his business. 
science, and not as a branch of political literature, it must be frankly recognised that that science will vary from age to age in many vital and essential points. It will vary as the values set upon wealth, productive power, individual rights, the prerogatives of the State, and even such qualities as altruism and patriotism, vary. In fact, if it is to be described in scientific language at all, it can only be described as a "complex variable".

One of the soundest writers on Political Economy in the first half of the nineteenth century, and a very trenchant critic of some of the Ricardian doctrines, was Richard Jones-Professor at Haileybury-of whose work John Stuart Mill made considerable use. In regard to the procedure to be followed in studying Political Economy, Jones writes: "If we wish to make ourselves acquainted with the economy and arrangements by which the different nations of the earth produce and distribute their revenues, I really know but of one way to attain our object, and that is, to look and see. We must get comprehensive views of facts that we may arrive at principles that are truly comprehensive. If we take a different method, if we snatch at general principles and content ourselves with confined observations, two things will happen to us. First, what we call general principles will often be found to have no generality-we shall set out with declaring propositions to be universally true which, at every step of our further progress, we shall be obliged to confess are frequently false; and, secondly, we shall miss a great mass of useful knowledge which those who advance to principles by a comprehensive examination of facts necessarily meet with on their road."

He strongly objected to looking upon the world as being composed of theoretic "economic men," and insisted on the importance of studying the real world in 
its varying conditions, and different stages of industrial and general development. The view enunciated by this distinguished, though but little known writer, is one which was strongly held and acted upon by List. The advice is so eminently suited to the present stage of transition in economic thought and practice that it indicates the method which it is the writer's object to endeavour to follow. 


\section{CHAPTER II.}

\section{LAISSEZ FAIRE}

Restraints on manufacture in seventeenth and eighteenth centuries -Corn Laws-Limits of the laissez-faire principle-Infringements of the principle-Its application in exchange alone absolute-Labour protected-Free importation of products of foreign sweated labour-Application of policy in IndiaModern departures from principle even with imports-Predictions "of laissez-faire writers, Adam Smith, Mill, and Cobden-Natural Protection-Effect of free imports on agriculture-Contrast between the predictions of the laissez-faire schoolmen and of List.

IT is now necessary to examine some of the leading principles and doctrines propounded by the school of laissez-faire writers and politicians, which have largely dominated the economic thought of Britain for so many years, and also to consider the less widely known objections to many of these propositions which have been advanced by List and other writers.

We may begin by considering the doctrine of laissez faire itself. The origin of the expression in the writings of the French economist Gournay has already been referred to. The doctrine it expresses was not only adopted and expounded by Adam Smith in his Inquiry into the Nature and Causes of the Wcalth of Nations, but was also incorporated in the utilitarian philosophy of Bentham and his followers, and in the teachings of 
Ricardo and Mill and their political exponents of the Manchester school.

Coming as it did, when first introduced, as a protest of rationalism and individual liberty against restraints on the operations of manufacturers and trade which existed throughout Europe in the seventeenth and eighteenth centuries, it excited the eager attention of many writers, continental as well as English. The extent to which these restraints existed in such a country as France, even down to the Revolution, would be almost incredible if authentic records of them were not still in existence. One quotation from Roland, the Girondist Minister, cited by John Stuart Mill, will illustrate this point. Referring to certain minute tyrannical Government restrictions regulating the course of different industries, he writes: "I have frequently seen manufacturers visited by a band of satellites who put all in confusion in their establishments, spread terror in their families, cut the stuffs from the frames, tore off the warp from the looms, and carried them away as proofs of infringement; the manufacturers were summoned, tried and condemned; their goods confiscated; copies of their judgment of confiscation posted up in every public place; fortune, reputation, credit, all was lost and destroyed ".

When we further bear in mind that even in England as late as 1835 , under a continually fluctuating scale of charges, the duty on corn stood as high as $34 \mathrm{~s}$. 8d. a quarter, we shall realise the almost prohibitive measure of protection accorded to the staple article of food in this country. In the Free Trade agitation between the years 1839-47, principally directed in the first instance against the inordinately high corn duties, the arguments used were largely drawn from the teachings of Adam Smith.

The expression laissez faire was practically inter- 
preted in the domains of British industry and commerce by the term Free Trade-trade free, that is, from Government duties of any sort or kind. When the extreme measure of protection afforded to agriculture by the old Corn Laws is considered, it is easy to understand the cordial welcome accorded by the masses to an alternative policy. And although that policy may have been carried too far and its advantages over-stated and over-estimated, it at least swept away the excessively heavy duties imposed by the Corn Laws. ${ }^{1}$ That a policy which promised so much should be hailed as the outcome of a new gospel, the discovery of a new " economic law," is perhaps not unnatural.

But the high hopes and aspirations founded on this policy of laissez faire set too high a demand and value upon its potentialities. It accomplished muchit has contributed much to human thought and human action which will remain for ever a valuable inheritance. But that it cannot be regarded as the one final, determining and guiding law on the problems of international exchange and industry, history, since the policy was first introduced, has rendered abundantly apparent. Trades Unions, Factory Laws, Unemployment Bills-even the Poor Law, are all in the strictly economic sense interference with the laws of supply and demand, the freedom of contracts, the freedom of trade, and therefore infringements of the principle of laissez faire.

In his Principles of Political Economy John Stuart Mill has a chapter entitled "Of the grounds and limits of the Laissez Faire or Non-Interference Principle"." And in this chapter he indicates many directions in which a limit has to be set to the applications of such a principle.

${ }^{1}$ The Corn Laws are dealt with in chap. vii.

${ }^{2}$ Book v., chap. xl. 
Thus while eulogising the superior efficiency of private agency owing to the close and strong interest ensured in the work, the importance of cultivating habits of collective action in the people, and the desirability of making laissez faire the general rule, he points out that this rule is liable to large exceptions. He cites cases in which the consumer is an incompetent judge of the commodity. "The uncultivated cannot be judges of cultivation. Those who most need to be made wiser and better usually desire it least, and if they desired it they would be incapable of finding their own way to it by their own lights"...."Education, therefore, is one of those things which it is admirable in principle that a Government should provide for the people. The case is one to which the non-interference principle does not necessarily extend."

In the same way protection of children and young persons is provided for. Instances of this sort may be multiplied indefinitely.

Of the limitations placed on the application of the laissez-faire principle by Governments of all parties in England since Mill wrote we have innumerable instances. In fact the principle for all practical purposes has merely come to be regarded-outside the field of trade and industry - as an amiable expression of the natural desire of all free people to accord to individuals and groups of individuals alike as much liberty as may be consistent with, and expedient for, the general welfare of society.

Even in the field of trade and industry itself it is only in the portion dealing with exchange-the imports and exports of a country-that the principle is still held to have a certain sacro-sanct character, the least infringement of which would be attended by at least economic 
disadvantage. In dealing with the labour supply-the most important of the essential factors of industrymeasures have continually been carried in direct conflict with the principle of laissez faire and also in diametric opposition to the teachings of Cobden and the Manchester school. Labour is protected by a long series of Parliamentary Acts. Thus in the ten years from 1896 to 1905 alone there were put in force a number of Acts of this nature, of which the following were the most important:-

The Foreign Prison-made Goods Act. To prohibit the importation of foreign-made goods.

The Mines Act for the Prohibition of Child Labour underground.

The Factory and Workshops Act. A comprehensive measure bringing within one statute nearly a dozen previous Acts regulating and controlling the conditions of labour.

Further Acts on similar lines deal with labour in coal mines, the employment of children, shop hours, restrictions on the importation of aliens and unemployed workmen. The Unemployed Workmen Act constitutes an entirely new departure in English legislation, under which an organisation with a view to the provision of employment for workmen in proper cases was permanently instituted.

In every direction, then, it is evident measures have been taken to restrict labour conditions in accordance with requirements and considerations other than those of the laws of supply and demand. Labour has, and rightly has, by modern legislation certain privileges accorded it quite irrespective of purely economic value. It is protected in a measure from the unrestricted competition of labour at home, and through the Aliens Act to 
some extent from the unrestricted importation of aliens. But if we turn from labour to the principal products of labour, those manufactured goods which it is one of the chief objects of industry to produce, we find the doctrine of laissez faire still reigns almost supreme. It is true the importation of prison-made goods is prohibited, but the importation of goods the product of sweated labour in foreign countries goes on unchecked by legislation or import duty. In this manner British labour is directly encroached upon, in its own field, by the competition of cheap and unrestricted labour.

The principles of Free Trade, in the opinion of the Cobdenite school and British Governments for over half a century, demand that, no matter what their origin or conditions of production, manufactured goods, with the foregoing exceptions of prison-made goods, should be admitted free of any duty; or if, as in the case with wines and spirits, duties be imposed, the same articles, if manufactured at home, shall be subjected to a corresponding excise. This policy is not only adhered to in Great Britain but has been enforced in a remarkable way in India, where the native-made cotton and fabrics are subjected to an excise equivalent to the import duty on these articles, which for revenue purposes is levied on all imported goods in that country.

But in recent years there has been more than one instance in which a British Government has departed from the strict letter and spirit of this policy. Thus there is a duty on cocoa which is higher in the case of the manufactured powder than in that of the raw bean, and in 1907 the Liberal Prime Minister remarked in his Budget Speech: "I think there is a good deal of the flavour of Protection about the present scale of our 
cocoa duty. I should not defend it myself from the point of view of the free trader." In the same way a differentiation in the duties on stripped and unstripped tobacco, the Sugar Convention, the Patents Act, the Merchant Shipping Act, and other similar measures all indicate a relaxation in the strict application of the principle of laissez faire even in dealing with industry and trade.

Change in such a complex organisation as the fiscal system of a constitutionally governed country, dependent as it must be upon the gradual trend of opinion in the electorate, usually takes place at a rate which is by no means satisfactory to its more ardent advocates. The changes referred to may not amount to very much, and most of them have been, with not very successful ingenuity, defended even on Free Trade grounds. But they do appear to indicate a departure from the extreme rigidity of the laissez-faire school of statesmanship in the provinces of industry and trade, not unlike those already referred to in the province of labour. Nevertheless, in spite of these deviations from the straight and narrow way of economic infallibility, the doctrine and policy of Free Trade, or more accurately free manufactured imports, still has advocates of distinguished ability and sincerity, and still dominates, though in a slightly lesser degree, the fiscal policy of Great Britain.

In these circumstances it will be of interest to examine some of the arguments on which the founders of the Free Imports school based their views of Political Economy, and committed themselves to certain predictions the majority of which have remained unfulfilled. One thing on which both Adam Sinith and Cobden insisted, was that the free importation of foreign corn "could very little affect the interest of the farmers of 
Great Britain". Thus in his Wealth of Nations Adam Smith says :- ${ }^{1}$

"Even the free importation of foreign corn could very little affect the interest of the farmers of Great Britain. Corn is a much more bulky commodity than butcher meat. ... The small quantity of corn imported even in times of the greatest scarcity may satisfy our farmers that they can have nothing to fear from the freest importation."

The speeches and predictions of Cobden on this same subject have proved, as the following quotations will show, disastrously erroneous: "I have never been one who believed that the repeal of the Corn Laws would throw an acre of land out of cultivation. . . . Our object is not to diminish the demand for labour in the agricultural districts, but I verily believe, if the principles of Free Trade were fairly carried out, they would give just as much stimulus to the demand for labour in the agricultural as in the manufacturing districts" (Speech in Manchester, 19th October, 1843).

"So far from throwing land out of use or injuring the cultivation of poorer soils, Free Trade in corn is the very way to increase the production at home, and stimulate the cultivation of its poorer soils by compelling the application of more capital and labour to them. We do not contemplate deriving one-quarter less corn from the soil of this country; we do not anticipate having one pound less of butter or cheese, or one head less of cattle or sheep! We expect to have a great increase in production and consumption at home" (Speech in London, 8th February, 1844).

"As far as I can obtain information from the books of merchants, the cost of transit from Dantzig, during an ${ }^{1}$ Wealth of Nations, Book iv., chap. ii. 
average of ten years, may be put down at 10s. 6d. a quarter, including in this freight, landing, loading, insurance, and other items of every kind. This is the natural protection enjoyed by the farmers of this country" (Speech in House of Commons, 12th March, 1814).

"I speak my unfeigned conviction, when I say I believe there is no interest in this country that would receive so much benefit from the repeal of the Corn Laws as the farmer-tenant interest in this country. And, I believe, when the future historian comes to write the history of agriculture, he will have to state: 'In such a year there was a stringent Corn Law passed for the protection of agriculture. From that time agriculture slumbered in England, and it was not until by the aid of the Anti-Corn Law League, the Corn Law was utterly abolished, that agriculture sprang up to the full vigour of existence in England, to become what it now is, like her manufactures, unrivalled in the world' ", (Speech at Manchester, 24th October, 1844).

There are other fallacious views held and taught by Cobden, which will be referred to in a subsequent chapter, but an examination of the foregoing statements will show how great was his miscalculation in this most vital matter. With regard to the "natural protection" afforded the British grain-growers by freight, this charge, which was in Cobden's time undoubtedly a substantial protection to the home producer, in the case of all bulky produce, has been reduced to-day to a small fraction of what it was, and will become even smaller in the future. Railways and steamships have transformed the world. Thus freight from Chicago to Liverpool, which in 1866-70 stood at $15 \mathrm{~s}$. 11d. per quarter, had fallen by 1901-4 to only 3s. 11d. a quarter. Under these conditions it is perhaps not surprising, to find that the $2 *$ 
sanguine anticipations of the laissez-faire school with regard to the effect of free imports on agriculture have not been fulfilled.

Judged by any fair test that may be applied, there is no doubt that no industry has suffered more by the policy of unrestricted imports, or been more absolutely the viction of political miscalculation, than agriculture in Great Britain and Ireland. Thus statistics show (see table in footnote ${ }^{1}$ ): "(1) That the average area under corn crops in this country has declined since $1871-75$ by over $3,000,000$ acres, or by 28 per cent. (2) That the decline has been specially marked in the case of wheat, the average area under which has fallen by $2,060,000$ acres, or by 55 per cent. Thus the land which has passed out of wheat cultivation is considerably greater than the present wheat area of the United Kingdom. (3) That the decline has affected all the crops dealt with in the table, even oats showing a decrease."

If we turn to live stock, things are not quite so bad. Freight and sanitary precautions under various cattle diseases Acts, gladly enforced with the utmost vigour of

${ }^{1}$ Acreage under Crops in the Uniteu Kingdodi.

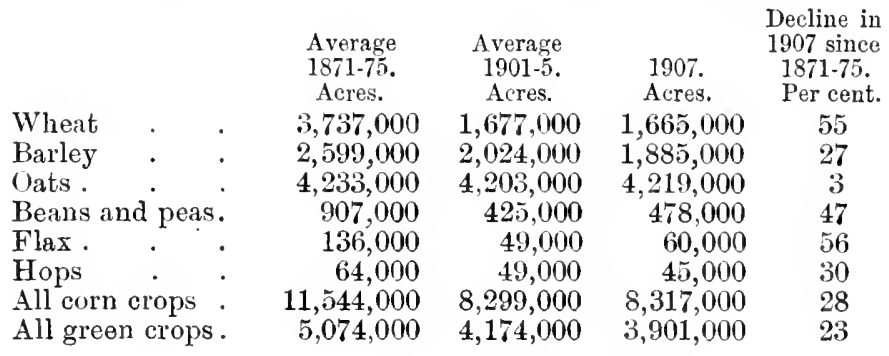

This and the following table have been compiled from Board of 'Trade Returus and other official documents for the Tariff' Commission. 
the law by the agricultural authorities under successive governments, have provided a certain measure of that "natural protection" which Cobden so confidently relied upon in the case of cereals. There has been a falling off ${ }^{1}$ during the last thirty years in the number of sheep reared in the country, but there is an increase in the number of pigs and cattle, although this increase has not kept pace with the increase in the population.

But the worst feature of all with regard to agriculture is the great falling off in the number of people employed on the land. Fifty years ago it is estimated that 2,000,000 people were engaged in agriculture in England and Wales, whereas to-day less than $1,000,000$ are so engaged.

It is therefore evident that however plausibly Free Trade advocates to-day may endeavour to explain the advantages of urban over rural occupations, the improvements in labour-saving machinery and other collateral developments, the original case as made by Adam Smith and Cobden for unrestricted imports, so far as agriculture and those interested in it are concerned, falls hopelessly to the ground. "Natural protection" has practically disappeared. Agriculture has gone back rather than forward. So far from farmers having had nothing to fear from unrestricted imports, the truth is that unrestricted imports have wrought havoc both in Great Britain and Ireland with farmers and agricultural landowners. No one who really has witnessed

${ }^{1}$ Number of Live Stock in United Kingidon.

Increase + or

1871-75. 1901-5. $\quad 1907 . \quad 1907$ as compared

Decrease - in

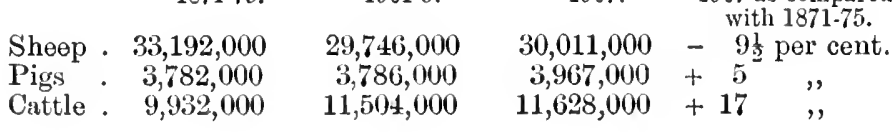


the country life of England during the past sixty years and has seen the depopulation of so many of our country villages, can doubt that in this direction at least a real national loss has been incurred, and one that, could Cobden witness it to-day, he would be the first to deplore. That the retention of a small tariff-something at least sufficient to partially compensate for the disappearance of the "natural protection"-would have been expedient, both on national and economic grounds, is highly probable.

But whether this change, so injurious to agriculture with its depopulation of our country villages, was or was not economically avoidable, the broad fact remains that it is the direct opposite of what Adam Sinith and Cobden foretold. And it is perhaps as well that those who still believe, follow and advocate implicitly, and in their entirety, the economic teaching of these Free Trade leaders, should realise that one of the argumentsthat of "natural protection"-though potent sixty years ago is eliminated to-day.

Another belief, held with all the fervour with which a man who thinks himself the apostle of a new gospel to mankind is capable, was Cobden's conviction that if his country once introduced Free Trade her example would speedily be followed by all the rest of the world.

Thus, speaking at Manchester on 15th January, 1846, he said :-

"I believe that if you abolish the Corn Law honestly and adopt Free Trade in its simplicity, there will not be a tariff in Europe that will not be changed in less than five years to follow your example".

And even John Stuart Mill, a less impassioned orator, but a more scientific student of economics, was evidently, 
when writing his Principles of Political Economy, of the same opinion.

Thus he writes: ${ }^{1}$ -

"In countries in which the system of Protection is declining, but not yet wholly given up, such as the United States, a doctrine has come into notice which is a sort of compromise between Free Trade and restriction, namely, that Protection for protection's sake is improper, but that there is nothing objectionable in having as much Protection as may incidentally result from a tariff framed solely for revenue".

That was John Stuart Mill's conception of how things were trending in the United States in 1848. Yet since then, although there have been from time to time readjustments of the tariff in the direction of freer trade, the manufacturing industries of the States have grown up under a protective tariff, and in 1899, after a period of prosperity following on the famous McKinley tariffone of the highest the world has seen-Mr. McKinley said at Chicago:-

"I have come ... to congratulate you and your fellow-workmen everywhere upon the improved condition of the country and upon our general prosperity".

Earlier in the same campaign he said:-

"We want no Free Trade in the United States. . . . The capitalist can wait on his dividends, but the workingman cannot wait on his dinner."

If, therefore, the imposition of a tariff for protective as well as revenue purposes be, as Mill and his followers held, improper, it must be conceded that not only the United States but all other civilised countries, including our own self-governing colonies, have, since the days of Cobden and Mill, launched upon careers of the most

${ }^{1}$ J. S. Mill, Principles of Political Economy, vol. ii., p. 487. 
flagrant economic "impropriety". So far indeed from following England's example in adopting free imports, they have gone in precisely the opposite direction and have imposed tariffs not merely for revenue purposes but also with arowedly protective intention and effect.

The failure of the world to follow, as was anticipated, the Cobdenite Free Trade lead, must, therefore, be accounted as one more of those miscalculations for which the laissez-faire school were responsible. And, as a perusal in later pages of List's forecast will show, these miscalculations offer but a sorry contrast to the predictions made by List as to the effects of the policy he advocated.

The idea that natural conditions of production were to be allowed free play all the world over was a fascinating idea with a fine cosmopolitan air which thoroughly commended itself to Mill the philosopher and Cobden the cosmopolitan visionary of his age. Moreover, it had this further advantage, which no doubt both Mill and Cobden viewed with adequate complacency, namely, that, if carried out, we should remain and become still further the workshop of the world, receiving the comparatively immense revenues of industry, while the United States, our own colonies, and many other countries would remain content to recognise our unique natural advantages, and to supply us with raw materials and food-stuffs in return for our manufactured goods. In other words, manufacturing industry with all its wealth and appendages were to be ours; pastoral simplicity to be theirs. The scheme from our point of view was admirable. But other countries saw it in a different light. In fact, List, Füchs, and other German writers have not hesitated to assert that there was a certain unctuousness in our economic rectitude.

List had indeed, as already pointed out, gone so far 
as to challenge the very meaning of the word Wealth as conceived and defined by the British economists. $\mathrm{He}$ contended, and with a considerable degree of justice, that Wealth is not merely the amount of exchange values in a State at any given time, but that it also includes productive power. Wealth without the assured potentiality of continuing to produce it within the State is, from a national point of view, but a precarious asset.

Nevertheless if the world at large rejected the scheme of universal Free Trade, Great Britain at least has put it, so far as she was able, in force. We have had free manufactured imports. We have had the chief articles of food as cheaply as the world could supply them. But we have seen the United States and Germany scouting the dreamer's cosmopolitan paradise and deliberately building up industries under protective tariffs, not only rival but surpass us in several directions. ${ }^{2}$ The subjoined

${ }^{1}$ Comparative Steel Production.

Amnual average in

$187 \overbrace{6-80 .}-1907$.

Million tons. Million tons.

United Kingdom, $1 \cdot 0$

France ? $: 3$

Germany · $\quad \cdot 5 \frac{5}{5}$

$\begin{array}{llll}\text { United States } & \cdot & 8 & 23\end{array}$

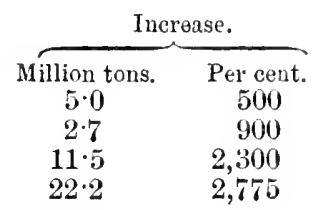

Comparative Consumption of Raw Cotton.

Ammual arerage in

\begin{tabular}{|c|c|c|c|c|}
\hline \multirow[b]{3}{*}{ United Kingdom ${ }^{1}$} & & \multirow{2}{*}{\multicolumn{2}{|c|}{ Increase. }} \\
\hline & $1 \longdiv { 8 8 3 - 8 7 . }$ & $1903-7$. & & \\
\hline & Million lb. & $\begin{array}{l}\text { Million ib. } \\
1,786\end{array}$ & $\begin{array}{l}\text { Million } 1 \mathrm{~b} . \\
342\end{array}$ & $\begin{array}{l}\text { Per cent } \\
24\end{array}$ \\
\hline Germany ${ }^{2}$ & 418 & 1.000 & 582 & 139 \\
\hline \multirow{2}{*}{$\begin{array}{l}\text { United States (yea } \\
\text { ending 30th Jun }\end{array}$} & & & & \\
\hline & e) ${ }^{3} 999$ & 2,312 & 1,313 & 131 \\
\hline
\end{tabular}

${ }^{1}$ Net imports, i.e., total imports less re-exports. returns.

${ }^{2}$ Imports for home consumption according to German official

${ }^{3}$ Total estimated consumption of cotton of domestic and foreign origin according to United States official returns. 
tables will show the relative progress of the steel and raw cotton industries in the three countries.

Thus if free production and exchange under natural conditions the world over have not come about, certain unforeseen conditions have. We are by no means today the workshop of the world. There are many other workshops. Moreover, our dependence upon other countries for food-stuffs, particularly for wheat, exists to an extent unknown in any other country.

In fact it may fairly be stated that the policy of laissez faire or Free Trade, carried out in the midst of a protectionist world, has really produced a more unnatural and unsymmetrical state of things in England than any scientific tariff has produced anywhere else.

This condition at home, with hostile tariffs everywhere abroad, is very far removed from being a fulfilment of the predictions of Cobden or the anticipation of Mill. Time has thus disposed of the value set on "natural protection," and also of the sanguine Free Trade forecast as to the economic salvation of mankind at large on cosmopolitan Free Trade lines.

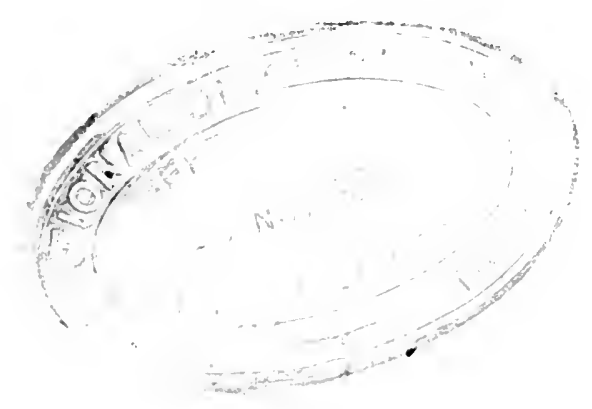




\section{CHAPTER III.}

SOME ECONOMIC FALLACIES.

Do imports balance exports?-The views of Mill, Farrer, the Fiscal Blue Book, and Lord Avebury-Sources of importing power other than exports- No necessary or constant relation between imports and exports of commodities-Character and extent of each must be studied separately-Effect of the suggestio falsi is to stifle discussion and paralyse action-The degradation of industry-Instances of erroneous conclusions arrived at by Lord Farrer and Lord Avebury as to the effect of imports on our exports-Goods not necessarily paid for by goods-Foreign investments-Their magnitude and influence on imports-Displacement of British labour-Professor Marshall and change of employment-Capital and labour-The incidence of the burden of import duties under different conditions-Mr. Deakin on import duties-Recapitulation-The alternatives before us.

There is a doctrine propounded by John Stuart Mill, and reiterated by such authorities as Lord Farrer and Lord Avebury, which carries great weight and which calls for careful analysis and impartial examination.

This doctrine is that imports always balance themselves by exports, and vice vers $\hat{t}$; and it is of such a subtle and complex character that it has given rise to a greater amount of misapprehension than probably any other tenet in the whole gamut of the laissez-faire writers. Moreover, it is generally accepted by Free Trade writers, politicians, and speakers as an established "economic 
law," and is continually appealed to as an argument in itself sufficient to meet any question which may be raised as to the quantity and quality of imports and their possible influence on British industries.

At the outset it is interesting to note that this doctrine in all its modern extravagance was certainly never propounded by Adam Smith. Thus he writes:-1

"A nation may import to a greater value than it exports for half a century, perhaps, together."

This is a plain statement of fact which it requires no great effort of the intelligence to understand, when the profits of foreign, investments, shipping, and all other sources of importing power besides that of manufacturing industry, are borne in mind. The squaring of the circle was left to later and less lucid writers, and John Stuart Mill ${ }^{2}$ appropriately introduces what he has to say on the subject as follows:-

"I must give notice that we are now in the region of the most complicated questions which Political Economy affords; that the subject is one which cannot possibly be made elementary; and that a more continuous effort of attention than has yet been required, will be necessary to follow the series of deductions. The thread, however, which we are about to take in hand, is in itself very simple and manageable; the only diffculty is in following it through the windings and entanglements of complex international transactions."

The writer then proceeds to consider a number of hypothetic cases which lead him, as I venture to think, quite erroneously to the following conclusion:- ${ }^{3}$

"The law which we have now illustrated may be

1 Wealth of Nations, p. 389.

'J. S. Mill, Principles of Political Economy, vol. ii., p. 122.

${ }^{3}$ Ibid., p. 133. 
appropriately named, the Equation of International Demand. It may be concisely stated as follows. The produce of a country exchanges for the produce of other countries, at such values as are required in order that the whole of her exports may exactly pay for the whole of her imports."

A proposition in such precise terms as this, described as a law, and coming from such an authority as Mill, has carried great weight, and it will be interesting to trace its history in later literature on economics. In 1887 Lord Farrer, in discussing the balance of exports and imports, realised that he would have to give to the term exports a much wider significance than was given it by Mill in his Principles of Political Economy. Thus referring to imports he says: "They are not given to us. How then are they paid for? ... they can only be paid and accounted for in two ways. First, by the goods which we now export to pay for them; or, secondly, as a means of receiving and settling the interest due to us on foreign debts. But how were these foreign debts incurred? By the export of British goods or services in past years and in no other way.'

To come to still more recent times it is interesting to note the language used in the "Fiscal Blue Book" 1 prepared in the Board of Trade in 1903. In a "Memorandum on the Excess of Imports into the United Kingdom," the author says :-

"Of the whole of the commercial and financial transactions between any country and the outside world, which over a period of years, though not necessarily within the limits of any single year, must balance one another, only a portion are embodied in the commodities

${ }^{1} \mathrm{Cd} .1,761,1.99$. 
which pass outward and inward as exports and imports. There is thus no necessary equality between the values of imports and exports of commodities. As a matter of fact, for many years imports into the United Kingdom have always exceeded exports. An inquiry into the causes of this excess of imports is, therefore, an inquiry into the nature and value of the unrecorded transactions and services rendered and received which, one year with another, will balance the account."

We seem to be travelling somewhat away from "the law," as defined by Mill, when we arrive at the statement that "there is no necessary equality between the values of imports and exports of commodities".

The excess "for many years" of imports into the United Kingdom over exports, calls for something more than the export of mere visible commodities if the balance is to be maintained. Against the vast excess of imports over exports, amounting in 1902 to

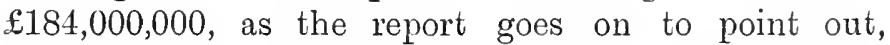
there must be added in addition to the visible exports such invisible contributions to the export side of the account as the earnings of the carrying trade both home and foreign, and the interest on foreign investments. How these important items of revenue can by the most liberal and elastic application of the term be accurately described as exports it is a little difficult to understand, except on the assumption that there is a prejudiced desire to preserve the formula that, " exports balance imports" at all costs! Foreign investments are sources of importing power, but to speak of them as exports is merely to create confusion of thought.

But there are other sources of payment for imports which surely even the most extreme Cobdenite must hesitate to describe as "exports". Take, for instance, 
the case of a wealthy American or other foreigner who, coming to reside in this country, purchases motor cars, Parisian dresses, jewellery and other commodities which enter this country as imports and are paid for either by foreign cash or drafts on foreign banks. In what way are such imports to Great Britain paid for by British exports?

Can it be alleged that the money paid in this case, say from America to France, by cash, notes or bills of exchange, gives France an additional buying power which must necessarily be exercised in England, or to use the favourite method of Cobdenite economists, be exercised in some third country which in its turn will buy from England? If so, the answer is that such a course of events is dependent on conditions entirely independent of the original purchase, conditions of supply and demand, import duties, and a dozen other factors.

The fact is-quite apart from such exceptional cases as the foregoing- "the law" that exports pay for imports can no longer be maintained, except by extending to the term exports a meaning which it cannot fairly be held to convey. This is practically admitted by Lord Farrer and the authors of the "Fiscal Blue Book". And when the latter authorities stated as their conclusion that there is " no necessary equality between the values of imports and exports of commodities," they might equally well have stated on the strength of the evidence they themselves adduce in their report, that there is no necessary or constant relation between the imports and exports of commodities.

This being so the constant appeal to the exploded "law" that "exports pay for imports," for the purpose of stifling all discussion on the character and significance of such imports, is fallacious and misleading in the last 
degree. It is perfectly obvious from the foregoing considerations that as no necessary or constant relationship exists between imports and exports of commodities, it is essential that the character and extent of each must for practical commercial purposes be studied separately. It is also obvious that imports of commodities may under certain conditions increase, not only without any necessary corresponding increase in the export of commodities but even coincidently with an actual decrease in such exports.

When this is borne in mind it will be seen how entirely erroneous is the suggestion that an increased import of manufactured goods must necessarily be paid for by an increased export of manufactured goods. It is a "suggestio falsi". Yet this suggestion is continually made, as will be gathered in the following pages. Free Trade writers appear to believe that it matters not what the excess of imports over visible exports may be, nor what is of even more importance, what the character of either may be. Let us, they urge, import as much as we please, free of any duty, the most highly manufactured goods, raw produce, food supplies, anything, everything without let or hindrance, saving only such articles as tea, coffee, sugar and tobacco-articles which we must have and cannot produce, and on which every penny of tax goes into the public revenue.

From the consumer's point of view there is no gainsaying that at the first blush this is an attractive picture. So long as he derives an assured and fixed income from somewhere he has little to complain of. To a consumer so situated, the character and extent of such exchange as exists between the whole of the imports and the whole of the exports may appear unimportant. But let that consumer be dependent, as the vast majority 
of consumers eventually must be dependent, on the prosperity of some industry or industries in this country, let him once realise that the national wealth and welfare are bound to influence his life history, and how completely is the problem changed.

The character and the extent of the exchange of the exports and imports of commodities then becomes to him of the most vital importance. If, for instance, as in the woollen trade, he finds that foreign manufactured articles are underselling his product in the home market, and that foreign tariffs prevent his selling to any certain extent his products abroad, he may well complain of an exchange in which he individually is hit both ways. It is true an ardent free trader would perhaps endeavour to explain to him that the increased export of combed and scoured wool and of coal was an adequate compensation for the trade lost, but to him the difference might mean unemployment and misery. Moreover, to the country the change would be equally disastrous, because the latter commodities being semi-raw and raw material, they require for their production considerably less industry than the former. Such changes constitute a degradation of the industry so affected. And as Napoleon long ago foresaw, after the world had once been mapped out and occupied, the prize for which nations would compete would be industry, and especially those forms of industry largely employing labour.

Again, to take an extreme case, it is obvious that if every furnace in Great Britain were extinguished, and every factory closed, there would still be exports and imports, and that so long as interest on foreign investment is accounted an export they would, to some extent, balance, but half the population of England would be starving. To the Free Trade optimist (of the Pangloss 
type) this may appear an untenable proposition. If it is so let him consider what the facts of such a situation would be. The man with foreign investments, representing as he does a large and wealthy class in England to-day, would still have his dividends and he would still require many imported articles. For these articles a large portion of his dividends would be exchanged.

In addition to Mill and Lord Farrer, ${ }^{1}$ Lord A vebury ${ }^{2}$ has held and enunciated in uncompromising terms the view that imports from abroad are paid for by manufactured exports from this country. Thus Lord Avebury says, "The products of one country are exchanged for those of another. Goods are paid for in goods." Such a statement as this, which takes no account of other sources of importing power already referred to, is most misleading. The followers of these writers, accepting statements of this character without qualification, continually assert that as imports must be paid for by exports, they must in some mysterious way create a demand for a corresponding export of commodities. That "goods paid for goods" sixty years ago is largely true, but it is not true to anything like the same extent to-day.

In the era before Free Trade the English formula was to pay for the imports of raw materials by the export of manufactured goods. Cobden, the apostle of Free Trade, based himself on the proposition that England should be the workshop of the world, and that other nations should exchange their raw material for England's manufactured goods. How far are free traders driven from this position-common to both the pre-Free Trade protectionists and to the early Free Trade protagonists - when they are content to advance fallacious arguments

${ }^{1}$ Farrer, Free Trade v. Fair Trade, p. 120.

${ }^{2}$ Rt. Hon. Lord Avebury, Free Trade Address in Dundee, p. 4. 
about exports balancing imports, and are profoundly careless whether they import manufactured goods or raw materials, or whether they pay for what they import by means of foreign investments, raw material, or partly manufactured goods? Is it not time that the British producer took steps to secure his only means of livelihood, and to conserve that "productive power" which is more important than mere wealth?

As the interest on foreign investments is such a growing factor in importing power, it will be interesting at this point to consider the subject. The amount of British capital invested abroad is enormous. "The Fifteenth Report (dated August, 1907) of the Commissioners of H.M. Inland Revenue" for the year ending 31st March, 1907, gives figures of "identified" income from foreign investments assessed for income tax, the increase of which in the preceding fiscal year it describes as "remarkable". Sir Joseph Lawrence estimates from the official returns that in twenty years over $£ 500,000,000$ have been invested abroad in securities, whose interest is paid and the income tax collected in bulk. The "identified " income received in this country is rapidly increasing, and in the year 1905-6 amounted to $£ 73,899,265$. Imports are largely paid for by the interest of these foreign investments, and these figures are in themselves sufficient to show how impossible it is to argue from the amount of our imports with regard to the success of our manufacturing industries. Yet in the address delivered by Lord Avebury in 1908, ${ }^{1}$ already referred to, in dealing with a suggestion for a tariff on manufactured goods, he says, taking silk, which is chiefly imported for the use of the wealthier classes, as an instance: "How do we pay for the silk? By an export

${ }^{1}$ Avebury, Free Trade Address in Dundee, 1908. 
of equivalent value, say of cotton goods or iron." The silk will be paid for, no doubt-but to suggest that it will necessarily be paid for by goods of cotton or iron is really to beg the whole question. It may be so paid for, but on the other hand, it may equally well be paid for by the interest on foreign investments. The figures already quoted will suffice to show the amount of these foreign investments. And in the face of them it is no longer possible to argue that say $£ 1,000$ worth of imports must necessarily be paid for by $£ 1,000$ of goods manufactured in England.

It is true of course that much of this wealth invested abroad is the product of profit made in British industries in the past. But even granting this, it is but a slender consolation to the unemployed workmen of today to be assured that the imports of perhaps the very article he used to manufacture-but manufactures no longer-are being paid for by the profits of home industry employing thousands of his predecessors many years ago. Moreover, if this capital invested abroad be largely the accumulation of profits made in the past, it is not by any means entirely so. It is often largely increased by the success of the foreign enterprise in which the capital is invested, not infrequently a protected ind ustry, the products of which compete with British industries, such as the United States Steel Trust. It may at any time be increased, and to-day is continually being increased, by capital withdrawn from unprofitable home industries. And herein lies one of the most important of all the modern conditions introduced into the problem.

Lord Farrer, ${ }^{1}$ in his interesting book, writing with some impatience of those who deplore the decline of any particular British industry, says :-

${ }^{1}$ Farrer, Free Trade v. Fair Trade, pp. 119-120. 
"For instance, I find in one of the Fair Trade tracts a long and graphic description of the making of a plough in England, and of all the English people employed in preparing the materials and putting them together. The whole culminates in the sale of the English-made plough to a farmer for £12, whilst a similar article might be imported from abroad for $£ 11$ 10s. All this is for the sake of the following precious piece of political wisdom :-

"I must deal with the question in its practical bearing, and tell you that the dogma, "Buy in the cheapest market," is a great delusion, for, in the case of the plough which produced $£ 12$ to the whole nation, if it could be bought from the foreigner for $£ 11$ 10s. the whole nation would certainly gain 10s., but would lose the $\$ 12$ by the collapse of that special industry, the nation, from the Government down to the candlestick-maker, being poorer by $\mathrm{f11} 10$ s. in distributive veealth."

"Astounding conclusion! How do the fair traders think the imported foreign plough is to be paid for? With nothing? If so, then the nation will be richer not by 10 s., but by $£ 12$. If with something, then with what? Why, of course, with something which English workmen can make better and cheaper than they can make ploughs, and which will have to be sent abroad, and there sold to pay for the plough."

How misleading is the last sentence in this paragraph has already been demonstrated.

But Lord Farrer's statement has this further point of interest, it is an indirect way of stating another fundamental doctrine of the Free Trade school which is continually reiterated in one form or another by Cobdenite speakers and writers. Perhaps the latest and most remarkable enunciation of this doctrine comes from Pro- 
fessor Marshall in his official Memorandum to the Treasury, entitled Fiscal Policy of International Trade, published in 1908, in which he says:-

"A chief corner-stone of our present policy is the great truth that the importation of goods which can be produced at home does not in general displace labour, but only changes the direction of employment."

This policy, of which the "great truth" is, we fear, a particularly fallacions portion, is based upon the assumption that capital and labour driven out of one British industry by foreign competition will automatically, as it were, flow into another more profitable British industry. If this were true, Free Trade would, indeed, have a potent argument in its favour. But unfortunately it is not. Capital is daily becoming more and more an international commodity. And capital once dislodged is chiefly to-day invested elsewhere in accordance with the amount of security and interest offered. There is no law of nature, of the land, of Political Economy, or of common sense compelling an unfortunate investor to reinvest what may be left of his capital in the very country in which he has recently been losing it. With the aid of telephones, cables, and stock exchanges in every city in Europe and America, capital is wafted about the world to-day almost as by the waving of a magician's wand. There never was a time when an investor could keep so closely in touch with his foreign investments, nor a time in which the securities of huge corporations, such as the railways and great industrial corporations of America, could be so freely dealt in as at the present time.

Capital is mobile. Labour is very much less so; but is this comparative immobility of labour any advantage to it? Is it any guarantee that it will, "when dis. 
placed," in accordance with Professor Marshall's " great truth," merely have the direction of its employment changed? Professor Marshall, with that fond adhesion to a faith which has characterised so many of his laissez-faire predecessors, clings to the belief that the tenets of his creed are "economic truths as certain as those of geometry." If the "great truth" quoted be accounted one of them, the fabric must be fragile indeed. In the case of any British industry from which both capital and labour have been dislocated by foreign competition and from which the capital has been reinvested abroad, what new power is called into being which will necessarily create a demand for that displaced labour in some other industry in England?

It is true, it may be urged, that the foreign investment stimulates trade and demand in the country of investment, and that some of that demand may be for English goods, and that so English labour may eventually be employed in consequence of that investment. But consider the long train of assumption or rather conjectures bere involved. Such a train of events may occur, but there is no assurance that they will. If the country of investment like the United States has a stiff tariff, the chances are that the demand from England for manufactured goods created by a British investment in that country will, owing to the tariff, be relatively a bagatelle. The investor, if bis investment be sound, will get his dividends, and those dividends may go to pay for say silks and motor cars imported into England; but what chamnel of employment is hereby opened up for the British workman " displaced" from a decayed industry?

The fact is, in spite of the increased facilities of transportation, labour, especially in old countries, tends to become largely rooted to the spot. A man with a wife 
and family and a home dependent on his weekly wage, deprived of his occupation and of funds, cannot so easily plant himself elsewhere. The very fact that wages in different localities of the same country vary considerably even in the same occupation is evidence of this. And if there be this want of freedom in movement of labour from place to place, there is even less freedom in moving from one avocation to another. A skilled workman in one industry thrown out of employment cannot at his pleasure forthwith become a skilled workman in another. At the best, if he is fortunate enough to get work, he will almost certainly have to sink to the level of unskilled labour, from which, if he ever emerges, it can only be after a period of painful uncertainty.

Unemployment bureaux and workmen's associations may do much, and should do more, to lessen these evils; but minimise them how we may, the fact remains that no industry can be curtailed much less destroyed in any country without inflicting grave injuries both upon capital and labour, but most emphatically upon labour.

With regard to import duties and the incidence of their burden under different conditions, it is usually contended by Free Trade writers and speakers that the cost of any imported article which is also manufactured in the country will, if a duty be placed upon it, be increased to the consumer by the full amount of the duty imposed.

A careful analysis of what actually occurs will show that the result is dependent on many other conditions. In the case of articles which are not manufactured or produced within the country, such as tea, coffee, sugar and tobacco, it is obvious that any duty placed upon them must result in an increase in the cost of these 
commodities to the consumer equal to the amount of the duty imposed. Further, the whole of the amount paid in this additional cost goes to the revenue. But where an alternative source of supply of any commodity exists within the country imposing the duty, or from any other country under a preferential tariff, a new and variable factor is introduced into the problem. If a heavy duty be imposed, the article subjected to the duty may cease to be imported altogether. In this case the cost of the article of home manufacture would probably for a time be raised to the consumer, though competition might again reduce it. In such a case there would be nothing for the revenue, because there would be no imports to tax. But if, on the other hand, moderate duties were imposed, and the articles were not excluded altogether but continued to be imported in diminished quantities, the price to the consumer would probably either not be increased at all, or only to an extent less than the amount of the duty. The reasons for this are not difficult to understand. Thus a freshly imposed moderate duty would exclude not the whole, but only a portion of an import, where producers abroad would rather sell such export at a smaller profit than forfeit the sale of it altogether. Certain conditions in the exporting country, such as proximity to the port of export, or circumstances specially favouring production, would, and as a matter of fact notoriously do, insure, though usually in a lesser degree, the continued export of a commodity, on which a moderate foreign duty is placed, to any country with which a trade has already existed, imposing such duty. Where this effect is produced a portion of such duty is borne by the foreign exporter. At the Colonial Conference of $1907 \mathrm{Mr}$. Deakin-the Australian Premier-dealt 
with this point in clear specific terms. Thus he said :-

"TVe have illustration within our own country in which we have imposed duties of a definitely protectionist character, which have not had the effect of raising prices in our community. Of course, no statement whatever can be made as to the effect of 'duties' which would apply to all of them, or even to many of them. They may be of any height, or of any character, apply to any part or totality of a product. There are duties some of which would be no tax at all, some of which would impose a partial tax, and some which might be wholly taxes. If I do not err, all the duties in this country (Great Britain), with possibly an exception for cocoa and chocolate, which have a slight protectionist flavour - with that single exception - so far as I know-the duties in this country (Great Britain) are imposed as taxes, so to speak, that is with the sole purpose of raising revenue."

Where instances-such as those to which Mr. Deakin refers-occur in which duties do not raise prices at all, it may fairly be held that the whole of such duties must be borne by the foreign exporter, and that no portion of them falls on the home consumer. Also where prices are raised to an amount equal to only a portion of the duty, the burden of that duty falls partly upon the foreign exporter and partly upon the consumer.

Ve are thus obliged to admit that the effect of import duties on the consumer, the foreign exporter and the revenue may, and undoubtedly'does, vary under different conditions, and that no case can be made the subject of a hard and fast rule, either in favour of the home consumer or the foreign exporter, but must be considered on its individual merits. 
Where, however, a duty has the effect of diminishing the import of any particular commodity, it is obviously advantageous at least to the home manufacturers and workmen who produce that commodity. The extent, if any, to which the consumer is called upon to contribute his quota to this advantage is, as the foregoing considerations indicate, subject to considerable variation. But even where the price of the commodity subjected to duty is appreciably raised it does not necessarily follow that the burden on the consumer is any greater than the amount received by the revenue, which it must be borne in mind the consumer pays in full in the case of the purely revenue-producing, non-protective duty on such articles as tobacco. This point has been dealt with both by Professor Seligman in his Incidence of Taxation and by Professor Sidgwick.

A hypothetic case somewhat similar to one discussed by Professor Sidgwick may serve to make this point more clear, and also to illustrate the force of the preceding propositions. Suppose that a 10 per cent. duty be placed upon imported gloves and that as a result half the gloves purchased by the consumer came to be supplied at home and half from abroad, and that the price is raised by 5 per cent. Of the 10 per cent. duty paid on the gloves imported, or half the quantity purchased, 5 per cent., or half the duty, would be borne by the foreign exporter, who would now get $£ 95$ for what formerly brought him $£ 100$, and 5 per cent. would be paid on the price of the gloves by the British consumer, who would pay $£ 105$ for what formerly cost him $£ 100$.

On the remaining half of the gloves purchased, the consumer would pay $£ 105$ for what formerly cost him $£ 100$, or another 5 per cent. on the gloves manufactured at home. The consumer would thus pay on his entire 
supply of gloves an additional 5 per cent., which would be equal to 10 per cent. on half the supply, or the quantity of gloves imported. But as the revenue would receive 10 per cent. on the imported gloves, it will be seen that in this case the British consumer would pay no more in increased cost of gloves than the revenue would receive in duties. At the same time the British manufacturer would have an advantage of 10 per cent. in price over his foreign rival. Thus in an instance of this sort the country imposing the duty gets the full value of the duty for revenue purposes, and at the same time confers a measure of protection upon her own manufacturers and workmen.

Where the import is less the revenue derived is smaller and the advantage to the manufacturer greater, and on the other hand, where the import is larger the revenue derives mole, and the manufacturer less, advantage. The foregoing analysis of different cases will show how fallacious is the popular argument of free import advocates when they declare that a duty cannot both furnish revenue and protect. In the vast majority of cases it does both, though in different relative degrees, in different instances.

From the considerations already adduced in this and the foregoing chapters it will thus be seen that, in dealing with the laissez-faire policy to-day, we are in a different position from that which confronted the founders of the Manchester school sixty years ago. The "natural protection" to agriculture on which Cobden relied has practically disappeared. Foreign countries, instead of following our example, as John Stuart Mill and Cobden anticipated would be the case, 
preferred to try what could be gained by adopting in fuller rigour the system of Protection under which England originally became the workshop of the world. Further, the "doctrine" that capital and labour displaced from one British industry by foreign competition will promptly flow into some other equally or more lucrative British industry has less truth in it to-day than at any previous time. In only too many instances the capital goes abroad and the labour remains at homeunemployed. But whether or no these and many other latter-day conditions do or do not indicate the political economic desirability of modifying the present Free Trade system, still in vogue in England, in favour of a policy with less traditional fiscal restrictions and a wider basis of taxation, must depend on the ideal which we set before ourselves.

If before and above all other considerations we insist on buying everything in the cheapest market, no matter what our selling facilities may be, how many workmen are thrown out of employment, how many emigrate, how many industries decline, how much labour is diverted from a higher to a lower grade of manufacturing industry, or from an industrial manufacturing function to one of transport or personal service, or finally how many are deprived of the means of buying anything at all, then we shall still remain free importers.

But if, on the other hand, we desire to retain in as many industries as possible a strong productive power, employing a large amount of capital and labour at home, and if we desire to preserve some degree of symmetry in our national development, we shall realise the impossibility of continuing for ever in the midst of 
a protectionist world a rigid policy of free manufactured imports, under which our manufacturers and workmen are subjected in bad times and good-but more especially in bad times-to a competition of an unfair and a one-sided character. 


\section{CHAPTER IV.}

\section{AMERICA AND PROTECTION.}

Alexander Hamilton-The problems before lim-American influence upon List-The fiscal system an instrument of Federation in the United States and Germany-The Constitution of the United States-Hamilton's "Report on Manufactures"-'The attraction of foreign capital and labour-Symmetrical national development-Lord Avebury condemus Protection in America - His alternative considered-Hamilton's condition for acceptance of Free Trade-Universal Free Trade-Mr. A. Mosely's Memorandum on American Tarifts-Remarkable progress in steel and cotton industries-Could better results have been obtained under policy of laisse faire?

HAVING briefly dealt in the foregoing chapters with some of the purely literary and theoretic aspects of Economics, it will now be of interest to turn our attention to the actual practice of different great nations in adapting the principles of economics to their varying requirements. And as the fiscal policies of the United States and Germany both offer modern illustrations of fiscal systems in most respects opposed to that now practised in the United Kingdom, a consideration of these systems and their results in the two countries will the better enable the reader to estimate the nature of the present British system-which will be more fully dealt with in the later chapters on Great Britain and her colonies.

The great part which Alexander Hamilton, firstly as Washington's secretar'y and later as an American statesman, played in moulding the destinies of his country 
has recently been set before English readers in two works of exceptional power and interest. In the first, The Conqueror, by Gertrude Atherton, we have the man full of courage, lofty patriotism, intellectual power amounting to genius, indefatigable energy, and strong tides of human passion, which together make up a character of profound dramatic force and abiding interest in the history of mankind. In the second, Mr. Oliver's book, Alexander Hamilton-An Essay on American Union, we find a critical analysis admirably and concisely executed of Hamilton's life-work. For the purposes of such a treatise there fortunately exists adequate literary material, which, though but little known to the ordinary English reader, has been exhaustively studied by Mr. Oliver.

What will appeal to every serious student of the history, economics, and politics of the British Empire, in Hamilton's career, was the set of national and political problems with which he found himself confronted on entering public life. His perspicacity, directness, and resolution in addressing himself to these problems; the philosophic detachment of mind which he brought to bear in considering them; the methods and policy he advocated, and the amount of success or non-success which eventually resulted from their adoption; are all of them matters not merely of great historic interest in themselves, but of the greatest instructive value to all statesmen confronted with similar problems.

That the great German writer on Political Economy, List, the intellectual founder of the German Zollverein and the author of A National System of Political Economy, published in parts from 1841 to 1846, was considerably influenced by Hamilton's teaching and policy, there seems little reason to doubt. At the instigation of 
General Lafayette, List visited the United States early in the nineteenth century, and in 1830 he was appointed by President Jackson Consul for the United States at Hamburg. It is thus evident that although he was not actually in the States until after Hamilton's death he was brought into intimate contact with that commercial policy of which Hamilton was the chief fornder. Moreover, it is impossible to read the arguments and general national policy advocated in List's book without being struck by their similarity to some of Hamilton's best known writings, as, for instance, Hamilton's famous "Report on Manufactures" submitted to the House of Representatives in 1791.

But whatever influence the teachings of Hamilton may have had upon List in the shaping of a German fiscal policy so closely resembling that of the United States, there is no doubt that in both countries the great instrument of Federation was a fiscal system of Free Trade between the Federated States and a general tariff as against the outside world. And with this policy of cementing Federation by national commercial arrangement the names of Hamilton in America and List in Germany must remain for ever associated.

It will now be of interest to consider more explicitly some of the problems and difficulties of the great task which Washington and Hamilton set before themselves after the Independence of America had been accomplished.

The Articles of the Confederation of the United States of America-" whereas it hath pleased the great Governor of the world to incline the hearts of the legislatures" of the different States to approve of, and ratify, the said articles-were only signed by delegates of all the States excepting Maryland in 1778, three years after the 
Declaration of Independence. The delegates of Maryland declined to sign until the year 1781. During this period and for many years afterwards troubles between the various States and the Central Congress rendered the work of confederation by no means easy. And it required all the tact and firmness of Washington, combined with the arguments and eloquence of Hamilton, to reconcile conflicting interests and gradually to establish that confederation on a sound and permanent basis.

The preamble to the Constitution of the United States runs as follows:-

"We, the people of the United States, in order to form a more perfect union, establish justice, insure domestic tranquillity, provide for the common defence, promote the general welfare, and secure the blessings of liberty to ourselves and our posterity, do ordain and establish this Constitution for the United States of America."

The spirit and intention of this Constitution, which the Preamble so well expresses, are, from a human and national standpoint, so admirable as to be worth retaining in the memory. And in the endeavour to attain as far as possible the fulfilment of this ideal for his country, Hamilton felt that every policy-fiscal or otherwise-must be subordinated. In considering the commercial policy which it was desirable and expedient for America to follow, Hamilton was not without the advantage of an intimate acquaintance with the Free Trade doctrine of Adam Smith. His book, The Wealth of Nations, had appeared in 1776, and we are assured by Mr. Oliver that "Hamilton had studied the book with care and had written a commentary upon it, which unfortunately has been lost".

In the year 1791 Hamilton submitted to the House of Representatives a "Report on Manufactures". In 
this document he shows the breadth and originality of mind worthy of a statesman loyal to that ideal so eloquently set forth in the preamble to the Constitution. The development of his country must be symmetrical and self-contained, not lop-sided and perilously dependent on conditions of international interchange, which war and other disturbing human factor's might at any moment dislocate. Wealth-regarded by Adam Smith as the sum of all the exchange values possessed by individuals in the State during a time of universal peace-was a desirable commodity enough, and the more of it the better, provided certain other qualities essential to the stability and welfare of the State were not sacrificed in pursuing it.

On this point Hamilton and List show themselves absolutely at one. Wealth without security and continuous productive power is a danger rather than an advantage. Hamilton, in writing on Political Economy, contrives to endow this usually dreary subject with the same fire and brilliance that Huxley displayed in his treatment of Natural Science. His writings would deserve perusal as specimens of vigorous English literature even if they possessed no other merit.

In the Report referred to he says :- -1

"Not only the wealth but the independence and security of a country appear to be materially connected with the prosperity of manufactures. Every nation, with a view to those great objects, ought to endeavour to possess within itself all the essentials of national supply. These comprise the means of subsistence, habitation, clothing and defence. The possession of these is necessary to the perfection of the body politic; to the

H. C. Lodge, Works of Alexander If tmilton, 1904, vol. iv., pp. $135-36$.

$$
4 \text { * }
$$


safety as well as to the welfare of the society. The want of either is the want of an important organ of political life and motion; and in the various crises which await a State it must severely feel the effects of any such deficiency. The extreme embarxassments of the United States during the late war, from an incapacity of supplying themselves, are still matter of keen recollection; a future war might be expected again to exemplify the mischiefs and dangers of a situation to which that incapacity is still, in too great a degree, applicable, unless changed by timely and vigorous exertion. To effect this change, as fast as shall be prudent, merits all the attention and all the zeal of our public councils : it is the next great work to be accomplished."

He also adds :-

"The want of a navy to protect our external commerce, as long as it shall continue, must render it a peculiarly precarious reliance for the supply of essential articles, and must serve to strengthen prodigiously the arguments in favour of manufactures."

The view so complacently held by Adam Smith and his followers, namely, that we should continue to be the workshop of the world, while the United States, our colonies, and all other new countries should be content to continue to supply us with food and raw materials in exchange for our manufactures, and should refrain from being so foolish as to attempt manufactures on their own account, did not at all appeal to Alexander Hamilton.

Thus he writes: - 1

"It is a just observation, that minds of the strongest and most active powers for their proper objects fall below mediocrity, and labour without effect, if confined to un-

${ }^{1}$ H. C. Lodge, Works of Alexander Hamilton, 1904, vol. iv., p. 93. 
congenial pursuits. And it is thence to be inferred, that the results of human exertion may be immensely increased by diversifying its objects."

A perusal of this Report shows how absolutely Hamilton realised the necessity of Protection to infant industries:- ${ }^{1}$

"Combinations by those engaged in a particular branch of business in one country, to frustrate the first efforts to introduce it into another, by temporary sacrifices, recompensed, perhaps, by extraordinary indemnifications of the government of such country, are believed to have existed, and are not to be regarded as destitute of probability. The existence or assurance of aid from the government of the country in which the business is to be introduced may be essential to fortify adventurers against the dread of such combinations; to defeat their efforts if formed; and to prevent their being formed, by demonstrating that they must in the end prove fruitless. Whatever room there may be for an expectation that the industry of a people, under the direction of a private interest, will, upon equal terms, find out the most beneficial employment for itself, there is none for a reliance that it will struggle against the force of unequal terms, or will, of itself, surmount all the adventitious barriers to a successful competition which may have been erected, either by the advantages naturally acquired from practice and previous possession of the ground, or by those which may have sprung from positive regulations and an artificial policy. This general reflection might alone suffice as an answer to the objection under examination, exclusively, of the weighty considerations which have been particularly urged."

The argument for the Protection of Infant Industries

${ }^{1}$ H. C. Lodge, Works of Alexander Hamilton, 1904, vol. iv., p. 39. 
was never more clearly or more conclusively stated. And it does suggest the reflection that if "positive regulations and an artificial policy " are capable of strangling an infant industry, they may also be capable of inflicting disastrous injury upon an adult one, and further that a modified and moderate measure of Protection against so specially directed an attack may be as desirable under these conditions for the injured adult industry as the more rigid form of Protection was for the infant one.

The Report goes on to urge that manufactures would attract emigrants and also foreign capital :-1

"It is a natural inference, from the experience we have already had, that, as soon as the United States shall present the countenance of a serious prosecution of manufactures, as soon as foreign artists shall be made sensible that the state of things here affords a moral certainty of employment and encouragement, competent numbers of European workmen will transplant themselves, effectually to insure the success of the design. How, indeed, can it otherwise happen, considering the various and powerful inducements which the situation of this country offers-addressing themselves to so many strong passions and feelings, to so many general and particular interests?"

In the same way he shows how the prospect of successful manufacturing industries will not only attract capital to the States but even induce manufacturers from Europe to plant factories there.

How amply Hamilton's anticipations on these vital points have been fulfilled, and how completely his policy has been vindicated, all those with any knowledge of the vast development of America's resources and industries

${ }^{1}$ H. C. Lodge, Works of Alexander Hamilton, 1904, vol. iv., p. 109. 
can testify. Variety of occupation and interests were essential in Hamilton's opinion to a healthy national development. And he continually refers to the point:-

"The spirit of enterprise, useful and prolific as it is, must necessarily be contracted or expanded, in proportion to the simplicity or variety of the occupations and productions which are to be found in a society. It must be less in a nation of mere cultivators than in a nation of cultivators and merchants; less in a nation of cultivators and merchants than in a nation of cultivators, artificers, and merchants." I

An all-round symmetrical development of a civilised nation's functions was in Hamilton's opinion essential for the welfare and stability of the State, and can any one who views the position of the United States to-day with her enormous system of railways, her colossal steel and other industries, and her abounding prosperity, question the wisdom of this policy not merely from a national and human but from an economic point of view?

To the writer who has visited the States on more than one occasion the fiscal and commercial policy so eloquently advocated by Hamilton, and so persistently followed by the States, would appear to be absolutely vindicated beyond any shadow of doubt. Vindicated by a century of the most remarkable and enormous material and economic development that the world has ever seen.

And yet we find even to-day men of distinguished position and ability, like Lord Avebury, apparently as strongly convinced of the opposite view as the most ardent of their Free Trade predecessors from Adam Smith and Cobden downwards.

${ }^{1}$ H. C. Lodge, Works of Alexander Hetmilton, 1904, vol. iv., p. 95 . 
Thus Lord Avebury, in the address already referred to delivered in $1908,{ }^{1}$ says :-

"We may regret that the United States, and our own colonies, instead of developing their enormous agricultural resources, have preferred to compete with us in the matter of manufactures. They have suffered very much from this short-sighted policy. If they had adopted a different course they would have made much more progress, and we should have shared in their prosperity."

Why Lord Avebury should think it necessary to suggest that the United States and our colonies have not adequately developed their agricultural resources, in view of the fact that the wheat from the millions of acres under cultivation in the States, Canada, and Australia has already reduced the cost of that commodity in these manufacturing islands to a cost considerably lower than anything ever contemplated by either Adam Smith or Cobden, it is difficult to understand.

Does he believe that if they had not "preferred to compete with us in the matter of manufactures," in the United States they would have had still more millions of acres under cultivation? Does he believe that under these conditions the population of the States would have approached its present proportions? If so, would it not have been an extraordinary phenomenon for a population of some $80,000,000$ people of European descent to have remained almost entirely dependent on agriculture, and dependent for obtaining their manufactured goods on exchanging the products of that agriculture with countries on the other side of the Atlantic? Could a community so circumstanced have been regarded as a stable

1 "Free Trade Address by Lord Avebury," p. 34. Published by the Cobden Club. 
and secure one? Would they not rather, as Hamilton foresaw, have been in constant peril of having their whole commercial and social fabric utterly deranged by such an incident as a war or even the hostile commercial action of European powers? Moreover, is it reasonable to suppose that a country with such magnificent mineral resources, such facilities for producing raw material like cotton, should remain for ever dependent on others for the manufactured products from these materials, even if at the outset some temporary sacrifice were made to acquire their industrial independence?

The whole conception seems so unreal that it is difficult to believe that Lord Avebury seriously entertains it. Yet in doing so he is only echoing the doctrines of the laissez-faire school and the "mazy" abstractions of the Cobden Club. But to turn from the visionary realms of a latter-day pseudo-Cobdenism to the region of actual fact, it is interesting to note still further some of the arguments used by Alexander Hamilton a hundred years ago ; to observe more explicitly how far his policy was put in force; to what extent it has been approved and is still approved by the American democracy; and finally, to consider the actual results, so far as they are ascertainable, produced in the United States by the practice of that policy.

As has been already pointed out, Hamilton was fully acquainted with the teaching of Adam Smith in his Wealth of Nations. But Hamilton, being a man of affairs and a constructive statesman engaged in moulding both the constitution and the future destinies of his country, felt little inclination to adopt the policy of laissez faire in any extreme form either in commerce or anything else. He had had too much experience of the real man to rely too implicitly on the collective result 
of the actions of a number of individual "economic men". For him these antomata, the laws of whose actions in the economic world could be expressed by algebraical or other formulæ, did not exist.

In his writings there is none of that obscurity of diction, so invariably the accompaniment of confusion of thought, which is only too frequently found in the writings of political economists, and which in a later day called forth the scathing denunciation of Jevons already referred to. ${ }^{1}$ Hamilton was an actor on the world's stage, as well as a writer. He was endowed in a remarkable degree with that perspicacity which, brushing all trivial and irrelevant matters aside, goes straight to the heart of the business in hand.

In considering the Free Trade policy of Adam Smith he was the last man to fail to see its attractiveness. But he was among the first to place his finger upon its great defect as a practical policy for all countries at all times. He was prepared to admit the wisdom of Free Trade upon one stipulation, and that was "if the system of perfect liberty to industry and commerce were the prevailing system of nations". Here in a nutshell is the answer to the Free Trade argument as a panacea. But as he points out: "The prevalent one has been regulated by an opposite spirit. The consequence of it is, that the United States are, to a certain extent, in the situation of a country precluded from foreign commerce. They can, indeed, without difficulty, obtain from abroad the manufactured supplies of which they are in want; but they experience numerous and very injurious impediments to the emission and vent of their own commodities. Nor is this the case in reference to a single foreign mation only. The regulations of several coun-

${ }^{1}$ Vide above, p. S. 
tries, with which we have the most extensive intercourse, throw serious obstructions in the way of the principal staples of the United States.

"In such a position of things the United States cannot exchange with Europe on equal terms; and the want of reciprocity would render them the victim of a system which should induce them to confine their views to agriculture, and refrain from manufactures. A constant and increasing necessity, on their part, for the commodities of Europe, and only a partial and occasional demand for their own, in return, could not but expose them to a state of impoverishment, compared with the opulence to which their political and natural advantages authorise them to aspire.

"Remarlss of this kind are not made in the spirit of complaint. It is for the nations whose regulations are alluded to, to judge for themselves, whether, by aiming at too much, they do not lose more than they gain. It is for the United States to consider by what means they can render themselves least dependent on the combinations, right or wrong, of foreign policy. . . . If Europe will not take from us the products of our soil, upon terms consistent with our interest, the natural remedy is to contract as fast as possible our wants of her." 1

Having thus clearly and dispassionately stated his views and defined his position, Hamilton came to the conclusion that "To produce the desirable changes as early as may be expedient may therefore require the incitement and patronage of Government ".2

The framers of the Constitution of the United States were at any rate determined that Congress should have a free hand in this matter. Thus Section 8 of Article 1

1 Oliver's Alexander Ilamilton, pp. 243-244.

${ }^{2}$ Ibid., p. 246. 
of the Constitution in brief but precise terms provides that: "The Congress shall have power to lay and collect taxes, duties, imposts and excise"-also further on in the same section-" To regulate commerce with foreign nations, and among the several States, and with the Indian tribes".

A perusal of the history of the United States discloses the fact that this power "to regulate commerce with foreign nations" has been freely exercised by Congress from the time the Constitution came into force down to the present day.

In this manner, then, the principles laid down by Hamilton have become part of the flesh and blood of the social and commercial fabric of the United States.

The means chiefly relied upon by the successive congresses to give effect to this policy has been a protective tariff levied upon manufactured imports.

A "Memorandum on American Tariffs" compiled by Mr. A. Mosely, and recently published, contains with admirable conciseness a record and history of the tariffs imposed from 1789 down to the Dingley tariff. And the memorandum is further prepared with the intention of throwing light upon " what effect the protective tariff has had in the building up of the astonishing state of prosperity that one sees in the United States to-day, both in the overwhelming increase of capital by her manufacturers, the great general prosperity, and the high standard of living of the masses ".

For the purposes of analysis and examination the memorandum divides the various phases assumed by the tariff into a series of periods. At the outset there was a period of low tariffs. But in 1807-8 the tariffs were materially raised, and in 1812 a war tariff was enacted which doubled existing duties. This tariff re- 
sulted in great activity in manufacture, the average rate on imports having increased to 32 per cent.

During the whole of the nineteenth century the protective tariffs were continued. At times, however, reactions against the tariff caused reductions to be made.

Thus in 1833 there was first put in force what was known as the "Compromise Tariff" under which reductions in the tariff were made annually by instalments. By the action of this law tariffs fell from their highest point in 1828, when they averaged 48 per cent., to an average of about 17 per cent. in 1842 .

The American writer Curtiss, in his History of Protection in the Unitsd States, associates all the periods of depression in that country with the reductions in the tariff, which, according to this writer, were the chief causes of these crises. Thus he says that a Free Trade or purely revenue tariffs period culminated in the year 1857, when the tariff was again revised and further reductions made. This is described as a "culminating Free Trade Act, resulting in panic and commercial ruin, the worst in the nation's history".

In 1860 Lincoln became president. In reply to a deputation desiring to know his views on fiscal policy he replied :-

"The problem seems to me a simple one. If we adopt Free Trade it means that we import our goods, in which case the foreigner will have the money and we shall have the goods. If we adopt a system of Protection-or better, a system of safeguarding our industries and our workmen-thereby manufacturing the goods ourselves, the result will be that in so manufacturing we shall have both the goods and the money."

The Lincoln tariff, besides increasing the existing

1 "Memorandum on American Tariffs," by Mr. A. Mosely, C.M.G. 
duties, introduced for the first time a new principle. It changed many duties from being merely ad volorem to a specific character. Lincoln's schedule, passed on these scientific lines, remained practically in force till 1882, when the Tariff Commission of the United States was appointed. It is significant to note that the discriminating and scientific character of the Lincoln tariff was, after twenty-two years' trial, approved and still further extended by this Commission.

In their report the Commissioners state that "Its framers regarded all forms of American labour, and placing a duty upon the primary element of an article if of native production, advanced the rate as the article was advanced by the increased expenditure of labour". And later on, they say, "While aiming to diminish the burdens upon the people which inevitably attend any system of collecting the national revenue, the Commission has not lost sight of the relations of a wise tariff system to the attainment of the highest possible material life of the nation; its security in times of war, both in its means of defence and industrial independence; its position amongst the nations; its acquisition of all the arts which fortify, enrich and adorn; its attractiveness for the skilled labour of other lands, and the comfort and means of all its people". ${ }^{1}$

This paragraph breathes the spirit, and might indeed have been the ipsissima verba of Alexander Hamilton, so like is it both in style and manner to his writings on fiscal policy. The work of this Commission resulted in the readoption of a tariff arranged on scientific protectionist lines.

A reaction against the tariff occurred in 1881, but the Morrison Bill, intended to reduce it, failed. In 1890 the

'Mosely's "Memorandum on American Tariffs." 
McKinley Bill was introduced, and in meeting the arguments against Protection President McKinley said:

"First, then, to retain our own market under the democratic system of raising revenue by removing all protection, would require our producers to sell at as low a price and upon as favourable terms as our foreign competitors. How can that be done? In one way only: by producing as cheaply as those who would seek our markets. What would this entail? An entire revolution in the methods and conditions and conduct of business here, the levelling down through every channel to the lowest line of our competitors; our habits of living would have to be changed, our wages cut down 50 per cent. or upwards, our comfortable homes exchanged for hovels, our independence yielded up, our citizenship demoralised. These are the conditions inseparable to Free Trade; these would be necessary if we would command our own market among our own people; and, if we would invade the world's markets, harsher conditions and greater sacrifices would be demanded of the masses. Talk about depression! We would then have it in its fulness! We would revel in unrestrained trade! Everything would indeed be cheap, but how costly when measured by the degradation which would ensue! When merchandise is the cheapest, men are the poorest, and the most distressing experiences in the history of our country-aye, in all human history-have been when everything was the lowest and cheapest measured by gold, for everything was the highest and dearest measured by labour. We want no return to cheap times in our country. We have no wish to adopt the conditions of other nations. Experience has demonstrated that for us and ours, and for the present and the future, the protective system meets our wants, our con- 
ditions, promotes the national design, and will work out our destiny better than any other. With me this is a deep conviction, not a theory. I believe in it, and thus warmly advocate it because enveloped in it are my country's highest development and greatest prosperity. Out of it came the greatest gains to the people, the greatest comforts to the masses, the widest encouragement for many aspirations, with the largest rewards, dignifying and elevating our citizenship upon which the safety and purity and permanency of our political system depend."

In 1894 the Wilson tariff-with strong Free Trade tendencies-was adopted. In 1897, after a period of extreme depression, the Dingley Bill on the lines of the McKinley tariff was passed. It increased some duties and modified others to suit the changed conditions of the time, and has remained in force ever since.

While it is probably somewhat overstating the case to contend, as Mr. Curtiss and Mr. Mosely are disposed to do, that every commercial crisis in America has been brought about entirely by a reduction in the tariffs, the converse of this proposition will be found very difficult to refute. The adoption and maintenance of a protectionist policy ever since the time of Lincoln which has tended, with the exception of the Wilson tariff in 1894, to become more specifically and scientifically protectionist with each revision down to the time of the Dingley tariff in 1897, has undoubtedly been accompanied with phenomenal advancement in industrial and general prosperity. If, as Cobdenite free traders of Lord Avebury's opinion would apparently argue, this prosperity has been won by a country richly endowed by nature with resources, in spite of Protection, it will have to be conceded that the people of the United 
States themselves are not of that opinion. After a period of wavering and uncertainty on the question of fiscal policy in the earlier half of the nineteenth century, in which several low tariff periods were tried, they have declared unhesitatingly in frequently recurring triennial periods at the polls in favour of Protection.

That there may be in the future as there have been in the past reaction and modification of the tariff in the direction of Free Trade is more than probable. But that the present policy of Free Trade between the States uniting them in a common bond, and Protection as against the outside world, will ever be departed from except on Hamilton's supreme condition of universal Free Trade, there is not a tittle of evidence to suggest.

Free Trade-in its true sense of free exchange-not in the false one-sided sense of free imports only-is a privilege the Americans reserve for their own citizens which foreigners may not share. It is the privilege of every citizen, and, supplemented as it is with a tariff against the outside world, is a great federal link binding the various States of the Union together.

Although in the latest great Federation, that of Great Britain and her colonies and dependencies, Free Trade may not yet be obtainable, Freer Trade than at one time existed has already been obtained between Colonies and Mother Country-by a reduction of Colonial tariffs in favour of Great Britain-as a privilege for Imperial citizens. If this treatment be reciprocated by Great Britain, it will doubtless be still further extended by the Colonies. And this preferential Freer Trade will serve the cause of federation in the British Empire as privileged Free Trade has served it in Germany and the United States. 
It would scarcely be doing the subject of this chapter justice if it were concluded without reference to the extraordinary progress that has been made, under the influence of a scientific tariff, in the United States in certain specific industries. In the quinquennial period from 1876-80 the average production of steel in the United States stood at 800,000 tons. In 1907-that is some fifteen years after the Tariff Commission's recommendations were embodied in a revised scientific tariff -this production stood at 23 million tons, or more than the steel produced in England and Germany put together.

In the period 1883-87 the average annual consumption of raw cotton in the States amounted to 999 million pounds. In the period 1903-7 this average had risen to 2,312 million pounds, being an excess of 526 million pounds over the average of the United Kingdom for the same period (vide table, p. 25).

These figures with reference to the enormous growth of the iron and cotton industries in America are more instructive than the returns only of imports and exports on which so many writers appear to believe the verdict with regard to the industries of a country must almost entirely depend. What is so frequently overlooked in estimating the industrial position of any country-and especially of the United Kingdom-is the immense importance of the home market. This home market the United States secures very largely to herself under her tariff system, and it is this security which has enabled these two industries to develop such colossal proportions.

Is it possible that Lord Avebury was familiar with these figures when, early in the year 1908, he said as already quoted-speaking of the American system of Protection-" They have suffered very much from this short-sighted policy"? 
If to employ a larger number of workmen at a higher rate of wages, to offer a greater prospect of advancement to individuals, to increase more rapidly in material wealth and in numbers, than any other country, either now or in any former time, on the face of the globe, be suffering, then the United States have indeed suffered heavily.

But if, on the other hand, these accomplishments do, as the great majority of mankind believe, indicate progress and prosperity, then the United States have gone far and abundantly prospered.

Nor is it conceivable that any impartial student of this prosperity whose vision is not obscured by the mists of bygone doctrinaire hypotheses can for one moment hold with Lord Avebury that "If they had adopted a different course they would have made much more progress. . . ." 


\section{CHAPTER V. \\ GERMANY AND HER CUSTOMS UNION.}

The Holy Roman Empire-Modern German Empire-Its Federal character-The wars of Prussia-The Zollverein an instrument of Federation-List's National System of Political Economy-His estimate of England's position in 1844-Free Trade in Germany-The Continental blockade-The work of the Zollverein-Estimates of List and Mill on the effects of Protection in America-Bismarck's Free Trade era-His return to Protection-State Workmen's Insurance-Emigration from Germany and Great Britain-Socialism-Universal military training.

To understand the position, the political and economic structure, and the aspirations of the Modern German Empire, requires at least some knowledge and study of that remarkableinstitution of the middle ages-which was only finally dissolved in 1806-the Holy Roman Empire.

This Empire, in which were blended the Teuton and the Roman, the greatest temporal and the greatest spiritual powers, which dominated the continent of Europe for over a thousand years, combining as it did the influence of the popes with the material strength of powerful rulers, has a history which is full of strife and of suffering, of heroism and martyrdom, of intellectual advancement and of blind superstition, of all the brilliant and all the obscure incidents which have gone to make up a large portion of the drama of the evolution of Western civilisation. 
In referring to it there is but one consideration which calls for some examination here. It is the conception and the nature of the Empire which thus subsisted through the long ages of the mediæval twilight down to and beyond the period of the European Renaissance.

It is true that from the Reformation onwards the Empire gradually waned until in the eighteenth century Voltaire declared that it was neither holy, nor Roman, nor Empire; but although but a gaunt shadow of its former self, it did not actually cease to exist until the year 1806 .

What then in essence was this Mediæval Empire? It was in its earlier years the continuance in spirit and form of that system which the Cæsars imposed upon the ruins of the Roman Republic. It was based upon usurped authority and tradition which frowned on individual liberty and private judgment alike. No matter what ferocity or tyranny might rend the civic life, the ruler's were ordained of God.

This system engendered in its Emperors a passion for aggressive dominion over all the earth. This system, in its turn, inspired Napoleon, and has made the very terms, Empire and Imperialism, terms of such reproach that to this day they are intolerable to many men of democratic opinion. It proved a source of feud to central Europe for ages. Under Napoleon it destroyed the power and half the manhood of France.

If, therefore, Empires and Imperialism are to persist and flourish in the future it must be on different lines from these. And of this fact not even the supporters of the present British Empire have shown a greater consciousness than some of the builders of Modern Germany.

Thus in a controversy-to which Mr. Bryce refers in his most interesting and brilliant work The Holy 
Roman Empire-which took place under the present German Empire, the spokesmen of the Austrian Roman Catholic party claimed for the Hapsburg Monarchy the honour of being the representative of the Mediæval Empire, and urged that only again by accepting this leadership could Germany have restored to her, her former strength and glory. This evoked from certain North Germans the following bitter retort:-

"Yes," they replied, "your Austrian Empire, as it calls itself, is the true daughter of the old despotism; not less tyrannical, not less aggressive, not less retrograde; like its progenitor, the friend of priests, the enemy of free thought, the trampler upon the national feeling of the peoples that obey it. It is you whose selfish and antinational policy blasts the hope of German unity now, as Otto and Frederick blasted it long ago by their schemes of foreign conquest. The dream of Empire has been our bane from first to last." 1

Whether or no this last utterance contains any moral for Modern Germany, one thing at least is certain, the German Empire of to-day is built on very different lines to the Empire of the past. What that difference is, and how it has been brought about, call for our careful consideration.

In 1806 the old Empire was buried. Fifty years later the Modern German Empire arose like a Phœnix from its ashes, and with all its modernity the onlooker may sometimes imagine that he discerns occasional lurid flashes of the old nether fires. Nevertheless modern, scientific, and even democratic it is. No European State to-day approaches so closely in many respects the great democracy of the United States. In both cases the constitution is a federal one. In addition to

${ }^{1}$ Bryce's Holy Roman Empire, p. 367. 
the powerful Kingdom of Prussia, the German Empire contains monarchies such as Bavaria, Saxony and Würtemburg, as well as small republics such as Hamburg and Bremen. Each has its own local government and peculiar constitution. Some are Protestant and some are Roman Catholic. And yet in questions of international relationship, whether of defence or fiscal policy, the federal Government is supreme-with a solidarity, uniformity and power-which no heaven-appointed emperor under the Mediæval Empire was ever able to attain.

What, then, were the forces productive of this result?

It is the habit of historians in dealing with this period to attribute the solidarity which Germany has attained in the last quarter of the last century to the influence of war, and the powerful headship of the Hohenzollern family. And doubtless the influence, both of the Austrian and the Franco-Prussian Wars, was to sweep away many old-standing differences between the feudal and liberal parties in Prussia, and to go far to arouse a new national spirit. But Central Europe has a history of wars almost unceasing behind it, and in spite of the nominal existence of the Holy Roman Empire, the great historic Federation of the middle ages, over so long a period of time, war cannot be said to have proved very reliable as an instrument of Federation.

It is worthy of note that even after the death of the old Empire, there arose at the time of the Napoleonic Wars another Germanic Confederation including Austria as well as Prussia and the other German States, which lasted down to the time of the quarrel over the annexation of Schleswig-Holstein. At this juncture Prussia stood almost alone. Then followed war with Austria in 1866, and here war proved a two-edged sword to the Confederation, for if it consolidated the rest of Germany 
it cut off Austria, and excluded her from the Confederation.

In 1870, as an outcome of the Franco-Prussian War, the Imperial Crown was once more placed upon the head of a German potentate. The King of Prussia became German Emperor. But Austria remained outside the new Imperial Federation, and with her some seven million Germans. Nevertheless, under a new constitution the Empire was restored, and it undoubtedly to-day possesses more power, organisation, and stability as a political organism than could at any time be found in its mediæval predecessor.

Turning from these rapid and dramatic changes, surrounded as they are with all the glamour of a new Imperial dynasty, and all the pomp and panoply of war, it is interesting to observe and record what other movements, what undercurrents, perhaps less apparent but none the less powerful, contributed to the building of this new State. In the interval between the old Empire in 1806, and the new Empire in 1870, a period of sixtyfour years, certain changes, but little marked by the historian, and less picturesque and attractive to the general reader than the foundation of new dynasties, were taking place within the kingdoms and petty principalities of the German Confederation.

In the first place there existed in Germany, especially in the Northern States, in common with the rest of civilised Europe, the political spirit of the nineteenth century, a spirit which combined with the desire for individual liberty the aspiration towards national unity. The progressive party, while it championed the cause of the people, saw also in national unity, on rational and constitutional lines, the future welfare of the people.

It was to men in this mood that List's policy of the 
Zollverein or Customs Union appealed. List realised, and eventually taught his countrymen to realise, that the most powerful federal and national instrument which the world could use to-day, an instrument more powerful than any treaty, or the prestige of any potentate, was that of mutual and permanent self-interest. States varying in religion, in their allegiance to different reigning houses, and in other divergent interests, might be brought very closely together by establishing a common commercial and industrial policy.

Mediævalism died with the old Empire. The world was entering on a new era. And as Napoleon said at the beginning of the century, "Formerly there was but one description of property, the possession of land; but a new property has now risen up, namely, industry."

The United States anticipated the German States in adopting a policy of Free Trade within its borders and protection without as a federal instrument. What Alexander Hamilton pleaded for with such power and eloquence, what the North Americans subsequently fought for, was very largely the policy which List introduced to his countrymen.

In 1815, at the close of the Napoleonic Wars, the continental blockade system, under which Germany had felt the advantage of Protection in many of her manufactures, came to an end. German ports were thrown open to foreign manufactured imports at low rates of duty, but custom-houses continued to gather duties on the frontiers of all the petty German States from one another. An association, formed to promote the abolition of these internal barriers to trade, elected List as its president. His election to this office, which was disapproved of by the Government authorities, cost List his official appointment in the civil service of Würtemburg, 
and eventually led him to seek his fortunes in America. While there he made the acquaintance of General Lafayette, President Jackson, Henry Clay and other leading spirits of the United States. His stay in America, where he was successful both in journalism and industrial enterprise, doubtless tended to strengthen his belief in the national and federal value of Free Trade within the national territories, and a Protective tariff outside. On his return to his native country he returned with renewed vigour to the task of converting his countrymen to his views.

In 1841 appeared the first part of his National System of Political Economy-the fourth part entitled The Politics being published in 1844 . The avowed object of this work was to advocate a policy for uniting Germany by a Customs Union or Zollverein embracing all the different States, in other words to do as the United States had already done, to allow no duties within the Federation but to maintain and develop them without. Free Trade for the home manufacturer within his own domain-restricted trade for the foreign competitor.

A nation without great productive industries of its own, dependent for the bulk of its manufactured supplies on other countries, was no more acceptable to List than it had been to Hamilton, however much such a scheme might commend itself to the English free traders writing avowedly in the broad interests of mankind at large, but really, as List stoutly maintained, on behalf of their country, then the workshop of the world.

At the time List wrote his book the Free Trade doctrines of J. B. Say and Adam Smith had been for some time before the world and had attracted many followers. In meeting them List had no difficulty in showing 
how unuch the policy by which England had risen to greatness differed from the teachings of these writers.

Thus he pointed out that in 1721 the English King was made, by his ministers, at the opening of Parliament, to say that "it is evident that nothing so much contributes to promote the public well-being as the exportation of manufactured goods and the importation of foreign raw material". ${ }^{1}$

In order to carry out this policy, England-as List points out-in addition to her undoubted conquests in science and the arts, resorted to Navigation Laws, Commercial Treaties, and wise and powerful protection extended to her home industries. According to the Free Trade theorists England had attained to wealth and power, not by means of, but in spite of her commercial policy. "As well," says List, "might they argue that tree have grown to vigour and fruitfulness not by means of, but in spite of, the props and fences with which they had been supported when they were first planted." ".

The estimate which List gives, at the time of writing his book, of the power and resources of England is most instructive, and is of special interest as describing the position of England previous to the commencement of her Free Trade era. And on the necessity of power as an accompaniment to wealth, List is the most emphatic of all the writers on Political Economy. Thus he writes :-

"Power is more important than wealth. And why? Simply because national power is a dynamic force by which new productive sources are opened out, and because the forces of production are the tree on which wealth grows, and because the tree which bears the

${ }^{3}$ List's National System of Political Economy, p. 32.

${ }^{2}$ Ibid., p. 33. 
fruit is of greater value than the fruit itself " ... . and because the reverse of power-namely, feeblenessleads to the relinquishment of all that we possess, not of acquired wealth alone, but of our powers of production, of our civilisation, of our freedom, nay, even of our national independence".

Summing up England's position he says :-

"England has got into her possession the keys of every sea, and placed a sentry over every nation. . .." "Her navy alone surpasses the combined maritime forces of all other countries, if not in number of vessels, at any rate in fighting strength. . .." "Her manufacturing capacity excels in importance that of all other nations...." "In the fourteenth century England was still so poor in iron that she thought it necessary to prohibit the exportation of this indispensable metal ; she now, in the nineteenth century, manufactures more iron and steel wares than all the other nations on earth." 1

If that was so in the forties of the last century, a period within the life of many now living, it is significant to note the change that has since occurred. The views of List have prevailed. The Zollverein policy, abolishing all customs within the Empire and thus extending wide the home market, and at the same time following England's old example, protecting that home market by tariffs against foreign competition, has been adopted. Under this policy what has happened to the iron and steel industries of Germany?

In 1907 Germany surpassed us considerably in the production of pig iron, and doubled our production of steel (vide table, p. 25). If ever facts appeared to justify and vindicate the contentions of a political writer assuredly they do so in the case of List.

${ }^{1}$ List's Nutional System of Political Economy, pp. 37, 38 and 39. 
List reviews and analyses at some length the history and fiscal policy of Germany down to and after the final adoption of the Zollverein. Prussia, first under Frederick II., seriously and systematically endeavoured to develop the agricultural and manufacturing resources of the country, using a protective tariff among other measures, as a means of doing so. Meanwhile the whole of Germany for centuries, with the exception of Prussia, had been and remained practically Free Trade down to the time of Napoleon's Continental blockade.

"It cannot, however," says List, "be asserted that the predictions and the promises of the school about the great benefits of Free Trade have been verified by the experience of this country, for everywhere the movement was rather retrograde than progressive."

With regard to the Continental blockade, ${ }^{1}$ maintained - so far as was practicable by Napoleon- List insists that there is abundant evidence to show in the statistical writings of the day that, as a result of the blockade, German manufacturers were materially benefited.

But on peace being re-established, British manufactures were again poured into the country, making great havoc among the native German industries. Even the

${ }^{1}$ Napoleon having overrun and imposed his authority upon most of Continental Europe, and being desirous of crushing England by means of crippling her trade, issued a decree forbidding any of the countries in his grip to import English goods. He also got Russia to agree to forbid such importation. The effect of this decree to the extent to which it was efficacious, was to "protect" such home manufactures as existed in the several European countries, though where none existed it caused curious results, English goods being very largely smuggled instead of openly imported into these countries. And incidentally it may be stated that Russia's breach of her promise to exclude British goods led to war with Napoleon, and was the beginning of his downfall. 
Prussian bureaucracy of the day became imbued with Adam Smith's writings and modified their tariffs in the direction of Free Trade. Great distress and outcry prevailed in the manufacturing districts. England was accused of "dumping" with a view to killing German industry, and Henry Brougham was reported to have said in 1815 "That it was well worth while to incur a loss on the exportation of English manufactures in order to stifle in the cradle the foreign manufactures".

Under the stress of this agitation Prussia soon returned to her protective policy. But at this time duties were levied at custom-houses between the different German States. And the smaller States now had to face not only exclusion from the markets of Austria, France, and England, but also from Prussia, which practically hemmed in several of them. "Restricted on all sides, in their export trade to small strips of territory, and, further, being separated from one another by smaller internal lines of customs duties, the manufacturers of these countries were well-nigh in despair."

It was to remedy this state of things that a Manufacturers' Union with branches throughout Germany was formed in 1819. Deputations visited every German Court, the work of the Zollverein began in earnest. A union was first formed between Würtemberg and Bavaria, then with some of the German States and Prussia, then between the middle German States; finally, there occurred a fusion of these three groups into a general Customs Union which comprised the whole of Germany except Austria, Hanover, the Hanse Towns and the two Mecklenburgs. Trade within the union was free and unrestricted, but as against the outside world a moderate protectionist tariff was maintained. 
Writing in 1841, List was able to record that "in consequence of this unification of customs, the industry, trade, and agriculture of the German States forming the union have already made enormous strides". From that time forward - with a slight and somewhat disastrous interval of modification in the direction of free imports under the influence of the Cobdenite agitation-this policy has been followed in Germany.

List's personal acquaintance with the institutions and fiscal policy of America had undoubtedly largely influenced him in his advocacy of the Zollverein policy. In his book he shows clcarly that he had closely studied the history of the trade and industry of the United States. He had noted the periods of Free Trade and Protection in that country and their consequences. And at a time, only some four years previous to that at which John Stuart Mill regarded Protection in America as a fiscal error from which that country was about to shake itself free, List pointed out that the Americans had realised the truth that proximate material advantages must not be the only consideration of a great nation. That, they saw that civilisation and power could only be secured and maintained by a symmetrical development of their country, in which the creation of manufacturing power was an absolutely essential factor.

With regard to their being reconciled-as Lord Avebury ${ }^{1}$ believes they should have been-to simply becoming one vast agricultural community, List showed a deeper insight. Thus, dealing with this point, he says :-

"It is even conceivable that, were the whole territory of the United States laid under cultivation from sea to

${ }^{1}$ See above, p. 56. 
sea, covered with agricultural States, and densely populated in the interior, the nation itself might nevertheless be left in a low grade as respects civilisation, independence, foreign power, and foreign trade." 1

It is thus evident that List's study of America and American industrial policy at first hand, had left a deep impression upon him. His estimate of its value and efficacy has been abundantly justified by results. Finally, it was largely on the great object-lesson afforded him by America that his advocacy of the Zollverein policy, which has in its turn proved of such immense value to Germany, was based. At the same time it would be a mistake to suppose that the Zollverein policy-in so far as it was protectionist against the outside world-has not had its opponents in Germany, or that it has even been rigorously and persistently adhered to by the German Government.

About the middle of the century, under the influence of the Cobdenite doctrines, and the policy of free imports which England had then adopted, a revision of the German tariff in the direction of free imports appears to have been made. And between the years 1865 and 1877 a series of measures of this character was passed. In 1878 the Free Economic Union agitated for a reversion to the earlier policy, on the ground that hostile tariffs and competing imports were causing the greatest depression both in trade and agriculture. In $1879 \mathrm{Bis-}$ marck avowed his intention to return to the timehonoured ways of 1823-65- "I am willing to confess my past errors".

In this same year a speech from the throne contained the following words: "I regard it as my duty to adopt measures to preserve the German market to national ${ }^{1}$ List, p. 84. 
production so far as is consistent with the general interest; and our customs legislation will accordingly revert to the tried principles upon which the prosperous career of the Zollverein rested for nearly half a century, but which have in important particulars been deserted in our mercantile policy since $186.5 . "$

In that same year, 1879, the Reichstag adopted a strong protective tariff. From that date onwards the tariff has been readjusted from time to time, but its Protectionist character has been scientifically differentiated and accentuated rather than relaxed. The reform duties of 1879 placed import duties on corn, wood and iron. In 1881 the two great ports of Hamburg and Bremen were brought into the Zollverein, which was thus made universal within the Empire and complete.

Turning to the progress which Germany has made since the completion of the Zollverein, there is no doubt that, judged by any reasonable standard of comparison which may be selected, she has advanced more rapidly and more materially than any other country except the United States. The increase in her production of pig iron and steel alone has never before been approached by any other country in the world, and has only been surpassed in the same period by the United States.

Her exports have increased both in actual amount and percentage to a much greater extent than the exports of Great Britain. ${ }^{1}$

\section{${ }^{1}$ Export Traje of Privcipal Countries.}

The following tables are taken from the Statistical Statements prepared by the Board of Trade and laid before the Colonial Conference of 1907 (Cd. 3524, page 310) :- 
The amount assessable for income tax in Prussia has increased in the ten years from 1896 to 1906 by 71 per cent., whereas that of England has not increased by more than a third of that percentage. ${ }^{1}$

Unemployment has existed for 1907 and 1908 to a much greater extent in England than in Germany.

On the other hand emigration from Germany, ${ }^{2}$ which at one time was very considerable, annually, has sunk to an insignificant amount, while emigration from England has been largely and rapidly increasing.

Added to all this are the significant and important

TOTAL SPECIAL EXPORTS

(i.e., manufactures and produce of the countries mentioned).

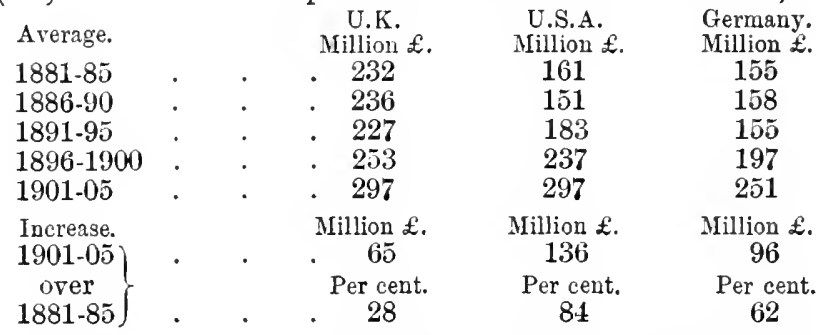

1 Report on Trade of Germany for 1906 by Consul-General Schwabach.

2 Thus taking the ten years' period from 1897 to 1906 , the annual number of emigrants has never exceeded 33,824 , or at the rate of 6.4 per 10,000 ; while in 1906 it stood as low as 4.3 per 10,000 . Yet in the eighties German emigration frequently stood at a rate of over 20 per 10,000. During the same decade British emigration never fell below $11 \cdot 3$ per 10,000-which point was touched in 1899 . And from that year onwards it steadily rose to $44^{\circ} 6$ per 10,000 in 1906. While in the year 1907 the greatest number ever recorded, 235,392 emigrants, left British shores, being at the rate of 50 per 10,000 . Of these it is some consolation to know that more than half went to some portion of the British Empire, but the remainder which went to foreign countries far exceeded in number those leaving the much larger population of Germany. 
facts that every German is trained as a soldier, and that Germany already has, and is rapidly increasing, a powerful fleet of modern battleships.

If List were alive to-day he would have the profound satisfaction of seeing that the fiscal policy for which he pleaded has been carried out to its fullest extent, and that the position in which Germany now finds herself is at least what he urged would be the result. Wealth in abundance, but not wealth alone, wealth with immense power for peace or war. A great home market in which the home producers are considered before the foreign producers, and are considered equally with the home consumers. By this means is productive power, which from a national point of view List always regarded as an essential portion of real wealth, developed and secured.

A study of the history of Modern Germany will convince any impartial reader that from the time when Bismarck, shaking off the last trace of Cobdenite influence, recanted and avowed himself a Protectionist, from the time when the Zollverein policy was completed and the spirit of it in List's sense of the word was allowed full sway, the progress of Germany has been phenomenal.

From 1879 onwards the last trace of the laissez-faire doctrines was thrown to the winds. Whatever was done was done not in deference to any shibboleth, or to any body of mazy abstractions, but on a cool, clear calculation of the probable results, and of their ultimate national value. For the inauguration of such a policy Bismarck was no doubt pre-eminently fitted. But for the driving-force behind him, at least in the fiscal portion of his policy, he was indebted to a determined Economic Union of Germans, who had by practical experience 
convinced themselves of the soundness of List's teachings. Whatever was done was thorough, calculating, and scientific. If Germany had dreamed in the past, she was awake and practical now.

In social reform Germany was no less thorough and scientific than in her military and fiscal policies.

In 1881, the very year in which the Zollverein was completed, was inaugurated the most remarkable and most successful piece of Social Reform that the world has ever seen, State Insurance for all German workmen. Under this scheme a central national fund is provided-to which contributions are made by the employer, the workmen, and the State-and out of which provision is made in the case of sickness, accident, invalidity, and old age. ${ }^{1}$ As a supplement to the scientific tariffs of 1879 and the eighties it has undoubtedly proved of immense value to the State.

For many years the Social Democrats had been a factor to be reckoned with. They were numerous and not without influence in the reign of William $I$. The State grappled with Socialism as it had grappled with war and with industry. Instructed by a definite message from the Throne, the Reichstag passed the State Workmen's Insurance Scheme. The practical effect of this measure has been to reconcile Socialists very largely to the existing order of things and to give them a stake and a participation in the wellbeing of the country which has largely increased their national interest and checked emigration.

Germany viewed as a whole to-day is a compact, symmetrical, powerful, wealthy and highly developed

${ }^{1}$ See Appendix for Report of Author's visit with delegates from Friendly Societies to inspect the Arrangements for State Insurance of Workmen in Germany. 
national organism, effective, progressive and prosperous in peace; ready and formidable for war, should war arise. If seventy years ago List did not hesitate to urge upon his countrymen that they had much to learn from England, assuredly the time has come when we in our turn may, with every advantage to ourselves, study and reflect upon the progress of Germany.

The three prominent factors in the position of the German Empire to-day are undoubtedly the Zollverein, combined with Protection against the outside world, the State Workmen's Insurance, and universal military training, and although the Constitution of the British Empire is such that no one of them may be applicable in its entirety to our requirements, there is much in each of them that we should be wise to adopt. 


\section{CHAPTER VI.}

GREAT BRITAIN BEFORE FREE TRADE.

The industrial development of England-Sheep-raising-Wool-

Woollen manufactures-Early measures of Protection-The cotton industry-The Methuen Treaty, 1703-The views of Adam Smith and List on the effect of this Treaty-Shipping and Navigation Laws-Infant and injured industries.

IT is undoubtedly a matter for considerable regret that, in an age when education for all classes of the community is being made a subject of special concern both to the State and to individuals, the industrial history of England should be so little taught either in our higher schools or universities. Yet the industrial development of England has probably been more potent in building up the British Empire than either the forces of feudalism or the wiles of politicians. In fact J.W. Welsford, in his brilliant and instructive work The Strength of Nations, has gone the length of saying that: "The Spanish Armada was defeated, and the battle of Trafalgar won, in the weaving sheds of England ". 1

If hitherto the attention of students of history and economics has not been sufficiently drawn to this subject, we are at least fortunate in possessing a comprehensive work by Dr. Cunningham entitled The Growth of English Industry and Commerce in Modern Times, in which

${ }^{1} \mathrm{~J}$. W. Welsford, The Strength of Nations, p. 141. 
the whole subject is dealt with in a spirit of impartiality and scientific research. It would be an excellent thing if all students of Political Economy, as set forth by the academic exponents of the laissez-faire school, were to acquaint themselves with this work.

A perusal of the main features of British industrial history establishes one fact beyond all question of controversy - the industries of England were born, nursed, and developed to a position supreme above those of all other nations under a system of deliberate and systematic Protection. A consideration of these facts, although it must of necessity be far from exhaustive, will enable us the better to understand the British Free Trade era and the present industrial and Imperial position.

For a considerable time after the Norman Conquest the main meat supply of England was furnished by pigs, and the breeding of hogs, which roamed and fed over the unenclosed forest lands, was one of the principal industries of the country.

But as the cloth weavers of the Continent increased their demands for wool, sheep-rearing gradually increased and came to be more important than the rearing of hogs. And to take one instance alone, in the year 1327 "Lord Spencer counted, upon sixty-three estates in his possession, 28,000 sheep". 1 The production of wool, although it furnished raw material for another industry, did not of itself create that industry, and the history of how the weaving of wool was first established as a staple British industry is significant and instructive.

On the subject of British capacity and natural aptitude for the introduction of manufacturing industries, Professor Thorold Rogers says: "That we learned all

${ }^{1}$ Hume, vol. ii., p. 143. 
our knowledge of weaving from the Flemings is certain, but we were the slowest of pupils. Even in the middle ages it was seen that a piece of cloth was worth at least eight times as much as the wool from which it had been spun and woven, and that, if we could catch the art, the wool which bore an export duty of 100 per cent. with ease, i.e., without depreciation, would have borne in the shape of cloth a far higher duty, and, in the absence of duty, a far higher profit. We had extraordinary advantages of climate, but we either did not understand them, or made no use of them. As I have told you before, I do not detect any progress in the arts of invention, under which the process of production was cheapened, for centuries, except in two arts, paper and glass-raaking. I do not know whence these arts were derived, and how they were improved. But I am sure they were both of foreign origin, and that their development in England was not due to native ability or to native enterprise." 1

It is evident that the British race had no special bent towards manufacturing industry, and that unaided such industry could scarcely have come into existence. In the time of Edward III. heavy export taxes were placed on wool, and taxes were also levied upon the foreign merchants trading in woollen goods from the Continent. In this way the "infant industry" of woollen manufacture was strongly protected and eventually grew to large proportions. By the middle of the fifteenth century England no longer sold wool-she sold only the cloth made from wool.

In the time of Elizabeth ${ }^{2}$ large quantities of undressed and undyed cloth were carried to the Continent to re-

1 Thorold Rogers, Economic Interpretation ofHistory.

${ }^{2}$ Welsford, Strength of Nations. 
ceive those finishing processes in which alum was such an important ingredient. Then alum was discovered in Yorkshire. The exportation of undressed and undyed cloth was prohibited, and the secondary cloth-making industry was established in England as the primary one had been. In the time of James I. the export of woollen manufactures had come to represent nine-tenths of all the English exports put together.

In relation to the early days of this industry in Great Britain, List writes :-

"This branch of manufacture enabled England to drive the Hanseatic League out of the markets of Russia, Sweden, Norway and Denmark, and to acquire for herself the best part of the profits attaching to the trade with the Levant and the East and West Indies. It was this industry that stimulated that of coal mining, which again gave rise to an extensive coasting trade and the fisheries, both which, as constituting the basis of naval power, rendered possible the passing of the famous Navigation laws which really laid the foundation of England's maritime supremacy. It was round the woollen industry of England that all other branches of manufacture grew up as round a common parent stem; and it thus constitutes the foundation of England's greatness in industry, commerce and naval power." 1

There were doubtless other factors in the development of this and other industries which enabled England to reap the fruits of Protection. Religious persecution under Philip II. and Louis XII. drove skilled artisans to Great Britain who were invaluable in introducing many new branches of industry. But the fostering of these industries by prohibitions and duties alone enabled them to be successfully started. "The island kingdom bor-

${ }^{1}$ List, National System of Political Economy, p. 31. 
rowed from every country of the Continent its skill in special branches of industry, and planted them on English soil, under the protection of her customs system. Venice had to yield (amongst other trades in articles of luxury) the art of glass manufacture, while Persia had to give up the art of carpet weaving and dyeing."

In the same way the Lancashire cotton industry was first started under Protection and received great advantages from preferential treaties and prohibition of imports. Thus in 1703 there came into existence the Methuen Treaty between Great Britain and Portugal. Under this " preferential" treaty Portuguese wines came to Britain on considerably better terms than French wines, and the woollen manufactures of Britain were admitted into Portugal, the prohibition being taken off.

The result of this treaty was remarkably beneficial both to the wollen and cotton industries in England.As Portugal under this arrangement now sold large quantities of port and other wines to England, she took large supplies of cloth in return. Trade between the two countries grew and developed, and Portugal, importing many other commodities in course of time from England, paid for them in bullion estimated at $£ 50,000$ a week. ${ }^{1}$ This bullion-obtained by the Portuguese from America-was in turn used by the British in their East Indian trade where bullion was indispensable. From India they obtained, in addition to spices and fans, large quantities of cheap and beautiful silk and cotton fabrics. These became so popular as to threaten the Lancashire cotton industry, and in 1700 an " Act for the more effectually imploying the poor by encouraging the manufactures of this Kingdom" "was passed by the

${ }^{1}$ Cunningham, Industrial Revolution, p. 461.

${ }^{2}$ Ibid., p. 465. 
British Parliament under which Indian fabrics might be warehoused for re-exportation, but could not be sold within the country. The effect of this was that the Lancashire cotton industry had its own home market protected in England, and the East India merchants were at the same time able to get their profit by selling the Indian fabrics on the Continent of Europe. Europe for a time bought cheap fabrics. England established a great cotton manufacturing industry. List's comment on these transactions is interesting. He says:-

"Was England a fool in so acting? Most assuredly, according to the theories of Adam Smith and J. B. Say, the Theory of Values. For, according to them, England should have bought what she required where she could buy them cheapest and best; it was an act of folly to manufacture for herself goods at a greater cost than she could buy them at elsewhere, and at the same time give away that advantage to the Continent. The case is quite the contrary, according to our theory, which we term the Theory of the Powers of Production, and which the English Ministry, without having examined the foundation on which it rests, yet practically adopted when enforcing their maxim and importing produce and exporting fabrics. The English Ministers cared not for the acquisition of low-priced and perishable articles of manufacture, but for that of a more costly but enduring manufacturing power.

"They have attained their object in a brilliant degree. At this day England produces seventy million pounds' worth of cotton and silk goods, and supplies all Europe, the entire world, India itself included, with British manufactures. Hor home production exceeds by fifty or a hundred times the value of her former trade in Indian manufactured goods. What would it have profited her 
had she been buying for a century the cheap goods of Indian manufacture? And what have they gained who purchased those goods so cheaply of her? The English have gained power, incalculable power, while the others have gained the reverse of power." 1

The shipping of England was developed under a series of Navigation Laws thoroughly protective in character. And although Adam Smith, in order to support his Free Trade doctrine at all hazards, and under all circumstances, makes a distinction between the political and economic effects of these laws, it is impossible to concede that even on purely economic grounds in the long run they were not advantageous.

List sums up the position as follows:-

"The truth of the matter is this. Restrictions on navigation are governed by the same law as restrictions upon any other kind of trade. Freedom of navigation and the carrying trade conducted by foreigners are serviceable and welcome to communities in the early stages of their civilisation, so long as their agriculture and manufactures still remain undeveloped. Owing to want of capital and of experienced seamen, they are willing to abandon navigation and foreign trade to other nations. Later on, however, when they have developed their producing power to a certain point and acquired skill in shipbuilding and navigation, then they will desire to extend their foreign trade, to carry it on in their own ships, and become a naval power themselves. Gradually their own mercantile marine grows to such a degree that they feel themselves in a position to exclude the foreigner and to conduct their trade to the most distant places by means of their own vessels. Then the time has come when, by means of restrictions on navi-

${ }^{1}$ List, National System of Political Economy. 
gation, a nation can successfully exclude the more wealthy, more experienced and more powerful foreigner from participation in the profits of that business. When the highest degree of progress in navigation and maritime power has been reached a new era will set in, no doubt; and such was that stage of advancement which Dr. Priestley had in his mind when he wrote ${ }^{1}$ 'that the time may come when it may be as politic to repeal this Act as it was to make it '."

That time doubtless did come, and British shipping is free. But it is significant that only recently we have passed a Merchant Shipping Act to remedy a state of things in which that freedom had been carried so far as to allow foreign shipowners a freedom from restrictions with regard to British trade which we did not allow even to our own shipowners.

In the same way our numerous manufacturing industries have run for a long period without the "props" of Protection which were so lavishly bestowed upon them in their infancy. That some of the fostering measures of Protection were crude, clumsy, and unscientific no modern student of economics will deny. But that a system of absolute Free Trade would have served those infant industries as well it seems impossible in face of their history to believe, except on the one paramount condition, that of universal Free Trade.

If, for instance, the doctrine of Lord Avebury with regard to America ${ }^{2}$ be applied to England, would it not compel us to argue that the English should have continued a race of wool growers and allowed Flanders to retain for ever the position of cloth manufacturers? A 289.

"Priestley, Lectures on History and General Policy, Pt. ii., p.

2 Vide above, p. 56. 
position we were only finally able to share with Flander's by taking the most stringent measures of Protection in order to get our industry started and established.

In the same way, would our cotton industries have developed as they have done if our ancestors had been content to import the fabrics of India? And if these great industries had not been developed, what were to be the alternatives? Were the breeding of hogs and sheep to continue indefinitely our chief occupations?

But let us pursue the analysis of this question a little further.

If it be once conceded, and the concession is freely made by John Stuart Mill, ${ }^{1}$ that it may be expedient to protect an infant industry, what valid objection can be urged against the possible expediency of offering some measure of protection to an injured industry?

In the language of that metaphor which economists have chosen to apply to this subject, if nursing be necessary to the infant is it not equally so for the injured?

If, in other words, a matured industry is subjected to precisely those same unfair conditions of competition which render the life of an infant industry so precarious as to demand Protection, why should not some measure of that same Protection be expedient for the matured industry?

As the preservation of productive power in a State should be one of the first objects of applied Political Economy, there can be no question that under certain conditions the matured industry should be so assisted. All civilised nations except Great Britain are to-day convinced of this fact.

${ }^{1}$ Mill, vol. ii., p. 487. 


\section{CHAPTER VII.}

\section{GREAT BRITAIN'S FREE TRADE ERA.}

Free Trade policy of England defined-Its expediency-Cobden and Bright on the Corn Laws-First half of the Free Trade era-Foreign rivals in the forties-Second half of Free Trade era-Industrial position-Injured industries-Motor industry -Woollen manufactures_Shipbuilding-Cotton-The wealth of England not necessarily an index to success of manufactures -The attractions of England as a place of residence-Great value of British Home Market-British wealth and British industry are things apart-Investment abroad-The mazy abstractions of the President of the Board of Trade-Analysis of a foreign investment-Unsatisfactory nature of our trade with Germany-The calamity of unemployment-Producer must be considered with the consumer-Protected labour and free imports-Objections to a tariff-Bismarck on the British Free Trade era.

IN preceding chapters I have recorded and briefly reviewed the testimony with regard to the duration, nature, and effects of certain eras of Free Trade, or eras in which the fiscal policy showed a tendency towards Free Trade, in the United States and Germany. We have seen that in both these countries, after trials of certain periods of Free Trade, the protective system was reverted to, until to-day carefully calculated scientific Protection, Protection especially directed to employing labour at home to the fullest extent, is the avowed policy and practice of both these countries. 
It is now necessary to consider and, as far as possible, analyse the remarkable Free Trade, or more accurately free import, era which has existed in England since the forties of the last century down to the present day. Without stopping to discuss the amount of wisdom there may be in the proverb "Vox Populi, vox Dei," it is undoubtedly a significant fact, and one which no impartial student of this problem can afford to ignore, that during that period, at least to within the last few years, the free import system has been approved by the majority of the people of these islands. This policy, within that period, has guided the legislation and administration of British Govermments of both political parties. That it has from time to time been challenged, more especially in the fair trade agitation of the eighties, is true, but that in the main it has received the assent and support of the majority of Englishmen cannot be denied.

It is well that we should here define more precisely the so-called Free Trade policy of England. The principles recognised are;

That there shall be no duties of a protective character whatever, that is, no duties on imported goods which are also produced at home. But on the other hand, duties must be of a purely revenue-producing character, revenue taxes, as they are called, on certain articles not produced at home, such as tea, coffee, sugar and tobacco, and on which therefore any duties levied cannot have a protective effect. Further, there are also customs duties on certain foreign goods, such as spirits, equivalent in amount to the excise levied on these articles when produced at home.

That these principles, although avowed with great fervour by their advocates, have not always been rigidly adhered to of recent years we have already seen in dis- 
cussing the doctrines and practice of the laissez-faire school. Still, broadly spealing, it may be said that England is the one great civilised country in modern history in which the policy of free imports has been regarded over a long period of years as the most expedient and most successful policy to adopt.

The questions then to which we have to address ourselves are :-

On what grounds is the expediency of this policy based?

Is the policy, even if expedient for a time in the past, necessarily expedient to-day?

At the outset it must be conceded that the Free Trade doctrines propounded by Turgot and Say, and stated with such conspicuous ability and lucidity by Adam Smith, impressed themselves in a remarkable manner upon many Englishmen early in the first haif of the nineteenth century. So impressed was Buckle with the intellect of Adam Smith that he writes of him as by far " the greatest thinker Scotland has produced ". And although to-day we may seriously question the cardinal doctrine on which Adam Smith based his system, namely, that the sum of individual actions, unrestrained and unregulated by Government interference, short of actual crime, will necessarily best serve the interests of the whole community, it is certain that this view came to be largely adopted and was freely expounded by the Manchester school of politicians.

Moreover, not only was Adam Smith a great force in himself, but he was succeeded, and his doctrines still further extended and modified, by such writers as Ricardo and Mill. Some of the conclusions, hypotheses, and fallacies of this school of writers, as well as some of their predictions, were dealt with in the first chapter, and it is

${ }^{1}$ Buckle, History of Civilisation in England, vol. ii., p. 457. 
not necessary to discuss them further here. At the same time, in considering the causes of the British free imports era, the great influence of these writers, which was felt not only in England but throughout Europe and America, must be rated high. And although Free Trade as conceived, expounded and put in practice by the laissez-faire politicians may not have been the idea] policy for England, its adoption at any rate was followed by a period of great prosperity.

The Corn Laws, which were started in 1815-to encourage agriculture - were by Governments, chiefly under the influence of country squires and the farming interest, carried to an unfair extent. Thus by the Corn Law of 1828 it was provided that when the price of wheat was as low as 66s. a quarter the duty should be 20s. 8d. a quarter. This may have been Protection, but it was not reasonable scientific Protection, it was arranged in the interests of one class rather than in those of the community generally. And it was denounced as inexpedient almost as strongly by List-an avowedly protectionist writer-as by the Corn Law agitators in England.

Where Protection is used at all it must be used to promote a symmetrical national development such as is arrived at to-day both by the United States and Germany. In the instance of the Corn Laws, the manufacturing and working-classes believed themselves, not without reason, to be unduly sacrificed in the interests of agriculture. Cobden and Bright and the Anti-Corn Law agitators succeeded in getting these Corn Laws abolished, and one of the weapons they used was Adam Smith's doctrine of Free Trade. At the same time it is a remarkable fact that although the exorbitant duties under the Corn Laws furnished politicians with magnificent material for 
perorations, and were indefensible, as they stood, on any fair basis of taxation, it was many years after their abolition before the price of wheat in England was materially affected. To a certain extent, and for a time, Cobden was right, the freight charges of his day and for many years afterwards did afford the farmers of England a means of Protection, or, as Cobden preferred to describe it, a "Natural Protection". Other causes also, such as the Crimean War and the American War, tended to keep foreign wheat supplies down. But art overcame nature. Freights became a dwindling quantity, enormous fresh wheat areas were opened in America, and from the late seventies onwards the real drop in the price of wheat occurred.

The policy of Free Trade-beginning with the Repeal Act of 1846 abolishing the corn duties-was extended at the same time, and at intervals, for several years subsequently, to many other articles of commerce until the year 1860, which practically brought the process of abolishing duties to an end. Judged by any test that can fairly be applied, the progress for twenty-five years after the new free import fiscal policy was introduced was rapid and substantial, especially when compared with the progress for twenty-five years previously. Thus, taking the test most frequently applied, that of exports, although as already stated there are many objections to relying too exclusively on this test, we find that in $1820^{1}$ the value of exports was estimated at $£ 21$ s. 9 d. per head, that twenty years later, during the Corn Law era in 1840 , they only stood at $£ 118 \mathrm{~s} .9 \mathrm{~d}$. a head, but that in 1860 they had risen to $£ 414$ s. 7 d.; 1870, $£ 6$ 9s. 6d.; and in 1872, a phenomenal year, they were as high as $\mathfrak{f} 8$ 1s. per head.

${ }^{1}$ Figures prior to 1854 are approximate only. 
Some writers to-day very properly contend that this progress was due to other causes than free trade, and although the relative value of different factors in the advance must always be difficult to estimate, there is no doubt that many other causes did operate favourably on the trade of Great Britain. Among these were the discovery of the Californian and Australian goldfields and the continuous advance in all sorts of improved machinery-more particularly in the textile trades. But nevertheless, allowing for all these factors, it appears difficult to avoid the conclusion that the policy of free imports during the first half of the period under consideration-that is from the fifties to the eighties-did contribute to the commercial and industrial prosperity of that time. In any case the Free Trade policy during that time was undoubtedly better for England than the fiscal policy-most particularly as expressed by the Corn Laws-which had immediately preceded it.

It need hardly be pointed out that it is possible to hold this view without necessarily believing that the extreme form of free import policy adopted was the best and most expedient that might have been adopted. Time does appear to have disclosed-more particularly in quite recent years-certain directions in which it has told adversely against the true interest of England, and tended to a one-sided development which might have been avoided with economic and great national advan. tage. But reserving this point for further consideration, it will be interesting to consider certain further reasons for the industrial prosperity of this period.

In the forties the rivalry of foreign countries in manufactures was comparatively slight. As evidence of this it is only necessary to refer once more to the 
estimate of England's position made by List in his day (vide above, p. 76). The danger of competition with foreign manufactured goods in the home market hardly existed.

Further, if Cobden was successful in establishing his doctrines and policy at home, he was not entirely without success abroad. The doctrines of Free Trade were discussed in every country, and the tariff legislation of Germany and of the United States during this period towards a relaxation of Protection has already been referred to. England, therefore, down to the seventies was not exposed to the high foreign tariffs she has since had to meet. Had this passing disposition on the part of foreign countries only become a permanent one, and Free Trade been generally and permanently adopted, as Cobden and Mill anticipated would be the case, the fair trade and the most recent tariff-reform controversies in England would never have arisen, and there is little doubt that in a Free Trade world England would have maintained her industrial and commercial supremacy unchallenged. But foreign countries found Free Trade too costly from a national point of view, and soon reverted once more to Protection. England thus had to eliminate the hope and inducement held out by Cobden of a Free Trade world, and decide whether or no free imports was still her best policy even in a protectionist world. Hitherto she has decided in the aftirmative. But if it be conceded that on the whole British trade, industry, and general material welfare were benefited by our present fiscal system down to the time of the seventies or eighties of last century, it by no means follows that the same is true of the last twenty years, much less of to-day. Nor does it follow that there were not grave defects in that policy which might have 
been avoided with considerable national and even economic advantage.

The industrial, agricultural, and commercial history of the second half of the British Free Trade era now calls for some consideration. It by no means presents the same relative or actual advance as was to be observed in the first half. Broadly speaking, what has happened has been a continuous and large rise in our imports of manufactured goods; stagnation or an actual fall in our exports of manufactured goods through the greater portion of this period, but slightly compensated for by a rise in the last few years.

The figures, illustrating this, compiled from the Board of Trade returns, are set forth in Mr. Holt Schooling's British Trade Year Book, from which a few figures may be quoted.

Thus, taking the decade 1880-89 our imports of manufactured goods stood at a yearly average of 79 millions, with every succeeding decade the average rose until, in 1898-1907, it stood at 134 mllions.

On the other hand, our exports of manufactured goods stood at 201 millions in the decade 1880-89 and remained at about that level, sometimes slightly above and sometimes below, down to the decade 1893-1902. They then began to rise until, in the decade 1898-1907, they stood at 242 millions-a more satisfactory position if there were not already signs of our again receding from it.

The position indicated by these statistics is that of the home market being increasingly invaded by foreign manufacturing competition, and a foreign export trade not even increasing to a sufficient extent to compensate for that invasion-to say nothing of the further increase required by an increasing population. The results to 
be anticipated from such a position are that certain industries will be injured or even killed by competition, that capital will be lost or withdrawn from such industries, and that workmen will be thrown out of employment. And unfortunately these results have occurred. Reference has already been made to the continuous and increasing flow of capital from this country for investment abroad (see above, p. 35). A portion of this increased investment abroad is undoubtedly capital withdrawn from certain declining industries in England.

The Tariff Reform League and Tariff Reform Commission have collected, compiled, and published statistics in regard to a number of injured British industries disclosing the nature of the mischief which is going on.

To review this evidence, or in any adequate way to attempt to deal with the present position of the whole of the industries of England, would be beyond the scope of this work. But a few instances may be briefly referred to as illustrating the disadvantages which manufacturers and workmen have to contend against under existing fiscal arrangements, whereby the foreign manufacturer has his home market secured to him, and the British manufacturer has to face the competition of the world.

Perhaps the most modern of all the greater industries, involving a very large amount of highly paid labour, and therefore of special value from a national point of view, is the motor industry. The introduction of the motor car has been attended with results of an economic character in more directions than one.

In the first place it has struck severe blows at the carriage-builder, the harness-maker, and the farmer. It is beginning to tell on the returns of the railways. 
In this way it has dislodged a certain amount of both capital and labour, and as already pointed out, although capital may find investment elsewhere, it is not so simple a matter, as Professor Marshall and other laissez-faire writers suggest, for labour to do so.

Moreover, the motor consumes petrol and india-rubber -both foreign imports-and not oats, hay or straw, as the farmer knows to his cost. Still such a change as this is inevitable from time to time in the nature of things, and will come under any fiscal system in the world. The real question at issue is whether there is anything in the fiscal system which prevents this country from obtaining the only compensation which such a change has to offer, namely, that obtainable by both capital and labour from the development of the competing industry itself.

The manufacture of a motor car requires a large amount of skilled labour. The raw material used is about a tenth of the cost of the car when sold, and nearly the whole of the balance is paid in wages. Motors have been freely manufactured in many countries -especially France, Germany and the United Statesand in each of these countries the manufacturer has started on his enterprise with the assurance that the home market was largely secured to him by the protective tariff. He has thus been able to employ large capital with confidence, to standardise all important parts of the machine, to manufacture on a large scale and so reduce the costs of production to a minimum.

By this means he can arrange to export at a relatively low price, and as England is the one large market to which he can obtain free access, it is here chiefly that his exports have been sent.

The English manufacturers, on the other hand, have 
found the greatest difficulty in building up a new industry - it might even be called an infant industryagainst such overwhelning competition. Had their market been even partially secured to them by the most moderate tariff, they could have entered on the new industry with some confidence and on a sufficiently large scale; but as it is, the history of the motor industry in England has been one of disappointment and financial disaster.

Free importers may of course urge that motors have by this system been obtainable more cheaply here than elsewhere, but it behoves us to consider at what cost to the many this cheapness for the few who buy motor cars has been obtained. In 1907 the money spent on imported motor cars, and parts thereof, amounted to $£ 4,552,786$, of which at least four-fifths went to foreign workmen. ${ }^{1}$ And this, it must be borne in mind, is an industry which has to a large extent displaced others already referred to of native origin, and has driven British workmen in certain other trades out of work.

As against this large import the export of motor cars was below a million pounds in value.

Here, then, is a clear instance of labour being displaced from old industries in England, and being replaced-if it inay be said to be replaced at all-by labour abroad. What became of the labour thrown out of work in England may, we fear, be more accurately gathered from the statistics of unemployment than from Professor Marshall's doctrinaire utterance on the subject.2

But a still more striking and significant instance of the peculiarities of our present fiscal position is disclosed by one of those textile industries which for so many years was our greatest industry. The woollen manufacture,

${ }^{1}$ Statistical Abstract, 1908 [Cd. 4258]. $\quad{ }^{2}$ Vide above, p. 38. 
to which considerable reference was made in the preceding chapter, was described in the seventeenth century as "the flower, and strength, and revenue, and blood of England". And as List wrote: "It was round the woollen industry of England that all other branches of manufacture grew up as round a common parent stem; and it thus constitutes the foundation of England's greatness in industry, commerce and naval power".

This industry-so firmly established and deeply rooted in the age of Protection-forms an interesting object for study during the era of free imports. In 1895 there were employed in the woollen, worsted and shoddy trades of England and Wales 282,401 persons; in 1904 this number had fallen to $261,801 .^{1}$ Continual improvements in machinery no doubt partly accounted for this, but there is another reason which is far from satisfactory. Exports of finished goods to foreign countries have diminished since the quinquennial period 1885-89. On the other hand there has grown up a great export trade in " noils" and "tops," the technical terms for scoured and combed wool. The processes of scouring and combing wool call for the lowest grades of labour in the industry, and this semi-raw material purchased here is sent abroad and made up abroad into finished articles.

In 1906 the imports from foreign countries of finished goods were over ten millions in value, while those sent abroad to foreign countries only amounted to a little over thirteen millions. It is true that while the export to foreign countries has shrunk, that to the colonies has increased, but only just enough down to 1906 to balance the loss in foreign exports.

So that over a period of twenty years, in spite of the Statistical Abstract, 1908 [Cd. 4258]. 
great increase in population, this industry-once the "flower and strength and revenue" of England-has been largely ousted from the home market, and has only been prevented from actually going back in its export trade by the growing colonial market. It is yearly becoming more apparent that it is impossible to combine a system of the most highly protected labour in Europe with a system of absolutely free imports without seriously injuring some of our most important industries.

The change which in the last twenty-five years has come over British agriculture has already been referred to.

On the other hand there doubtless are some industries which appear to have advanced, or at least to be holding their own. Those most frequently quoted by the advocates of Free Imports are shipbuilding and the cotton trade.

With regard to shipbuilding one important fact is continually overlooked. The spirit and practice of the old Navigation Laws-so extolled by Adam Smith and at the same time so thoroughly protectionist in characterhave never been entirely departed from. It is still a stipulation in all admiralty contracts for ships that British materials only must be used in building them. When the enormous quantity of material and construction used in building our battle-ships is borne in mind, it will be recognised that this is really a measure of Protection which contributes, materially, to the security and stability of the shipbuilding industry as a whole and of the subsidiary industries which feed it.

The cotton industry continues large, and as a whole, owing to the increasing exports to our colonies, still appears to be growing, but even here there are certain facts which give rise to a doubt as to whether under 
existing conditions we may not rather anticipate a diminution than an increase in the future. America now consumes more raw cotton than we do, and Germany is rapidly gaining on us. Moreover, both countries are increasing their exports of cotton goods more rapidly than we are. The number of persons employed in the cotton trade in the United Kingdom was smaller in 1901 than it was ten years previously.

But if shipbuilding and the cotton trade may still be claimed as flourishing industries, there are unfortunately a number of others which are either stationary or declining, or at least were so over a period of twenty years, until the boom of 1907 gave them a temporary revival from which they are already once more receding. Viewed, therefore, as a whole it cannot fairly be contended that the industrial and trade results obtained during the second half of the Free Trade era in Great Britain, especially when compared with the results obtained by our manufacturing rivals in that same period, can in any way be regarded as evidence of the value of the existing fiscal system to that industry and trade.

Moreover, what is more unsatisfactory even than the statistics and evidence we have been considering, is the large amount of unemployment and emigration as evidenced by the official returns. ${ }^{1}$ For two years past the amount of unemployment in England has exceeded considerably that in Germany.

There is one argument frequently used by free importers in favour of the present system which appears to give rise to great misapprehension and which requires careful examination.

Apologists of the free import system continually refer to the wealth of England,-as evidenced in various

${ }^{1}$ For statistics of emigration see above, p. 82. 
ways, the income tax returus, money invested in foreign securities, the large number of the wealthy leisured classes, and numerous other facts, all of which they regard as satisfactory and all of which they attribute to Free Trade. That England per head of her population is still the richest country in the world is probably true; that she gained much of that wealth during the Free Trade era, and even for the first half of that era, partly owing to Free Trade, may also be admitted. But that she has gained her wealth, to anything like the same relative extent, from her industries under Free Trade in the second portion of this era is certainly not the case.

England enjoys one great advantage, and has enjoyed it increasingly, during the last quarter of a century. She offers to the wealthy, leisured classes of the AngloSaxon race many attractions as a place of residence. Wealthy Americans as well as wealthy colonists still find England the most agreeable place to live in-at any rate for a considerable portion of the year. The art of healthy, enjoyable country life is better understood and practised by the wealthy classes in England than anywhere else in the world, and even to the poorer classes a greater measure of this enjoyment is extended than in other countries.

The field sports and games of England are often made a subject of reproach by apologists of the laissezfaire system in industry and trade, who, rather than admit any possibility of defect in our present fiscal system, are apparently ready to attribute the stagnation in industry and the unemployment of British workmen to anything and everything else, from the consumption of alcohol or tea, to the hunting field or the village cricket club. But as a matter of fact, the pluck, the 
enterprise and the pioneering instinct which have led the British race to overrun and colonise successfully in every corner of the globe were largely trained, reared, and nourished in the hunting and playing fields of England.

Open-air games are an evidence and source of virility, not a sign of decadence or sloth. And whatever mistakes we have made we still do not produce to any great extent among our upper and middle classes either the neurotic type of American, or the myopia so frequently seen among modern Germans. England's public schools and universities, in which the healthy tradition of physical training is so well combined with mental training, draw many colonists and Anglo-Saxons from all parts of the world to England.

But most potent of all advantages to the capitalist is probably the fact that London still remains the great exchange of the world. In no market is so much capital invested abroad, and in no market are there as many facilities for this form of investment. These reasons all combine to make England the home of a very large class of wealthy people who spend money freely in the country and whose residence in the country is no doubt an advantage in many ways, but whose financial interests are international rather than national, and a greater portion of whose wealth is drawn from investments abroad.

The buying power of this portion of the community is a very important factor in the British home market, for all sorts of finished commodities, but so long as that market is equally accessible to all competitors it is little more a source of advantage to the British than to foreign manufacturers and workmen. In fact British industry and British wealth, under the existing system, are things 
apart. There is no necessary or constant relationship between the two. British wealth may actually go on increasing when British industry is waning. Thus capital may be withdrawn from British industry and invested more profitably abroad. As Goldsmith long ago realised, you may have a condition of things in which

Wealth accumulates, and men decay.

To all appearances we seem to have to some extent such a condition of things now, and the cause is neither the village ale-house nor drinking tea--nor are the remedies total abstinence, the abolition of games, or Socialism.

Recent debates in the House of Commons have disclosed an amount of doctrinaire bigotry on this subject which may well astonish the ordinary reader. The confusion of mind which exists on the subject of wealth, and the satisfaction which the British producer ought to derive from the reflection that so long as Englishmen are increasingly investing abroad all must be well, would be ludicrous if it were not so disastrous.

As an illustration of this delusion, and the paralysing complacency which it appears to confer even on the minds of those who are in a measure responsible for the country's position in trade, I cannot do better than quote from the speech made in the House of Commons on 19th February, 1909, by the President of the Board of Trade, who said:-

"I recognise that the rate of investment abroad is increasing at the present time. I assert also that investment abroad is beneficial. It is a very good thing for British capital that it should be able to secure for itself a share in the new wealth and the new opportunities and the great resources of the whole world. Such 
a system of investment develops our trade connections with many countries. It develops the British Empire for which hon. gentlemen opposite are so ready to speak in terms of umrestrained panegyric and enthusiasm. It can only leave this country, as the Prime Minister told us, in the form of exports, the produce of British labour, and while it goes in these exports it returns a handsome and profitable return not only in the interest but very often in a marked increase of the capital sum to those who have made the investments." 1

To the first portion of this statement no exception need be taken. Lucrative foreign investment is a perfectly legitimate and excellent thing for the investor, and indirectly, in so far as it gives those investors dividends to be expended in the country of their residence, not a bad thing for England. But the whole question at issue is, does this large and increasing foreign investment necessarily afford any guarantee whatever as to the satisfactory position of British producers? As a matter of fact the two things stand apart. The capital going abroad may be and indeed is largely, if not chiefly, the re-investment of profits made abroad, it is also at the present time largely money withdrawn from declining British industries, and from the sale of British securities which are shrinking in value. In what way then can this tide of capital flowing out of the country be regarded as an index of the prosperity of British producers?

Let us take an actual concrete case that recently came under my notice. A British investor having a large sum of money invested in the shares of a well-known British motor manufacturing company became dismayed at the continual decline of the industry, sold his shares and

${ }^{1}$ Mr. Winston Churchill, Times, 20th Feb., 1909. 
invested the proceeds in United States Steel Preferred shares which yield him a good cumulative dividend. Meanwhile the motor company, having exhausted its working capital, endeavoured to raise more by issuing fresh shares. But the continuous decline in the price of the shares rendered the issue a failure. The company had to curtail its operations, and the shareholders incurred great losses. In the case referred to the shareholder withdrew such money as he could save from a declining British industry to invest it in a thriving American one, which behind the walls of a tariff has grown to such dimensions as to be now capable of profitably invading the British market.

In what way do British producers profit by this "foreign investment"?

It is clear those engaged in the motor industry do not do so. They, under the stress of foreign competition and the consequent withdrawal of British capital, have had to close a large portion of their works and dismiss their workmen. No. The advantage to the British producer is of a much more subtle character than that. It is only to be discovered by recourse to a theory based on mazy abstractions, which apparently are ample for the purposes of a President of the Board of Trade, but are entirely inadequate for the requirements of trade itself.

What is this theory? It is that capital "can only leave this country in the form of exports, the produce of British labour".

That a statement of this sort might emanate from the somewhat arid discourses of certain laissez-faire academic schoolmen, with no practical knowledge of business, and a blind devotion to those assumptions which Jevons so roundly denounced, is conceivable, but that they 
should fall from the lips of a President of the Board of Trade who from his official position must be assumed to have some knowledge of the department over which he presides is a remarkable piece of evidence of how far the influence of the popular fallacy with regard to imports being paid for by exports extends. The nature of this fallacy was discussed in Chapter III., and the frequency with which it gives rise to the suggestio falsi referred to. It would be difficult to find a more striking example of the erroneous conclusion to which this fallacy continually leads than that furnished by the President of the Board of Trade. The statement is of sufficient importance to lend some interest to its detailed analysis which we may proceed to consider.

In the first place to say that "capital can only leave this country in the form of exports, the produce of British labour," is on the face of it a mis-statement of actual fact. Let us follow what occurs when a purchase of say American securities is made. The shares are sent to the purchaser. The payment made for them is sent in the form of a bill of exchange, a cheque, or a credit transfer to America, where it passes to the credit of the seller of the securities. It remains, as a debit against this country, an exchange value which will be disposed of as convenience and the position of trade requires, thus it may be liquidated forthwith in bullion, be used in course of exchange to defray expenses of American tourists, or even go in part payment of a deer forest in Scotland, or a residence in England. It may be used to pay for British services in various forms, and it may be used to pay for manufactured goods if such goods happen to have been purchased, but it does not determine such purchase. In what form, other than an exchange value, it ultimately finds its material equi- 
valent either within, or as an export from, this country, is dependent on a dozen other factors besides that of British industry. And to seriously maintain that it can only be exchanged for manufactured goods, and that it necessarily creates the demand for these goods, is entirely untenable.

No doubt one of the theories which underlies this argument is the "abstraction" that an exchange value sent to the States increases the buying power of the States, and that this buying power will directly or indirectly, probably through a third country, eventually be exercised by obtaining some material equivalent from Great Britain for that exchange value. But even granting the truth of this proposition, the supply of that material equivalent may take, as already pointed out, many forms alternative to manufactured goods. Thus on examination it will be seen that the utterance of the President of the Board of Trade is fallacious to the core. It might well be regarded as the official death knell to the system of free import finance.

The truth is, the success of the English producing industries turns on a good deal more than the mere buying power of foreign countries. That any increased buying power in a foreign country is going to increase that country's purchase of our manufactured goods entirely depends on the resources that country has for manufacturing similar goods, the amount of tariffs such a country places upon our goods, and the extent to which we can hope to trade in the face of those tarifts.

Take the nature of our trade with Germany to-day. In the year 1907 our imports from Germany of articles wholly or mainly manufactured amounted to 38.6 millions. Our exports of the same class of goods to Germany only amounted to $29 \cdot 7$ millions. The balance of trade 
in manufactured goods is thus entirely in favour of Germany. We who, with our open competitive market, are more dependent on our export trade than any of our protectionist rivals, send less manufactured goods to Germany than she does to us. While, on the other hand, Germany gets, in addition to coal, other raw or semi-raw material from us in increasing quantities, which, when duly made up into finished manufactured material, the product of German labour, comes back to compete with the products of British labour.

Thus it will be seen that the mere wealth of England, in the sense of mere buying power, whether we have regard to the proportion spent on living and luxury in this country, or sent abroad for investment, does not, under the free import system, necessarily afford any great support to British manufactures and workmen. It doubtless does an excellent turn to the merchant. But the British producer must take his chance of custom from this wealthy buyer in free competition with all the rest of the world. At the same time it must not be overlooked that the very presence of a comparatively large wealthy class does confer an exceptional value in buying power upon the British home market, a value which would speedily be felt by the British producer as soon as he had the advantage of a moderate tariff over his foreign rivals.

The foregoing considerations do appear to establish the fact, that the wealth of a certain class or indeed the total wealth of England estimated by the sum of exchange values, or in other words purchasing power, must be regarded, as long as the free import system obtains, as something distinct from British industry. British industry may be stationary or even declining and yet the actual wealth of England increasing. It is therefore a 
source of perpetual and most unfortunate error to confuse the two. And to refer complacently to the extent of the latter as necessarily indicating a flourishing condition of the former is entirely misleading.

Nor from a national point of view can it for one moment be conceded that an increase in wealth is an adequate compensation for a declining or even a stationary condition of industry. The success of industry is the welfare of millions. The accumulation of wealth is the privilege of the few. No nation, much less a nation like the British, of only a comparatively moderate population, at the heart of a great empire, can afford to see workmen in great numbers, either enduring the misery of unemployment or quitting her shores for ever. Continuous unemployment is a calamity, first and foremost of all, on those grounds of humanity which England has so frequently made not merely the subject of her impassioned panegyric, but her substantial sacrifice. And it is further a calamity on every ground of national wellbeing.

The time has come when the producer must be considered at least equally with the consumer. The policy of laissez faire abandoned the producer utterly, but abandoned him fortunately at a time in England when he had practically no competitors and was well able to take care of himself. But to-day all is changed. Trades unionism has protected and conditioned labour. Trades unionism is as far removed from the traditions of laissez faire as the most extreme protection of Germany or America. And yet trades unionism cannot produce a demand for labour. It may even have been unconsciously instrumental in diminishing the demand for labour. Thus to protect and condition labour, but to admit free the products of foreign unconditioned sweated labour, is 
to injure certain branches of British industry, and to throw British workmen ont of work.

A tariff, however moderate, would, it is argued, whatever effect it might have on productive industries and those directly interested in them, increase the burdens of those not dependent on them.

In the first place, those in no way dependent on British industry are comparatively few, and would chiefly be found among the wealthier classes. Moreover, actual necessities need not by any scientific discriminating tariff as a whole be made dearer.

But even if certain articles cost a little more, the tariff would be such an addition to the revenue as to lighten other taxes which at present are growing to alarming proportions, and by this means largely compensate for such additional cost. And if some small sacrifice were called for in certain few cases would it not be worth making? To eliminate unfair competition, to give more security to capital invested in British industries, to increase the demand for labour-all of which results might reasonably be expected to ensue in time as a result of a moderate tariff-would, from a national point of view, be of immense advantage.

The productive powers of England cannot be sacrificed indefinitely, no matter how desirable for the wealthier classes the purchase of luxuries at the cheapest possible rate may be. And unless the industrial productive power of England develops and grows coordinately and interwoven with the growth of our colonies, the Imperial fabric will tend to disintegrate.

Finally the evidence we have adduced and considered does seem to point to the conclusion that Free Trade is 
in its essence a cosmopolitan ideal; that when other nations declined to adopt it England nevertheless did for a time practise her system of free imports without detriment, possibly with advantage, to her great industries. But only exceptional advantages, only a unique position could render such a policy expedient in the midst of a protectionist world. For a time, possibly down to about the late seventies, England had these advantages. From that time onward they gradually fell away. The Protection of both the United States and Germany became scientific and intensely national ; freights continued to drop, removing what vestige of natural Protection England had left to her. Factory legislation and trades unionism all protected and conditioned labour, without in any way creating more demand for it or without being accompanied by any legislation to protect it from the competition of the products of foreign sweated labour.

The results on the home market and our export trade, together with the rapid progress of our chief rivals, have already been dealt with. The inference which as a whole we are compelled to draw does appear to be that whether or no a change in our fiscal system would, as the writer believes, have been wise and expedient in the eighties, the time has at least come to-day when once more tariff reform-this time on moderate protective and preferential lines-has become as expedient and as imperative a change as tariff reform in another direction was in the time of Cobden.

England like other countries has had her Free Trade era. With us it has lasted longer than with any other country in modern times. But as Bismarck long ago emphatically predicted, even with "burly, full-blooded England," it cannot last for ever. 


\section{CHAPTER VIII. \\ THE COLONIES AND INDIA.}

The alternatives-The fate of small States-The great federal instrument-Preference-Free Trade and disintegration-Universal peace-The bygone forebodings of Lord MorleyFurther miscalculations-March of events forward to Federation, not backward to separation-A Customs Union-Though colonial fiscal systems vary, all have one feature in common, the taxation of imports-Three sets of proposals on Preference -The fiscal system of India-British objections to Preference considered-Free Food fallacy-England an obstacle to freer trade-Most-favoured Nation treatment-Füchs on the Trade Policy of Great Britain-Closer union essential to the Empire - Has Free Trade been carried too far ?--Change must come "soon, or for ever too late"-Füchs' warning to GermanyThe advantages of Preference-The goal a federated world State.

IN turning our attention from Great Britain herself to the British Empire as a whole, there are certain points of dissimilarity to be borne in mind. Thus, whereas the kingdom of Great Britain is one of the oldest in Europe, the British Empire of to-day is young. It is younger for the most part than the United States, but still considerably older than Germany, which is the most modern and at the same time the most highly organised political federation in existence.

England's maritime supremacy - the foundations of which were laid in the time of the Tudors-and the enterprise and pioneering instincts of her sons, have 120 
been chiefly instrumental in acquiring colonies. $\mathrm{Her}$ colonial history has passed through two stages, has been the record of the acquisition of two Empires. The first of these-the American Colonies, now the United States-has been lost to us. The fate of the second British Empire still remains to be decided, but in the event of its following that of the first it is clear that as the surface of the earth is now allotted among different Powers there can never be a third.

From the day, therefore, that we part with our present colonies, the British will come under the category of those dead empires for which there can be no further resurrection. Under these conditions England would become such another small State as Norway, or, to take the instance of a wealthier small people, Belgium.

It is well sometimes to put before ourselves what has been and what may be. And before being dismayed at the difficulties in the process of integration, in the path of a closer federal union, and the construction of a more maturely developed federal organism, we must at least not shrink from a careful estimate and realisation of what the alternative, the process of disintegration, would mean. To suppose that a severance from our colonies, a retirement from our present position into that of a second or third-rate power, would ensure that blissful condition of ensured peace and rapid domestic development on socialistic lines, which is the dream of certain radical extremists, is to imagine a vain thing.

Our prosperity as a people and a nation depends chiefly on the success of our industries. For that success we must have not only a larger share of our own home market, but growing markets outside these shores. It is now manifest that the foreign protectionist countries will tend more and more to exclude us from 
their markets for the more higbly finished goods. If any fresh object-lesson were needed, the last French tariff would furnish it.

In the neutral markets of the world the rivalry of foreign manufacturing Powers with ourselves becomes steadily lieener. Moreover, it is probably only a matter of time before some of these markets themselves become protectionist.

The one remaining and the most rapidly expanding market to-day is that within the British Empire itself. To secure and maintain a preference in that market is not merely to obtain an advantage now, but to peg out claims for posterity in the last great field for modern British enterprise, the growing markets for the finished products of industry. Free Trade, within the British Empire, is impracticable now and probably for an indefinite period in the future. But preference, which at least lowers existing internal barriers, and thus promotes a freer trade, if not an actually Free Trade, within the Empire, may be made a potent influence for extending British trade.

Such a policy as this can only be carried out while the colonies remain colonies. Once they were independent, any motive or pretext for establishing such relations would be gone. Moreover, the warning uttered by Professor Seeley should be kept clearly in mind.

"But observe that a small state among small states is one thing, and a small state among large states quite another. Nothing is more delightful than to read of the bright days of Athens and Florence, but those bright days lasted only so long as the states with which Athens and Florence had to do were states on a similar scale of magnitude. Both states sank at once as soon as large country-states of consolidated strength grew up in their 
neighbourhood. The lustre of Athens grew pale as soon as Macedonia rose, and Charles V. speedily brought to an end the great days of Florence." 1

We live in an age of great federations. And the conclusion already forced upon us by a study of the modern history of the United States and Germany is that fiscal policy may be a great federal instrument. Further, that the policy which most tends to the prosperity and allround symmetrical development of a great federated state is that which gives the greatest unity of material interest and purpose to the individuals, and different political communities, comprising that state.

If a Zollverein within, and Protection withont, be not feasible for the British Empire, preference within and a moderate tariff without both are. And together they would not merely prove an immense centripetal federal force, but would embody the one policy calculated to partially secure and develop for us great growing markets outside these islands in the future. And it is these conditions which alone will increasingly retain and employ British capital and labour at home. Thus on merely economic as well as Imperial grounds, the federal instrument of preferential, that is freer trade within the Empire would appear to be the best instrument at our disposal to-day.

The whirligig of time brings many changes. Fiscal exactions from the colonies by the mother country brought about the American Revolution and American Independence. Fiscal concessions on both sides, it is now urged, would lead to closer union. One further argument in favour of this view remains to be considered. The converse of it, namely, that Free Trade, or the policy of laissez faire, would prove a potent instru-

${ }^{1}$ Expension of Englend, p. 349. 
ment for separation of the colonies from the Mother Country has been strongly held by various writers, including Cobden, and the anomalous conditions of to-day, under which Canada shows a disposition to make reciprocal trade treaties elsewhere, if they are not to be made with the mother country, would appear to confirm the accuracy of this view.

Cobden, like Bright, was a profound believer in and advocate of universal peace, and he held that "the Colonial Policy of Europe" had been the chief source of wars for a hundred and fifty years previously. On this account he evidently regarded colonies and the colonial system as evils to be got rid of as soon as possible. Thus the separation of the colonies from the mother country was regarded by the founders and promoters of Free Trade as a probable consequence, and even as one of the laudable objects of their policy. So infatuated were they with the idea of substituting a cosmopolitan and millennial society for a world of sordid national rivalries. Thus in a letter to Mr. Ashworth in 1842 Cobden says: "The colonial system, with all its dazzling appeals to the passions of the people, can never be got rid of except by the indirect process of Free Trade, which will gradually and imperceptibly loose the bands which unite our colonies to us by a mistaken notion of self-interest ". ${ }^{1}$

In Cobden's view Free Trade and Peace were to go hand in hand. "They are," he says in the same letter, "one and the same cause."

To discuss whether Free Trade in its only true, that is its cosmopolitan sense, the sense in which Cobden delighted to regard it and to theorise about it, would

'Morley's Life of Cobden, vol. ii., p. 230. 
really promote the interests of peace, is to discuss a set of hypothetical conditions which have not yet existed. It is possible that if the world were once so amiably constituted as to be content to establish the "dependence of countries one upon another," such a condition might tend to lessen the chances of conflict as effectually as the modern method of endeavouring to maintain a balance of power. But the disposition of nations has been in an entirely opposite direction. The colonies have not separated from the mother country any more than other States have adopted Free Trade. Foreign States have become more intensely national and protectionist, while the colonies under the influence of a similar spirit have developed nationalism, protection, and imperialism, coming closer to, rather than receding from, British federal union. No nation, except a Cobdenite England, desires to be at the mercy of another for the supply of essential commodities. No theory, not even the Free Trade theory, has been able to stem the torrent of iron-clad facts. The only security for any country to-day is the security of wealth combined with power. They are the best guarantee in the first place of peace, in the second place of security should war arise.

If misleading appeals to the prejudices of a people be an evil, it is the laissez-faire doctrinaires, and not the patriots, who stand condemned. Free Trade, peace societies, the Sermon on the Mount are no more able to ensure us peace, than the soft mists which gather at nightfall are able to defend our coasts. As Kipling has warned us, we are "neither children nor gods, but men in a world of men".

But however illusory his separatist ideal, there is no doubt Cobden was right when he regarded Free 
Trade as likely to further it so far as the colonies were concerned. The cold rigidity of a system which treats a colony precisely as a foreign country is not calculated in itself to inspire much sympathy. But cold, disintegrating and centrifugal as Free Trade in its influence on the colonies has been, and is, there have been forces still deeper and more abiding in the opposite direction. And whatever may be the ultimate political goal of civilised mankind, whether a cosmopolitan committee will or will not eventually control the destinies of humanity, in the meantime the tendency of the last fifty years has not been, as the laissez-faire schoolmen dreamed it would be, towards smaller political units, but more and more into vast Imperial, or more accurately federal, groups. If, therefore, any form of idealistic cosmopolitan unity is to be arrived at in the future, it apparently will be by a process of evolution through larger and larger political units, and not by the indefinite multiplication and ultimate coalescence of small ones.

Yet how distasteful was the idea of a larger Britain to the Cobdenite politician, how obscure to him was the real tendency of the age, and how utterly erroneous was his forecast, may be gathered from the lugubrious reflections of Cobden's great literary biographer, Lord Morley. In a review of Seeley's Expansion of England, published now a good many years ago, Lord Morley set himself to put what he evidently regarded as the too exuberant optimism of Professor Seeley into its proper place.

"History, it would seem," says Lord Morley, "can speak with two voices-even to disciples equally honest, industrious and competent. Twenty years ago there was a Regius Professor of History at Oxford. . . . He 
(Professor Gold win Smith) applied his mind especially to the colonial question and came to a conclusion directly opposed to that which commends itself to the Regius Professor of History at Cambridge (Professor Seeley). Since then a certain reaction has set in, which events will probably show to be superficial, but of which while it lasts Mr. Seeley's speculations will have the benefit." 1

Since the foregoing words were written another period of rather more than twenty years has elapsed. Yet has the reaction to which the writer refers proved so superficial? Has it passed away, or has it remained and developed? Which of the two professors, in the light of subsequent events, heard the true voice of historyProfessor Goldwin Smith, the Separatist, or Professor Seeley, the Federalist?

Perhaps it may be argued that the time is still too short to enable us to decide. Yet within that periodsince Professor Goldwin Smith wrote in 1865-Canada has, under the influence of the federal spirit, united into one dominion; Australia is a Commonwealth, and South Africa is on the eve of following in the steps of her great colonial sister States. Moreover, all of these great and thriving groups of colonies grant a preferential tariff to the mother country, with a view to strengthening the Imperial tie.

Is not the superficiality to which Lord Morley refers rather in his own view, than in the British federal sentiment which is here so manifest and so profound? But that we may do neither Lord Morley nor those insular Englishmen who think, or thought, with him any injustice, let us consider a little more explicitly certain specific predictions or misgivings to which he gave

${ }^{1}$ John Morley, Critical Miscellanies, 1887. 
utterance in this review, and see how they have stood the test of time.

In support of his dislike for the idea of a greater British world State, and his contempt for anything approaching an Imperial Federation, he says in the course of the Review :-

"What is the common bond that is to bring the colonies into a Federal Union?

"Is it possible to suppose that the Canadian lumberman and the Australian sheep-farmer will cheerfully become contributors to a Greater Britain fund for keeping Basutos, Pondos, Zulus quiet?

"Is there any reason to suppose that South Africa would contribute towards the maintenance of cruisers?

"No: we may depend upon it that it would be a mandat imperatif on every federal delegate not to vote a penny for any war, or preparation for war, that might arise from the direct or indirect interests of any colony but his own."

Let us consider how time has answered these questions.

If no Federal Union has been attained, the common bond that may yet achieve it has been revealed. Canadian lumbermen and Australian sheep-farmers have stood side by side, of their own free will, contributing funds, services, lives, to the British cause in South Africa. South Africa has, all her quarrels notwithstanding, contributed towards the maintenance of cruisers. As for the mandat imperatif, and the narrow, petty parochialism which Mr. Morley imagined every colonist to cherish, the deeds of colonists since these melancholy hypotheses were evolved have blown them to the winds. IVas ever a writer more utterly mistaken, or more totally misled, than this brilliant doctrinaire 
in his endeavour to estimate the real sentiments of his kinsmen in the colonies?

The moral is obvious. It is folly for any man, however astute or skilled a writer he may be, to suppose that from the depths of his library in London he is, without any knowledge at first hand, and with no personal contact with the colonies, in a position to divine their innermost heart better than they know it themselves. If some old god from Olympus had descended once more into the arena of mortals for the purpose of making one of them his sport, he could not have done so more effectually than by inspiring the lucubrations of Mr. Morley.

Such morbid pessimism might be left to die a natural death, were it not for the fact that it still lingers in the minds of many Englishmen. But Free Trade having once more failed to accomplish what its promoters anticipated, and not having separated the colonies from us, what is to be the policy of the future?

Professor Seeley appears to have heard the true voice of history; Professor Goldwin Smith and Mr. Morley the false one. The march of events has been forward towards Federation, not backwards to separation.

The federal spirit within the colonies themselves, which has served to unite Canada, Australia and South Africa, has already been referred to. That same spirit still reigns supreme and extends itself to the Empire, or British Federation, as a whole. What form of central federal government for certain purposes may eventually be evolved it is beyond the scope of this work to consider. But the forces that are drawing us inevitably and almost unconsciously towards a closer Federation are as deep and permanent as the flow of the Gulf Stream.

And first and foremost are to be accounted those move- 
ments for the Empire's defence which sent spontaneously troops to South Africa and contributions towards the navy.

From these patriotic and picturesque incidents we must now pass on to the more prosaic, but none the less powerful, movement towards preferential, commercial relations between the colonies and the mother country, which have already been partially put in force by certain colonies, and are now eagerly advocated not only in the colonies but in the mother country. What the Zollverein has done for Germany, and a similar policy for the United States, has already been discussed.

The question we now have to consider is whether a Zollverein would prove a federating instrument and an economic advantage to Great Britain and her colonies. A Zollverein or Customs Union as it exists in Germany is probably inexpedient and at least for the moment impracticable for the British Empire.

The impartial student of political economy, and more particularly of economic history in the past, will fully realise, as I have endeavoured to make it one of the objects of this book to demonstrate, that there is no such thing as any one economic formula with regard to the fiscal problem, which is universally applicable. Certain formulæ and "economic laws" propounded by the laissez-faire writers have already, in the opinion of most competent judges, induced a habit of mind and mode of thought which has exercised a disastrous influence upon the fiscal policy of Great Britain. In rejecting these formulæ and the free import policy which is their expression, it will therefore be wise to avoid falling into a similar error in the opposite direction.

At the outset it must be frankly recognised that our 
colonies differ widely in their fiscal systems, as well as in their products and in their capacities for developing manufacturing industries. In some colonies a measure of Protection is deemed essential to the development of certain industries, in others the industries are of such a character that at least for the present there are few or no directions in which protective duties would serve any useful purpose.

There are great colonies, such as Canada, in which Protection in several directions is exercising a marked effect in so developing and utilising the great and varied natural resources of the country as to establish and foster considerable manufacturing industries. There are other colonies, such as the South African group, where a deliberately protective policy can scarcely yet be said to have been indicated, and where it has not to any appreciable extent been adopted. While finally there are certain tropical colonies, whose products being almost entirely raw material, have no protective duties at all.

It perhaps scarcely needs pointing out that there are cases both in countries and colonies where the expediency of Protection in this or that industry becomes a question of the most careful weighing of the relative claims of consumer and producer. No Protection ever yet devised will convert a sterile island devoid of natural resources into a hive of manufacturing industry. And in a lesser degree Protection of an industry, to the development of which a country is but ill suited, is calculated to place an unwarrantable burden upon the consumer, and is entirely at variance with that scientific, discriminating Protection directed to the symmetrical development of a country, and duly weighing the claims of both producers and consumers, which has been brought 
to such a high degree of national utility in the United States and Germany.

It is, therefore, not difficult to realise why in various British colonies ruled by practical men of affairs and business, uninfluenced by academic pedantry, there should have grown up such a variety of fiscal arrangements-arrangements made only with consideration to the resources and requirements of each individual colony. But there is one common feature in the fiscal systems of the various British Colonies which is of interest and value from the preferential point of view. They all derive revenue from the taxation of imports.

Where the tax is levied purely for revenue purposes, it is as a rule fairly uniform on manufactured articles, being so much ad valorem on the articles imported. In nearly all the colonies in the great majority of cases these tariffs have no protective value for the reason that the colonies do not manufacture the articles tariffed. But where, for one reason or another, as the resources and enterprise of a colony develop, certain manufacturing industries are started, the tariffs originally levied for revenue purposes come to have a certain protective value. As these industries advance the tariffs on the particular articles manufactured may or may not be increased so as to enhance their protective effect. The course eventually taken in this respect is determined by what the government of the colony consider expedient in the ultimate material and economic interests of the colony concerned, and not in deference to any blind adherence to the doctrines either of Free Trade or Protection.

Having a set of tariffs already in existence it has thus been comparatively easy for the self-governing colonies to extend to the mother country a certain measure of preference. 
On the other hand, although Great Britain has excessive tariffs on a limited number of imported articles, such as tea, coffee, sugar and tobacco-on which reductions might be made in favour of certain colonies-she has not as yet any genéral system of tariffs which would enable her to arrange a comprehensive system of preference applicable to all her colonies. In the case of manufactured competitive articles enough has already been said to show that what, even such rigid free traders as Mill admit, may be politic in the case of infant industries, would also appear to be called for in the case - to extend the metaphor-of certain injured industries. Such a degree of Protection would place the British manufacturer on level terms with his foreign rival and prevent him from unfair competition.

But in the policy of closer commercial union with the colonies we have additional objects to serve, and a somewhat different set of problems and conditions to consider. The advocates of this policy desire to serve the cause of Imperial consolidation, and at the same time to secure the advantage of preferential treatment in the most important set of markets now open to the world. It is thus both an Imperial and economic problem, and it is urged that both objects may be simultaneously served with advantage not only to the Imperial fabric, but also to the industries and commerce of the colonies and mother country.

The effort to promote this policy did not begin with the present Tariff Reform movement, although the powerful, disinterested and eloquent advocacy of Mr. Chamberlain, and the energetic campaign of the Tariff Reform League, have given it a weight which it never before possessed. Since the fair trade agitation of the early eighties, when a gallant attempt by Sir Howard 
Vincent and his colleagues was made to direct attention to the necessity of fiscal change, no less than three proposals have been made at different times, intended to give effect to the policy of colonial preference.

I. The first proposal was that of a Zollverein in its full and true sense, that is a Zollverein or Customs Union establishing complete Free Trade within the Empire, and a protective tariff against foreign countries.

Unfortunately, whether or no such a policy might have been expedient fifty years ago, it is on many grounds impracticable to-day. In the first place, the colonies have embarlsed on industries which are already in competition, not only with foreign but with British industries. These infant industries they cannot-at least at present-afford to expose to the level competition of British industries, without the prospect of seeing them seriously injured, if not crushed. Moreover, as already pointed out, the revenue is derived in the colonies chiefly from the customs, and to change their whole system of taxation would involve very considerable difficulties. On these and other grounds then the proposal of a Zollverein is at present impracticable for the British Empire.

II. The second proposal-a modification of the Zollverein system-is of special interest, inasmuch as it was made by a distinguished Dutch politician in South Africa, $\mathrm{Mr}$. Hofmeyer, who was selected by the Cape Colony to represent that country at the Colonial Conference held in 1887 .

The subject which Mr. Hofmeyer introduced to the conference for discussion was "The feasibility of promoting a closer union between the various parts of the British Empire by means of an Imperial tariff of customs, to be levied independently of the duties payable under existing tariffs, on goods entering the Empire from 
abroad, the revenue derived from such tariff to be devoted to the general defence of the Empire ". 1

In opening the discussion, Mr. Hofmeyer said :-

"I have taken this matter in hand with two objects: to promote the union of the Empire, and at the same time to obtain revenue for purposes of general defence. Everybody will acknowledge that the British Empire is the most unique that the world has ever seen. It is spread all over the globe, I may say piecemeal all over the globe, the different parts being separated by thousands of miles of sea or of foreign territory. In an Empire of such a nature one must expect that territorialism will arise, that local interests will make themselves felt, and that those local interests will act as disintegrating tendencies."

As an enunciation of Imperial policy this utterance has peculiar weight and interest as coming from a South African colonist of Dutch descent. The speaker then went on to point out that Protection would tend to develop in the colonies, but he added: "I aim at something that shall supply a cohesive force to the Empire, and shall at the same time provide revenue for defensive purposes. It may even be that in the course of years this system may, instead of providing a protective tariff, lead to absolute Free Trade as between the mother country and the colonies. If the various representatives of the colonies and of the Empire jointly should agree that there should be only one tariff, an Imperial tariff, and no local tariffs, you would have a Zollverein which involves perfect Free Trade between the various parts of the Empire." 2

This proposal was not accepted, but it marks an im-

${ }^{1}$ Proceedings of the Colonial Conference, 1887. (C. 5091.)

${ }^{2}$ Tbid., 1887. (C. 5091.) 
portant step in Imperial evolution, and Mr. Hofmeyer's warm advocacy of the measure was well described by one of the delegates, an Australian Premier, Mr. Service, as a "noble speech".

III. The third, and most important, proposal for closer commercial union with the colonies is that brought forward by $\mathrm{Mr}$. Chamberlain. It is a somewhat wider application of Mr. Hofmeyer's proposal and is based on mutual preferential arrangement in the customs tariffs between the mother country and the colonies, as against foreign countries. Such a policy as this, as already pointed out, has the advantage of being quite compatible with existing colonial fiscal arrangements, as all that is necessary for the colonies to do is either to lower existing duties in favour of Great Britain, or to raise them as against foreign imports. And such measures have already been taken in the case of all the great self-governing colonies of Canada, Australia, South Africa and New Zealand.

At the present time the fiscal system of India remains rigidly, and even remarkably, adherent to the theory of Free Trade, though in some respects the system in vogue can hardly be described as consistent with the doctrines of laissez faire. Next to America, India is the largest cotton-producing country in the world. She naturally aspires to manufacture a large portion of the cotton fabrics necessary to her own requirements. Yet under Lord Elgin, in opposition to the whole of India, an excise duty on cotton goods manufactured in India was imposed equivalent to the import duty. This step was taken avowedly in order that the Lancashire cotton manufacturers should be on precisely the same footing in India as the Indian manufacturers.

It is certainly not a policy that would be either pro- 
posed to, or accepted by, a self-governing colony, and it is strongly objected to in India. At the last Madras Industrial Conference a resolution recording an emphatic protest against the continuance of the excise duty on Indian mill-made cloth as an unjust and unnecessary impost, and urging its removal without delay, was unanim.ously carried. ${ }^{1}$ The Indian advocates of Protection point out with perfect justice that the present excise duty on cotton manufactured goods is a concession not only to free-trading England but also to protectionist Germany and other protectionist countries. India is thus compelled to submit her infant industries not only to the unchecked competition of free traders, but to that of foreign protectionists.

On the other hand Great Britain still has heavy duties on tea, coffee and tobacco, raw materials imported from India. The position does, therefore, appear to be capable of most beneficial adjustment on preferential lines advantageous both to India and Great Britain.

A repeal of the cotton import duty on British goods, and also of the excise, on the one hand, and the abolition, or at least diminution of all duties on Indian products sent to this country on the other, would remove a serious cause of irritation, and at the same time bring India and Great Britain into still closer trade relationship. Such an arrangement, so far as applicable, might equally well be made as between India and the self-governing colonies, and by this means India would be brought into the scheme of general Imperial preference.

In the case of the United Kingdom and the self-governing colonies certain difficulties present themselves. The chief one is that the products sent to the United Kingdom from the colonies are principally raw materials,

${ }^{1}$ The Times, 24th May, 1909. 
grain and meat. Thus from Canada the principal exports are grain, meat and timber; from Australia grain, meat and wool; and from South Africa wool, gold and diamonds.

None of these products are at present taxed. The policy of preference will therefore involve the imposition of a light tariff on some of them which come from foreign countries. Such protective advantage as might be obtained under this arrangement would be extended to the Empire as a whole, and thus be extended to a large body of competing producers, which would be sufficient to prevent any appreciable rise in prices. Mr. Chamberlain, in his great public campaign on behalf of tariff reform, has urged that raw materials such as wool and wood should not be taxed, but that small taxes on foreign grain, meat and dairy produce would be sufficient to give an appreciable preferential treatment to the colonies.

Around the whole of this question for some years past political controversy has unfortunately been raging, tending in many instances rather to obscure than to elucidate the questions at issue. To traverse all the various considerations which have been urged for and against any preferential arrangements would exceed the contents of any one volume, but one particularly prejudiced mode of attack on such preferential proposals as have been put forward calls for some examination.

The proposed taxes on foreign corn and flour are denounced as food taxes, and when it is pointed out in reply that taxes on sugar, tea, coffee and tobacco of a very heavy character already exist, and that it is proposed to diminish these to an extent at least sufficient to compensate for any enhancement of price which could conceivably be brought about by the moderate 
duty proposed on corn, and also, if imposed, on meat and dairy produce, the rejoinder is made that tea, sugar, coffee and tobacco are the luxuries, or the comforts of the poor, whereas bread and meat are necessities. An argument such as this is splitting hairs, and cannot be allowed to prejudice a great cause. Tea and sugar are to-day consumed in practically every household, and regarding these articles as food, it may fairly be stated that the amount of the food budget will not be increased by the changes proposed.

In the first place the extent, if any, to which a $2 \mathrm{~s}$. duty on foreign corn and a 5 per cent. duty on foreign meat and dairy produce would increase the price of these articles to the consumers in Great Britain is problematical. As they are all largely produced in Great Britain and the colonies it is, as already demonstrated, perfectly obvious that the price of these commodities, if increased at all, would not be increased to the full amount of the duties imposed (vide above, p. 40). But admitting for the sake of argument that some increase in price did occur, it is quite certain that with such heavy duties as those on tea, sugar, coffee and tobacco, to deal with it would be perfectly easy to more than compensate for such increase by a reduction on these articles.

Conditions with regard to existing taxation on articles of daily consumption, being as they are, such phrases as "free food" and "food taxes," tend to obscure and prejudice fair judgment of the issue, and must be relegated to that baser sort of political controversy which so frequently endeavours to destroy a cause by distorting it. Nevertheless this form of distortion on this particular subject has been in the past, and doubtless will remain in the future, a formidable obstacle to the establishment 
of a scheme of preference on these lines. But once the proletariat realise, as the more intelligent portion of it already realises, that the objection is a prejudice based on misrepresentation or misapprehension, and not an economic reality, it will lose its force.

A piece of impartial testimony to the great value if not absolute necessity of commercial preference with the colonies in the near future is contained in a work by Füchs, a German Professor of Political, Economy, The Trade Policy of Great Britain and her Colonies since 1860. This work is an exhaustive and lucid study of this policy which well repays perusal, and the conclusions at which the author arrived, as far back as 1893, are of the greatest interest.

"On political grounds, England needs, now more than ever, to retain her great Colonial Empire. But, owing to the numerous and active centrifugal forces of to-day, this can only be done by a closer union. Such a union England must try to secure at any cost.

"For the rest, these political considerations are, in part at least and indirectly, of economic importance as well. We have seen ... to what an extent England is dependent, not only for her industry but also for the food supply of her people, on foreign trade, and on the undisturbed continuation of the same in time of war. The safe-guarding of this immense British trade, and especially the transport of grain, would be altogether impossible without the possession of all her naval bases and coaling stations in the different colonies. There is, besides, to be taken into account the safety of the yet more rapidly increasing colonial trade, the protection of which still rests wholly on the mother country with the exception of the small subsidy, lately contributed by 
Australia, to the fitting out of a squadron for Australian waters. The protection of the whole enormous trade of the British Empire is-and on this all experts agreevery far from adequate. To make it so, immense additional expenditure would be necessary, and this, if the present constitution of the Empire continues, would again fall solely on the home country, although the colonies, to a considerable extent, would share in the benefit. How great an advantage it would be if the supplies of grain came, wholly or preponderantly, from other parts of the Empire, and if England were almost independent of foreign countries for the food supply of her people, is evident, when we consider that to-day the greater part of the British grain supply comes from Russia and the United States, i.e., from the countries with which England has most political friction. And how war can quite suddenly cut off supplies from a foreign country has been clearly proved by the stoppage of the cotton export from the American States during the War of Secession-and this was not a war in which England herself was involved. In the same way, there is no doubt that any new continental war in which Russia was involved would have the most momentous effects on England's economic life. . . .

"It remains to be seen whether time will raise up to England a statesman who possesses clear-sightedness, courage, energy and tact enough to bring this question to a happy issue-a question which is of so much importance for the future of England, as well for her position among nations as for her trade. But it must be soon, or it will be for ever too late."

Since this was written there has been a considerable increase in the amount of corn obtained from the Argentine and the colonies. Political friction may also 
be said to have changed its site from time to time. But broadly speaking, the criticism of our Imperial organisation, or lack of organisation, is as applicable to-day as when this paragraph was written.

Further than that the statesman, Mr. Chamberlain, has arisen. Has he come too late?

Füchs also argues that if England had resorted to preferential arrangements with her colonies several years back, combined with a policy of retaliation, the moral effect might have been to compel foreign countries to moderate their extreme protective policy. In this way he believes the strong protectionist reaction since the early eighties would have been prevented from going so far.

If this view is accurate-and the whole of Füchs' book goes to indicate that it is so-it may also be very fairly asked whether at the present moment the anomalous position of free-importing Great Britain in the midst of a protectionist world is not really the greatest obstacle to a relaxation of the extreme protectionist policy on the part of foreign countries, whether in fact England is not the greatest obstacle to freer trade in the world. At present the markets of Great Britain herself are freely accessible to all the world; those in the colonies, until the recent measures of preference to the mother country were granted, were equally accessible. Foreign countries have thus had no inducement to offer Great Britain any special concessions. It is true she has received such advantages as exist, under the most-favourednation treatment, but as the treaties containing the clauses defining this treatment are drafted entirely in the interests of the foreign countries signatory to them and without reference to England's interests, they are of little value to England and have in no way mitigated the most stringent protective duties levied directly against 
British manufactures. It is only a country with tariffs who can dictate, or even suggest, terms effectively, and not till England has a tariff to negotiate with can she anticipate more considerate treatment.

Füchs' final words of advice to his fellow-countrymen must be recorded :-

"The first thing is to hinder the carrying out of the scheme of a British Imperial Tariff Union with differential duties against foreign countries, as this, naturally, would be a great misfortune to Germany; the next, to hold fast unconditionally to the clanses referred to in the tariff treaties with Belgium and the Zollverein; the third, to zealously cultivate trade relations with the British colonies, and so to create great interests in them which would be hostile to any such scheme."

Since this was written German trade relations with British Colonies have developed proportionately more rapidly than our own.

In a further preface to the English edition of his book published in 1905, after the Tariff Reform movement in England had been some time in existence, Professor Füchs thought it desirable to modify his estimate of what effect a preferential policy with our colonies would have on Germany. For various reasons he did not think the economic results would be so important or inimical to German interests as he had anticipated. And he further urges German and British co-operation. It is to be hoped that his countrymen have also read this amendment in favour of that friendly spirit in commercial rivalry which contributes to the successful conduct of both international and private business.

What, then, in conclusion, are the economic and Imperial advantages of the policy of Preference? They 
have already been incidentally referred to, but may be recapitulated.

Such a policy would stimulate and increase the purchases of the mother country from the colonies and of the colonies from the mother country.

It would gradually lessen the dependence of Great Britain upon foreign countries for her food supplies, and increase the interdependence of one part of the Empire upon another for all the necessary commodities of life.

In this way a strong federating influence would be exercised.

It would be hailed with the greatest approval by the colonies, who have already taken the first step in this direction by themselves granting a preference to the mother country.

Finally, it will be the last remaining piece of evidence necessary to demonstrate to the little England party within Great Britain, and to the world outside, that though the march of our progress may be slow, it is sure, and that the goal is not a number of isolated, independent, Anglo-Saxon units scattered about the world, but a federated world State of self-governing communities in which the objects shall be peace with honour and security, justice and liberty with prosperity, a world State in which England shall serve as the ancient metropolis, and the ocean as a mighty highway. 


\section{CHAPTER IX.}

\section{DEMOCRACY AND EMPIRE.}

The federal movement-Colonial nationalism-The French Canadians and Dutch South Africans-The spirit of local patriotism a strength, not a weakness-Empire and Liberty-The dual empire-Self-governing and governed-One democracy cannot dictate to another-Flammantia monic Mundi.

IN considering the ultimate possibilities of the federal movement at present occurring within the British Empire, there is one all-important factor in the problem which has to be taken into the most careful consideration. Can the British democracy be relied upon to take a sufficiently broad view of the requirements and advantages of this movement as to sink minor prejudices to the extent essential to its ultimate success?

Much ground will be gained when it is more clearly recognised that the ideal aimed at is not a new scheme of government in which the mother country is to take on fresh burdens and fresh responsibilities, but a form of alliance with other Anglo-Saxon democracies already governing themselves under the British flag. An alliance in which some of the burdens which we already bear will be shared rather than increased, and in which some of the responsibilities, especially with regard to defence and foreign relations, will also be shared.

In the democracies of Canada and South Africa it 145 
must be borne in mind that while British forms of government and British traditions of liberty, justice and security to life and property predominate, and while the peoples of these dominions are loyal to the British flag and the Imperial tie, they are by no means all of British descent. The European population of Canada is largely of French descent, and that of South Africa is largely Dutch. In both cases these races were, equally with the British, pioneers in founding these colonies. In both cases they have shared in the development and progress of these colonies and to-day they play a large and powerful part in their government. Their loyalty to the Crown is therefore chiefly expressed in their devotion to the land of their birth, rather than in that sentiment for the mother country which still subsists in the colonist of British race even though he may never have seen it.

This spirit of colonial nationalism-which has been so admirably studied and described by Mr. Richard Jebb ${ }^{1}$ -must therefore never be lost sight of or misunderstood. Moreover, it is not only in Canada and South Africa among the French and the Dutch that this sentiment of colonial nationalism obtains, it exists in equal strength in Australia.

At the Imperial Press Conference held at the Foreign Office in Downing Street in 1909 it was a young Australian who said "Colonialism is dead"-colonies are becoming daughter nations.

This spirit of local and even national independence and patriotism is an additional strength rather than a menace to Imperialism. United action for common purposes of defence in war, or of commerce in peace, combined with absolute freedom of national development,

${ }^{1}$ Studies in Colonial Nationalism. 
mark the course best calculated both to maintain and strengthen the Empire, and at the same time to satisfy the natural and legitimate aspirations of our French and Dutch, as well as of our British kinsmen overseas. Silently but unceasingly the powerful influence of preferential trade will do its work. And modern steamships, like mighty shuttles plying to and fro between the warp and the woof, the colonies and the mother country, bearing the golden thread of commerce, will weave the fabric of Federation and of Empire.

And if any British worker, only partially it may be apprehending the true nature of this modern world State, should resent the term of Empire as one inimical to democracy, let him realise that over this British Empire there reigns no despot, but that within its dominions Empire and Democracy are wedded, Empire and Liberty go hand in hand. Further, it is necessary to recognise that besides the great self-governing dominions of Canada, South Africa, Australia and New Zealand, there are also the Crown Colonies and India, standing on a different basis and in a different relation to the mother country. The British Empire of to-day is in fact a dual Empire, of which one section is self-governing, and the other, principally owing to the existence of large native races, is governed on lines in which the principle of self-government is only very partially applicable and extant. They have been distinguished as the self-governing and the dependent Empires.

It is only with the great self-governing communities that the problem of closer federal union for the present has to be considered. But the very consideration of it does at times appear to create confusion in the minds of certain politicians who argue that what is good for Australia or Canada must also be good for India. 'l'he 
political, like the fiscal problem, has to be judged in each individual case on its merits, and the attempt at a too broad generalisation results in fallacious conclusions with reference to both.

The results of British rule in India on bureaucratic and oligarchic lines have been too solid and substantial to justify any too reckless an interference with the existing machinery of Government, made in deference either to spasmodic agitation or to the abstractions of benevolent constitutional theorists entirely unacquainted with native races. In the same way the British Democracy must realise, with regard to questions of native policy which from time to time arise in South Africa and elsewhere, that they are essentially problems to be dealt with on the spot. One democracy cannot dictate to, much less govern, another. And once a community like that of the recently united South Africa has been granted a self-governing constitution it must be left to frame its own native policy without vexatious and continuous interference on the part of the British Colonial Office. Unwarranted action of this character only recently evoked an indignant protest from the Natal Premier.

The two great factors which will be supreme in the Federation of ourselves and our daughter States are mutual reciprocity in the field of commerce, mutual confidence in the field of political administration. It is not for us to say whether labour in the Transvaal shall be white, black or yellow, it is not for us to say whether a military demonstration and arrests by Natal forces within the Natal borders are or are not necessary. Mutual respect and confidence, indeed all the canons of justice and common sense, demand that, once selfgovernment be granted, the privileges of self-government shall remain unquestioned. 
Whenever the British voter feels tempted to agitate for a policy of interference in some colonial internal question let him bear in mind that by so doing he is endeavouring to override the privileges of fellow British voters, and that he violates every principle of that democratic form of government on the rights of which he is himself so emphatic.

Reference has already been made to the dread, statesmen of the type of Cobden or Lord Morley appear to have entertained, of the demoralising influence, and the danger, of what they regard as the dazzling character of the colonial system. Imperialism is in their minds of so vaunting a character that they fear it may o'erleap itself. The warning is surely a little out of date to-day when Democracy sits enfranchised and enthroned in all the great British Colonies.

But if there still be those who at times are tempted to set too much store by the Flammantia moenia Mandi, let them remember that there is also another and a nobler side to the picture.

One of the things which most rejoiced the heart of Cecil Rhodes was the growth of English violets on the site of Lobengula's kraal. Peaceful civilisation, in place of savage tyranny, in the heart of the wild. 



\section{APPENDIX.}

I.

STATE INSURANCE FOR WORKMEN IN GERMANY.

In the history of social progress there is, perhaps, no institution which has done more to protect mankind from those accidents of fortune which leave not only men, but women and children, destitute than that of the various forms of insurance.

Among the upper classes in civilised countries a system of insurance has now been in existence for many years, but among the working-classes, where the need is certainly not less, insurance has only hitherto been thoroughly and systematically organised in one country-Germany.

The system which has now been in force in that country for twenty years is of such a remarkable, and in many respects of so beneficent a character, that in November, 1902, I induced an influential deputation from the National Conference of Friendly Societies in England to accompany me to Germany and study the question on the spot. They received a cordial welcome both from State oflicials and fellow-workmen in Germany, and they have issued a most interesting report to the members of their societies on what they learnt there. There is no doubt that this system of workmen's insurance deserves a more careful study by the people of other countries than it has hitherto received.

The work of State insurance in Germany, to which the writer refers, was initiated by the message of the Emperor William I. to the Reichstag in November, 1881. This mes- 
sage, as communicated by the Chancellor, Prince Bismarck, may be cited here:-

"We consider it Our Imperial duty to impress upon the Reichstag the necessity of furthering the welfare of the working-people. We should review with increased satisfaction the manifold successes, with which the Lord has blessed Our reign, could we carry with us to the grave the consciousness of having given our country an additional and lasting assurance of Internal peace, and the conviction that We have rendered the needy that assistance to which they are justly entitled. Our efforts in this direction are certain of the approval of all the federate Governments, and We confidently rely on the support of the Reichstag, without distinction of parties. In order to realise these views a Bill for the Insurance of Workmen against industrial accidents will first of all be laid before you, after which a supplementary measure will be submitted providing for a general organisation of industrial Sick Relief Insurance. But likewise those who are disabled in consequence of old age or invalidity possess a well-founded claim to a more ample relief on the part of the State than they have hitherto enjoyed. To devise the fittest ways and means for making such provision, however difficult, is one of the highest obligations of every community based on the moral foundations of Christianity. A more intimate connection with the actual capabilities of the people, and a mode of turning these oapabilities to account in corporate associations, under the patronage and with the aid of the State, will, We trust, develop a scheme to solve which the State alone would prove unequal."

Under the system which has been evolved out of this Imperial mandate, the working-man, incapacitated from work by sickness, accident, infirmity or old age, has a legal right to a measure of provision, both for himself and family, which save him from being compelled to rely upon public charity.

The means by which this end has been obtained require some description. They are based upon compulsory insurance 
on the part of the working-man and his employer, under a system of administration in which the insured are represented. Under this system there are three forms of insurance :-

(1) Accident.

(2) Sickness.

(3) Invalidity and Old Age.

\section{Accident Insurance.}

(1) In this branch the premiums are entirely paid by the employers, and in cases of death resulting from an accident an allowance is made to the survivors from the day of death. In the case of widows and children this allowance is 50 per cent. of the yearly earnings, or in the case of dependent parents 20 per cent.

For the first thirteen weeks an injured man is supported out of the Sick Fund (No. 2), and if by that time he is not sufficiently recovered to resume work he receives an allowance, during disablement, up to 60 per cent. of yearly earnings, or free hospital treatment during the whole cure and an allowance for the family.

This accident insurance is extended to work-people engaged in industry or agriculture, to officials whose salaries do not exceed $£ 100$ a year, and to small employers.

The employers are united in trade associations and contribute to the insurance funds proportionately to the wages paid or to the number of hands employed, as well as to the risk of accident in the various occupations.

\section{Insurance Against Sickness.}

(2) In this class the workman pays two-thirds of the premium and the employer one-third. In case of sickness the allowance is made for thirteen weeks, or the sick man receives free hospital treatment and half the sick pay for the support of the family.

Similar relief is provided for women in child-bed for four 
weeks; and in case of death the funeral expenses (twenty times the daily wages) are paid.

The sickness insurance is managed by local sick associations, of which there are a number of organised branches.

One of the many indirect advantages of this system is that not only is the man paid, but feeling that his family are provided for, this knowledge prevents him from leaving the hospital too soon, and he enjoys the first essential to recovery - from any form of accident or sickness - a mind at rest.

\section{Insurance against Infirmity and OLd Age.}

(3) This fund is contributed to conjointly by the Empire, the employers, and the employed. The Empire contribute to each aunuity the fixed amount of 50 marks ( $£ 210$ s.) per annum, and pays as well the contribution of the workman himself while serving in the army or navy. The employer and the employed contribute equally and in proportion to the wages earned.

The payment of these contributions is really made by the employer, who affixes stamps to the card of the insured weekly. The stamps are issued by the Imperial Insurance Department, and in paying the wages of the employed the employers are entitled to deduct the workman's share of these contributions.

The charges of the entire workman's insurance on the year's average is as follows:-

\begin{tabular}{|c|c|c|c|c|}
\hline & $\begin{array}{c}\text { Employers' } \\
\text { marks. }\end{array}$ & $\begin{array}{c}\text { Employed } \\
\text { marks. }\end{array}$ & $\begin{array}{l}\text { Empire } \\
\text { marks. }\end{array}$ & $\begin{array}{l}\text { Total } \\
\text { marks. }\end{array}$ \\
\hline $\begin{array}{l}\text { Sick insurance. } \\
\text { Accident insurance. } \\
\text { Invalidity insurance }\end{array}$ & $\begin{array}{l}5 \cdot 15 \\
6 \cdot 08 \\
4 \cdot 65\end{array}$ & $\frac{10 \cdot 30}{4 \cdot 6.5}$ & $\frac{-}{2 \cdot 88}$ & $\begin{array}{r}15 \cdot 45 \\
6 \cdot 08 \\
12 \cdot 18\end{array}$ \\
\hline Total. & $15 \cdot 88$ & $14: 05$ & $2 \cdot 88$ & $33 \cdot 71$ \\
\hline
\end{tabular}


From this it will be seen that the workman actually does not pay the half of the whole charges. By the workmen's insurance he gets back considerably more in compensation than he pays in the form of contributions.

These three branches of National State Insurance supplement one another and form a complete organisation which goes far to relieve distress thrown upon the entire family in the case of sickness, incapacity for work, or death of a workman.

The effect of this organisation is more far-reaching even than this. The social status of the workman is raised to a higher plane than that attained perhaps in any other State. In place of dependence on almsgiving, the workman claims as a right from the State that relief, in case of sickness, for himself and family, which the State has helped him to purchase and not left him to beg.

Out of the capital funds of the workmen's insurance, grants by way of advance are made for improving the dwellings of workmen and for supporting every improvement of public interest. In the Guide to the Workmen's Insurance of the German Empire, written in 1901, Dr. Zacher writes:-

"Now already one million marks are expended daily in Germany for this branch of provision for workmen alone, whilst the accumulated funds already exceed one milliard marks $(£ 50,000,000), 100$ millions $(£ 5,000,000)$ of which have been spent in constructing workmen's dwellings and special establishments for sick, injured, invalided and convalescent work-people, public baths, and the like institutions for the benefit of the working-classes. As, however, the circumstances which tend to disturb the good relations between employers and employed are everywhere much the same, the hope is natural and well justified, that the consideration and forethought which the German labourers owe to the beneficent sacrifice of their employers will find an echo in other cirilised countries, for the welfare of the human race and the consolidation of social peace and concord." 
The workmen's insurance has also done much to improve the general conditions of life for the workman and his people, and the consideration that, in case of sickness and incapacity for work, he is entitled to an indemnity from the insurance funds, largely allays anxiety. The policy on the part of the controllers of the fund is to prevent danger from sickness and accident. And this policy, which has inspired much of the work of the State Sick Insurance Department (Reichsversicherungsamt), is described by a short formula constantly quoted, "The Prevention of Invalidity". As sickness immediately makes a call upon the common fund the various local branches, or sick clubs, not only address themselves to restoring the sick to health, but endeavour to prevent by every hygienic and and other beneficent measure the occurrence of disease. Thus by the aid of the State Sick Insurance Department, millions of publications, such as the Tuberkulose-Merkblatt, were distributed among the working-classes and to the officers of the sick clubs and unions, and they have attracted much interest. Statistics of the sick and invalided were compiled, and showed that of all men working in mining, metallurgy, industry and building who become invalided at the age of thirty, more than half suffer from consumption. The proportion among workmen was much the same.

The result of these facts led the department to issue a circular calling attention to the importance of the crusade against consumption. The three great unions, engaged under the active patronage of the Empress in combating tuberculosis, to which the Workmen's Insurance Department and other insurance institutions belonged, w $ə$ re much impressed, and proceeded to take up the work, especially the provision of sanatoria for consumptives throughout Germany. 
II.

THE NAVIGATION ACT.

(i) The following are the principal dispositions of this Act as given by Adam Smith: "All ships, of which the owners, masters and three-fourths of the mariners are not British subjects, are prohibited, upon pain of forfeiting ship and cargo, from trading to the British settlements and plantations, or from being employed in the coasting trade of Great Britain.

"(ii) A great variety of the most bulky articles of importation can be brought into Great Britain only, either in such ships as are above described, or in ships of the country where those goods are produced, and of which the owners, masters and three-fourths of the mariners are of that particular country; and when imported in even ships of this latter kind they are subject to double aliens duty. If imported in ships of any other country, the penalty is forfeiture of ship and goods. When this Act was made the Dutch were, what they still are, the great carriers of Europe, and by this regulation they were entirely excluded from being the carrier's to Great Britain, or from importing to us the goods from any other European country.

"(iii) A great variety of the most bulky articles of importation are prohibited from being imported, even in British ships, from any country but that in which they are produced, under pain of forfeiting ship and cargo. This regulation too was probably intended against the Dutch. Holland was then, as now, the great emporium for all European goods, and by this 
regulation British ships were hindered from loading in Holland the goods of any other European country.

"(iv) Salt fish of all kinds, whale-fins, whale-bone, oil and blubber, not caught by and cured on board British vessels, when imported into Great Britain, are subjected to double aliens duty. The Dutch, as they still are the principal, were then the only fishers in Europe that attempted to supply foreign nations with fish. By this regulation a very heavy burden was laid upon their supplying Great Britain.

"When the Act of Navigation was made, though England and Holland were not actually at war', the most violent animosity subsisted between the two nations. It had begun during the Government of the Long Parliament, which first framed this Act, and it broke out soon after in the Dutch Wars during that of the Protector and of Charles II. It is not impossible, therefore, that some of the regulations of this famous Act may have proceeded from national animosity. They are as wise, however, as if they had all been dictated by the most deliberate wisdom. National animosity at that particular time aimed at the very same object which the most deliberate wisdom would have recommended, the diminution of the naval power of Holland, the only naval power which could endanger the security of England." 


\section{INDEX.}

Agriculture, injured by free im- Cocoa, duty on, 16. ports, 20 .

- statistics of, 20.

- people employed in, 21.

America and Protection, 47.

Ashley, W. J., 3.

Austria, war with Prussia, 71.

Avebury, Lord, on imports and exports, $27,34,35$.

- on protection in America, 56, 66.

Bentham, 11.

Bismarck, on Free Trade in Germany, 80 .

- his constructive policy, 83 .

British Empire, 120.

- - the two Empires, 147.

Buckle, on Adam Smith, 97.

Cattle, number of, in United Kingdom, 21.

Chamberlain, Right Hon. Joseph, his commission, statistics of, $20,21$.

- his Tariff Reform proposals, 136.

Churchill, Mr., on foreign investments, 112.

Cobden, on free importation of corn, 18.

- on corn laws, 18.

- on natural protection, 19.

- conviction on world's adopting Free Trade, 22.

- Club, abstractions of, 57.

- his mission abroad, 101.

- on separation of Colonies, 123.

- on universal peace, 124.

- protection of, 16.

Colonial Conference, on import duties, 41.

- nationalism, 146.

Colonies, the, 120.

Commission of Inland Revenue, report, 35 .

Conquerors, the, 5 .

Continental Blockade, the, 77 .

Co-partnership system, 8.

Corn crops in United Kingdom, 20.

Corn Laws, 12, 13, 98.

Cosmopolitical economy, 4, 5 .

Cosmopolitanism, 5, 126.

Cotton industry, origin of, in Lancashire, 90.

- - progress of, under free imports, 107.

- - persons employed in, 108.

Crœsus, advice from Solon, 3 .

Crops in United Kingdom, 20.

- acreage under, 20.

Crown Colonies, 147.

Cunningham, growth of English industry, 86.

Deakin, on import duties in Aus. tralia, 41.

Democracy and Empire, 145.

Depopulation of villages, 22 .

Dupont de Nemours, 4.

Economic laws, 6.

- formulæ, 6 .

- system of, Jevons on, 7.

- men, 9, 58.

- infallibility, 17.

- fallacies, ch. iii., 27. 
Economic truths, 39.

Edward III., taxes in time of, 88. Elizabeth, taxes in time of, 88 .

Emigration, rate of, from England and Germany, 82.

Exports, balance imports, 27.

- the suggestio falsi, 32 .

- trade of principal countries, 81.

- per head, 99.

- of manufactured goods, 102.

Farrer, Lord, on imports and exports, 29.

- - on Fair Trade, 36.

Federalism, 5.

Federation, fiscal system as federal instrument, 65.

Fiscal Blue Book, on imports and exports, 29.

Food taxes, 138.

Foreign investments as sources of importing power, 30 .

- - extent of, 35.

- - nature of, 111.

Free Trade, 12.

- - principles of, 16.

- MrKinley on, 23.

- - miscalculations, 24.

- - universal, 25.

- - in Germany, 77, 80.

- - Bismarck on, 80.

- - Great Britain's era of, first half, 95 .

- - Great Britain's era of, second half, 102.

- - policy of England defined, 96.

- - review of, in Great Britain, 118.

- - Bismarck on, in England, 119.

- - disintegrating influence of, 124.

French economists, 3.

Füchs, Professor, on trade policy of Great Britain and Colonies, 140.

German institutions, how far applicable in Great Britain, 85. Germany, her Customs Union, 68.

- modern, 68, 70.
Germany, Zollverein in, 73.

- Manufacturers' Union in, 78.

- progress under Zollverein, 81.

- exports of, 81 .

- unemployment in, 82.

- emigration from, 82.

-- Economic Union of, 83.

- State insurance for workmen, $84,157$.

- British trade with, 115.

Gournay, 4.

Great Britain before Free Trade, 86 .

Hamilton, Alexander, 47.

- problems before, 48 .

- report on manufactures, 49,51 .

- on protection of infant industries, 53.

- on symmetrical national development, 55 .

- his condition for Free Trade,58.

Hofmeyer, on an Imperial Tariff, 134.

Holy Roman Empire, 68.

- - Voltaire on, 69.

- - Bryce on, 69.

- - North Germans on, 70.

Hume, on woollen industry, 87.

Imperialism, 146.

Import duties, burden of, 40, 43 .

- - in Australia, 41.

Importing power, sources of, 30 .

Tmports, balance exports, 27.

- of manufactured goods, 102.

India, trade with, in eighteenth century, 90.

- Free Trade in, 136.

- position in British Empire, 147.

Infant industries, $53,94$.

Injured industries, 54, 94.

Insurance, State insurance for workmen in Germany, 84, 151.

James I., taxes in time of, 89.

- woollen industry in time of, 89.

Jebb, Richard, on Colonial Nationalism, 146.

Jevons, on system of Economics, 7. 
Jones, Riohard, his criticism of Napoleon, on industry, 73. Ricardo, 9.

Labour, 15.

- protected, 15.

- sweated, 16.

- fate of, when displaced, 38.

Labourer, share in profit, 8 .

Laissez faire, ch. ii., 11.

- - origin of term, 4.

- - policy defined, 4.

- - principles and doctrines of, 11.

- - limits of the principle, 13.

Lawrence, Sir Joseph, on foreign investments, 35.

Lincoln, on tariffs, 61.

List, on national system of Political Economy, 3, 74.

- on productive power, 3,91 .

- on wealth, 3.

- views contrasted with those of Adam Smith, 3.

- visit to America, 74.

- on Zollverein, 74.

- on British policy, 75 .

- on power, 75.

- on England's position, 76.

- his predictions verified, $76,83$.

- on Free Trade in Germany, 77.

- and Mill on America compared, 79.

Live stock in United Kingdom, 20.

Marshall, Professor, on change of employment, 38.

- - on Economic Truths, 39.

McKinley, on Free Trade, 23, 63.

Merchant Shipping Act, 93.

Methuen Treaty, results of, 90 .

Mill, John Stuart, definition of Political Economy, 1.

- Jevons on, 7.

- Limits of laissez-faire principle, 13.

- thought Protection doomed, 23.

- on imports and exports, 28.

Morley, Lord, on separation of the Colonies, 126.

Mosely, memorandum on American tariffs, 60 .

Motor industry, 103.

- his Continental Blockade, 77.

Natural wages, 7.

- protection, 19, 21, 99.

- - eliminated, 22.

Navigation Act (see also Appendix), 2,157 .

- - views of Adam Smith and List on, 92 .

Norman period, 87.

Oliver, book on Hamilton, 48.

Patents Act, 17.

Physical laws, 6.

Physiocratie, 4.

Pigs, number in United Kingdom, 21.

Political Economy, as defined by John Stuart Mill, 1.

- - defined, 5 .

- evolution, 5.

Portugal, trade with in XVIIIth century, 90.

Preference, 123, 134.

- advantages of, 143.

Production, natural conditions of, 24.

Productive power, 3.

- - " a complex variable," 9.

Protection, natural, 19, 21, 99.

- in America, 47, 65.

- of infant industries, 53.

- of injured industries, 54 .

- in Great Britain, 88-94.

- in Colonies, 131.

Prussia, wars of, 71.

- product of Income Tax in, 82.

Quesnay, 4.

Raw cotton, world's consumption of, 25.

Restrictions on trade, 12.

Revenue taxes, 96.

Rhodes, Cecil, 149.

Ricardo, Jevons on, 7.

Ricardo-MIill Economics, 7.

Rogers, Thorold, on economic interpretation of history, 87.

Roland, Girondist minister, on trade restriction, 12. 
Seeley, Professor, on small estates, Unemployment in England and 122.

Seligman, Professor, 43.

Sheep, number in United Kingdom, 21.

Shipbuilding, 107.

Sidgwick, Professor, 43.

Smith, Adam, on laissez-faire, 4.

- on Navigation Act, 2,92 .

- his views contrasted with those of List, 3.

- on free importation of corn, 17.

- on exports and imports, 28.

Smith, Goldwin, Professor, 127.

Social Democrats in Germany, 84.

Socialism, in Germany, 84.

Solon, advice to Crœsus, 3.

Steel, world's production of, 25 .

Tariff Commission, Mr. Chamberlain's statistics of, 12, 20.

- memorandum in America, 60.

- compromise in America, 61.

- Lincoln on, 61.

- Commission of the United States, 62.

- the McKinley, 63.

- Reform League, 103.

- Reform Commission, 103.

- proposals considered, 118.

- - of Mr. Chamberlain, 136.

Unany, 82.

United States and Protection, 47.

- Confederation of, 49.

- Constitution of, 50 .

- memorandum on American tariffs, 60 .

- production of steel and raw cotton in, 65 .

- industrial progress of, 66 .

- exports from, 82 .

Von Hïnen on natural wages, 7.

Washington, 49.

Wealth of Nations, 2, 3.

- of England, 108.

- distinct from industry, 116.

Welsford, on strength of nations, 86.

Wheat cultivation in United Kingdom, 20.

Woollen industry in Great Britain, $87,89$.

- - under Free Imports, 105.

Workshop of the world, 26.

Zollverein, German, 3, 73.

— List on, 74.

- proposed for Colonies, 134. 
• 

UNIVERSITY OF CALIFORNIA LIBRARY

Los Angeles

This book is DUE on the last date stamped below.

Form L9-25m-9, $+7($ A.5618) 414

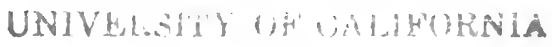

A $\mathrm{T}$

LOS ANGELES

LIBRARY 
